\title{
Price Transmission and Market Integration in Swiss Agricultural and Food Markets
}

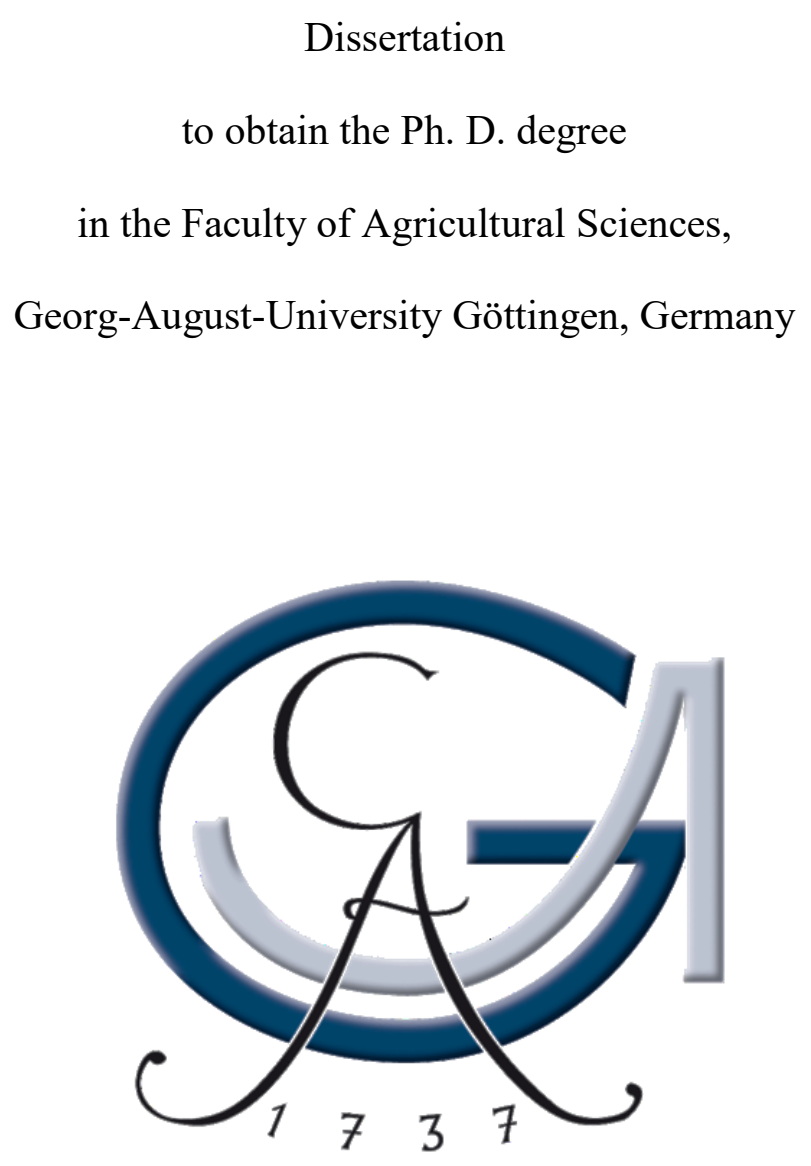

presented by

Judith Hillen

born in Neustadt an der Weinstrasse, Germany

Göttingen, September 2019 
1. Name of referee: Prof. Dr. Stephan von Cramon-Taubadel

2. Name of co-referee: Prof. Dr. Bernhard Brümmer

3. Name of $2^{\text {nd }}$ co-referee: Dr. Dr. habil. Stefan Mann

Date of dissertation: 14 November 2019 


\section{Acknowledgments}

I would like to thank Stephan von Cramon-Taubadel for accepting to supervise my thesis and for all the valuable advice and feedback. I am grateful to Stefan Mann for giving me so much freedom in choice of research topics and methods.

Moreover, I am very thankful to the staff of the Swiss Federal Office for Agriculture for providing access to so much data and for the insights into the "real" policy making process. Also, I want to thank my colleagues at Agroscope Tänikon for the interesting professional discussions and exchange of ideas, as well as for all the good times in and around the office. Finally, a big Dankeschön goes to my family - especially to Fabian, who supported me in more ways than one single person possibly can. 


\section{Table of contents}

$\underline{\text { Page }}$

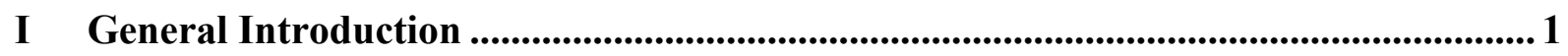

1 About Switzerland's agricultural and food markets ............................................. 1

2 Overview of the articles ................................................................................. 3

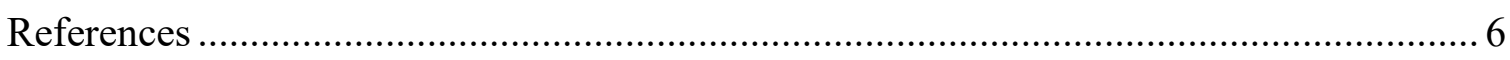

II Protecting the Swiss milk market from foreign price shocks: Public border protection vs. quality differentiation ..................................................................................... 10

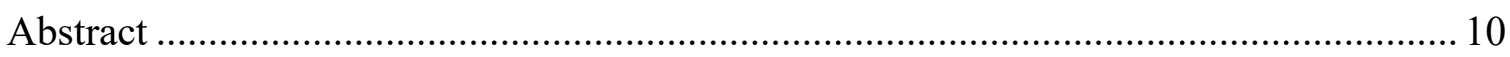

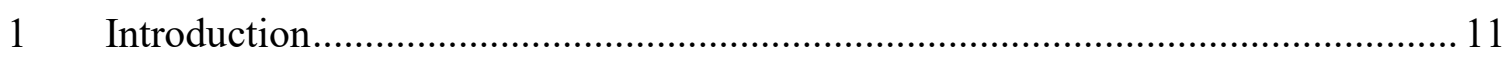

2 Characteristics of the Swiss Milk Market............................................................... 12

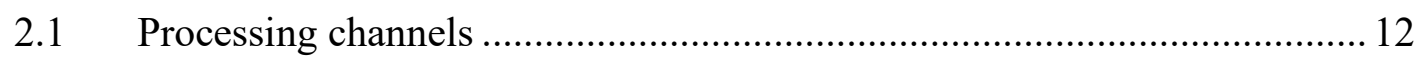

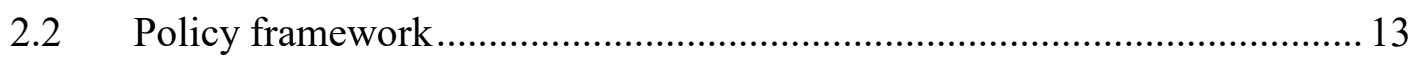

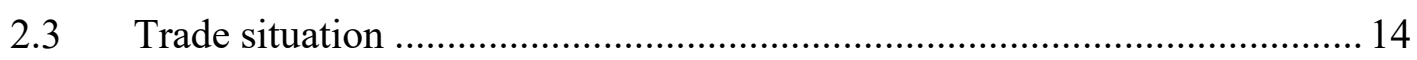

2.4 Product characteristics and differentiation............................................. 15

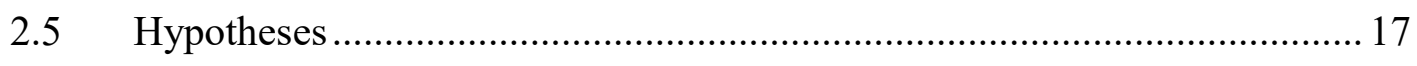

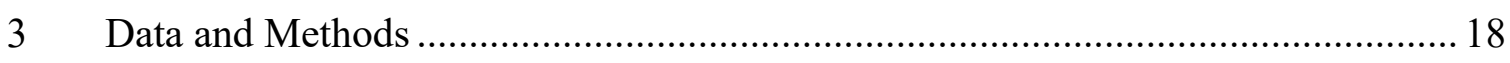

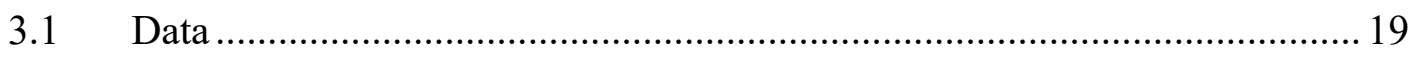

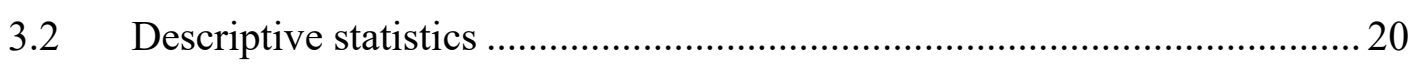

3.3 Individual testing for unit roots and structural breaks ............................. 22

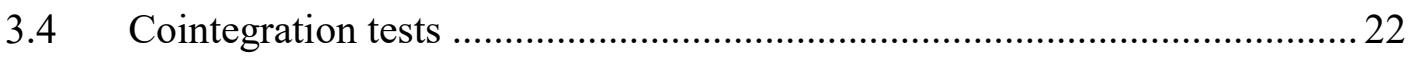

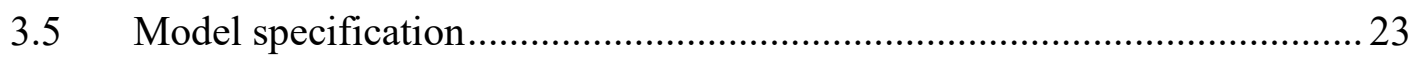

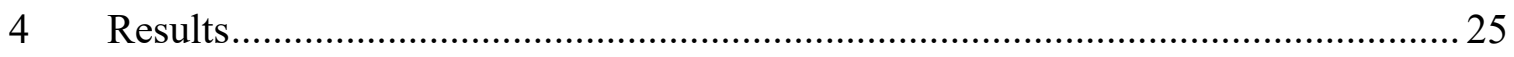

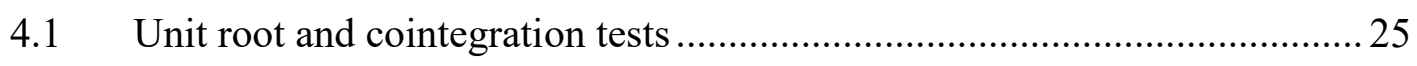

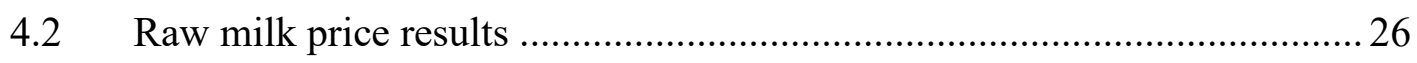

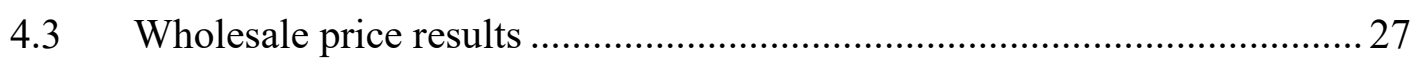

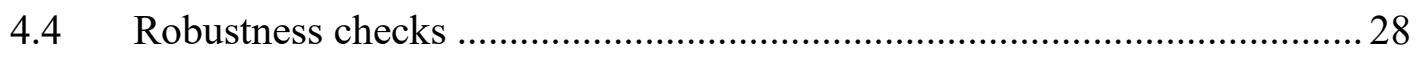

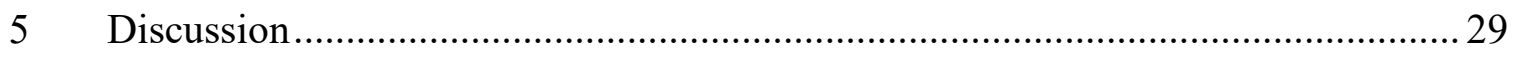

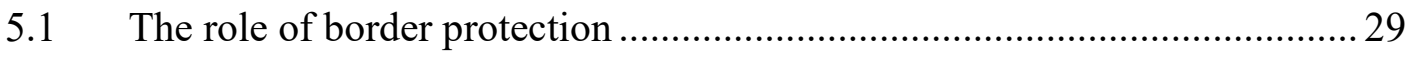

5.2 The role of qualitative product characteristics ......................................... 31

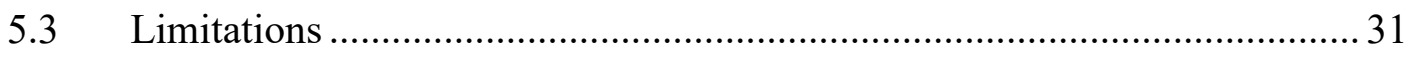

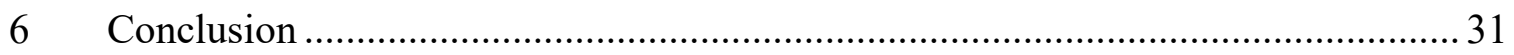

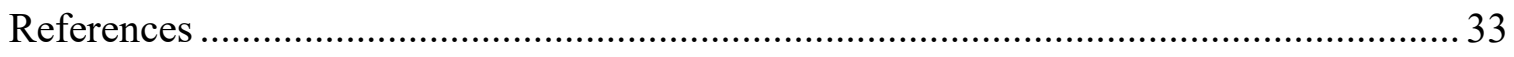

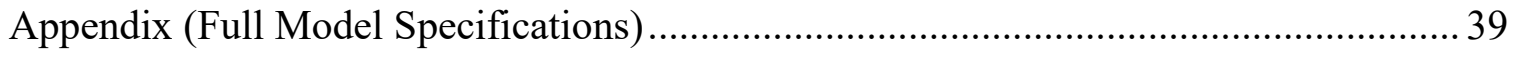


III Vertical Price Transmission in Swiss Dairy and Cheese Value Chains .47

Abstract 47

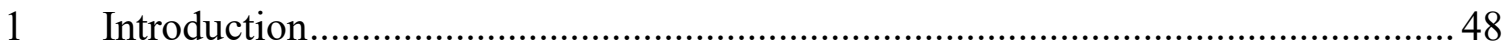

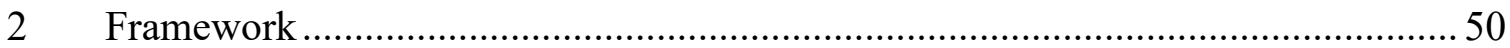

$2.1 \quad$ Structure of the Swiss milk market ................................................................ 50

2.2 Potential influence on vertical price transmission ................................... 51

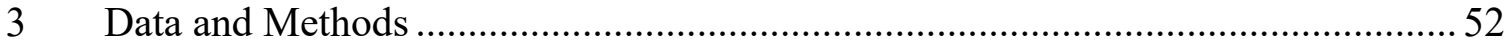

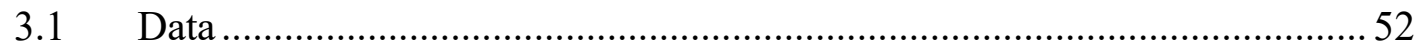

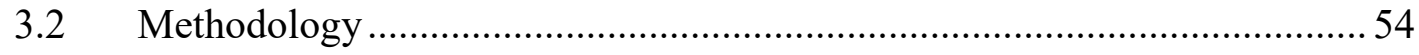

3.2.1 Unit root and cointegration tests ............................................... 54

3.2.2 VECM and VAR models ........................................................ 56

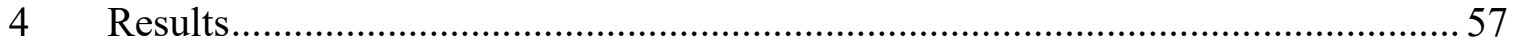

4.1 Unit root and cointegration test results .................................................. 57

$4.2 \quad$ Vector error correction model results ........................................................ 59

$4.3 \quad$ Vector autoregressive model results .......................................................... 61

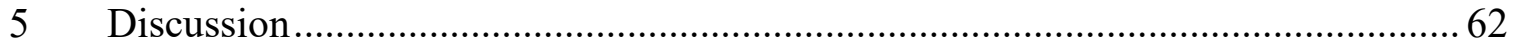

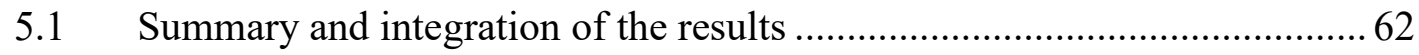

5.2 Potential reasons for low or weak price transmission................................. 64

5.2.1 Statistical properties of price series ............................................. 64

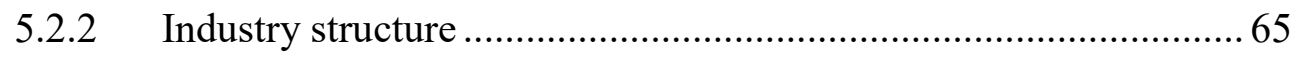

5.2.3 High income and cost level in Switzerland .................................. 66

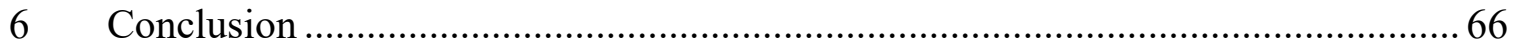

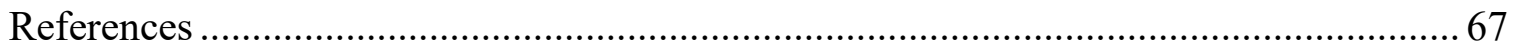

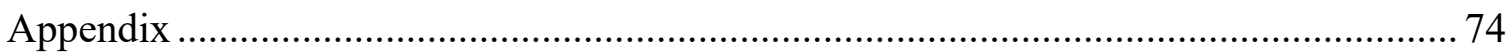

IV Market Integration and Market Efficiency under Seasonal Tariff Rate Quotas...... 81

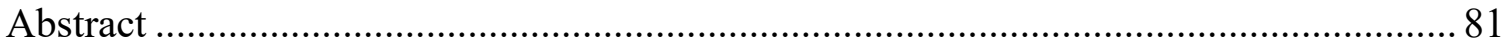

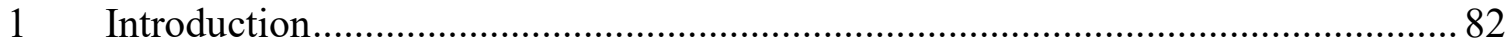

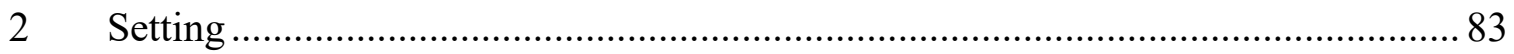

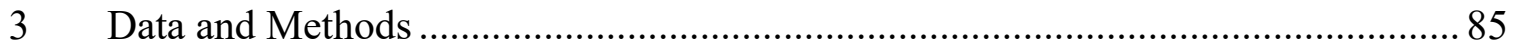

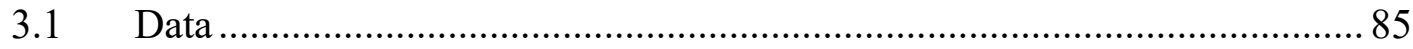

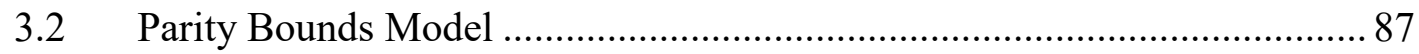

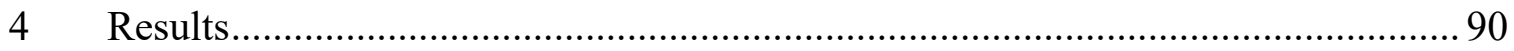

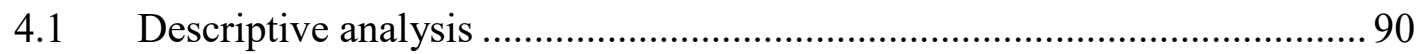

4.2 Parity bounds model estimation results ................................................... 92

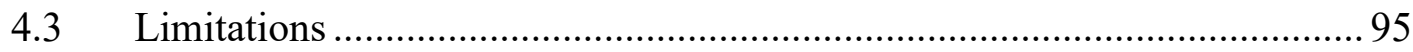

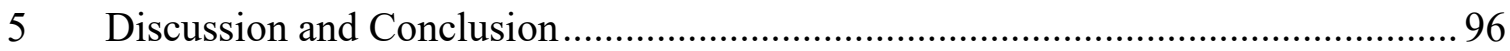




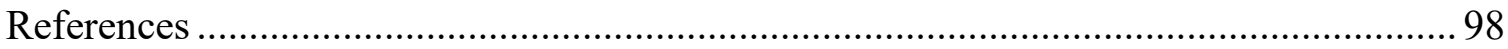

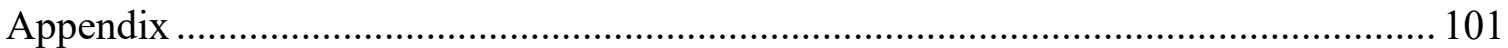

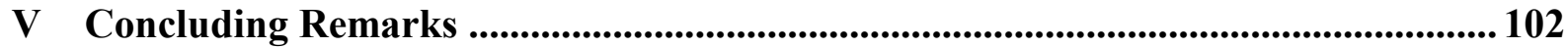

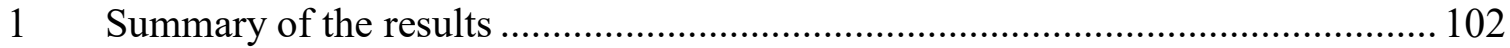

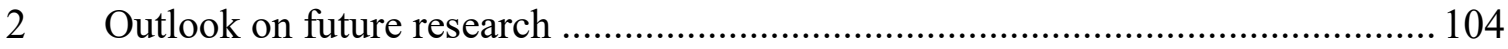

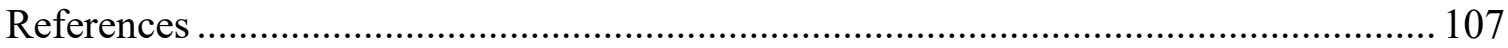

Curriculum Vitae ............................................................................................................................ 109 


\section{General Introduction}

This cumulative dissertation aims to contribute to a better understanding of price transmission and market integration in Swiss agricultural and food markets. It contains three articles dealing with quantitative analyses of market integration and spatial and vertical price transmission. This work contributes to an extensive strand of price transmission literature that analyzes how prices are passed on between markets, either spatially, i.e., between geographically separated markets, or vertically, i.e., between different stages of a processing chain (for recent reviews see, e.g., Lloyd 2017, von Cramon-Taubadel 2017). In this introduction, I argue why analyzing such interrelationships and dynamics of prices is particularly interesting in the case of Swiss agricultural and food markets, followed by an overview of the three articles.

\section{About Switzerland's agricultural and food markets}

Despite a gradual market opening over the past 20 years, Switzerland seems to remain an island of high and stable agricultural and food prices in the middle of Europe. This particularity has been part of both public perception (Sax and Weder 2009, Rudolph et al. 2015) and policy debate (OECD 1992, SECO 2008, OECD 2019) for decades.

Indeed, numbers provide evidence for the existence of such a "high price island" as Switzerland is often labeled (Eichenberger 2005). The country has the highest consumer and producer price indices in Europe, and for food and agricultural products, the difference to neighboring countries is even higher than on aggregate level, with a Swiss food price level of $66 \%$ above EU-15 average (Eurostat 2019). Although there is consensus on the high price level, it is not clear whether this Swiss (food) price island really is as isolated and pricing as rigid as perceived.

There have rarely been any empirical analyses on how international prices influence Swiss agricultural and food prices. To date, there is only one published case study on spatial price transmission for wheat, which found no or only very weak links to international markets, depending on the type of wheat (bread vs. feed wheat) and the respective policy setting (Esposti and Listorti 2018). With its particular reference and entry price system, the study's results cannot readily be transferred to other products. Also insights from other countries are only of limited usefulness, given the particular Swiss country characteristics, especially the policy setting and market structure.

Until the 1990s, Swiss agricultural markets were largely under state control, based on public price and volume guarantee schemes. After Switzerland became a member of the World Trade 
Organization in 1995, and following the Uruguay round, markets have gradually opened up (Koch 2002). Yet, in many areas subsidies and border protection remain high, with the explicit aim to "protect" the domestic market, i.e., to stabilize Swiss prices by reducing price volatility coming from international markets, especially on producer level (Loi et al. 2016).

Therefore, the first part of this thesis deals with spatial price transmission between the Swiss and the surrounding EU market. The focus will be on the milk market for several reasons. Firstly, milk is the most important agricultural product in Switzerland in many ways. Milk, cows and cheese are closely linked to the Swiss alpine identity, and the milk market contributes to about $25 \%$ of the national agricultural production value (SBV 2013). Furthermore, there are large trade flows of milk products; in 2017, more than 800 million tons whole milk equivalent (WME) were exported and around 450 million WME were imported (SMP 2019). Whereas hard cheese such as Emmentaler and Gruyère are the major export products, other cheese types such as soft and cream cheese are imported in large volumes. The milk market also provides an interesting case study because Switzerland applies a number of different border protection policies for milk products (Haller 2014, FOAG 2017). In the milk market, the stepwise liberalization process has resulted in a variety of border protection measures for different dairy products present today: tariff rate quotas (TRQs), single tariffs and a full free trade agreement with the EU for cheese (Koch 2002, Haller 2014). Such different trade barriers for joint products produced from raw milk may have an influence on price transmission and market integration with Switzerland's trade partners.

Moreover, the Swiss milk market is characterized by a particular market structure: At the farm level, there are more than 20,000 producers (SMP 2019). In 2017, about $44 \%$ of all Swiss farms engaged in milk production, mainly family-run small-scale farms with on average 25 cows (TSM et al. 2017). The raw milk then goes into two processing lines: About $43 \%$ is processed into cheese, and the remaining $57 \%$ is processed into other, non-cheese dairy products (SMP 2019). In cheese processing, small, artisanal processors dominate the market, with some hundred processors engaged (Haller 2014). These small, artisanal processors mainly produce hard and semi-hard cheese from non-pasteurized raw milk, subject to strict quality criteria. Some industrial-type cheese from pasteurized milk is also produced by large dairy processors. However, the remaining non-cheese dairy processing is highly industrialized and has undergone a concentration process and several mergers, with four large processors remaining (Flury et al. 2014, SMP 2019). Especially for perishable and bulky raw milk, with no storage or transportation possibilities, these processors might possess a spatial oligopsony power and consequently 
price setting power (Sexton 1990). The retail sector, too, is highly concentrated and often described as a duopoly, because two retailers account for more than $70 \%$ of the market share (FDFA 2017).

Given this background, and especially the differences in market structures between cheese and dairy processing, a part of this dissertation focuses on vertical price transmission along Swiss cheese and dairy chains.

\section{Overview of the articles}

The first article, "Protecting the Swiss milk market from foreign price shocks: Public border protection vs. quality differentiation" (chapter II), focuses on spatial price transmission between the EU and Switzerland. In Switzerland, different trade policies apply for different milk products: Dairy products such as milk powder and butter are still subject to tariffs and TRQs, whereas cheese trade with the EU is fully liberalized. At the same time, cheese and other dairy products differ regarding their degree of qualitative differentiation. Butter and milk powder are generally considered homogeneous bulk commodities, produced from pasteurized milk. Swiss cheese products, on the other hand, are more heterogeneous, with a large variety of types, brands and regional restrictions. This is especially the case for the typical Swiss hard and semihard raw milk cheese, such as Emmentaler and Gruyère.

This situation leads us to the following research questions: How strong is the influence of neighboring EU prices on Swiss prices for different milk products, both for the processed products and for the underlying raw milk producer prices? How does this influence differ for products with different levels of (a) protective trade policies and (b) qualitative differentiation?

To assess these questions, we analyze price transmission between Germany and Switzerland for dairy products (whole milk powder, skimmed milk powder, butter) and for cheese (hard and semi-hard cheese). We use monthly average wholesale prices and raw milk producer prices in the different processing channels from January 2000 to May 2017. Applying cointegration analysis and vector error correction models, we compare how fully and at what speed price developments in Germany are transmitted to Switzerland. We choose Germany because it is a major trade partner for milk products and a good representative of the overall EU price development (Benedek et al. 2017, FOAG 2017).

The third chapter presents the second manuscript, "Vertical price transmission in Swiss dairy and cheese value chains." This article complements the first article by investigating the vertical price pass-through within Switzerland in both the dairy and the cheese segment. Because milk 
is the most important agricultural product for farm income, milk producer prices, and how more value can be retained at this stage, have received quite some attention (SBV 2013, Reviron et al. 2017). However, the price linkages between the different stages of the dairy and cheese value chains have not yet been analyzed systematically and quantified. Therefore, we investigate vertical price transmission along Swiss value chains. In particular, we distinguish between the "artisanal" cheese and the "industrial" dairy processing systems, as they differ in terms of structure, industry concentration and value chain governance.

The research questions therefore are: How fully and how quickly are prices passed on along Swiss cheese and dairy value chains? Are there any asymmetries regarding price increases and decreases? Do the different characteristics of the Swiss dairy and cheese processing chains have an influence on price transmission?

The study is based on monthly price data on farm gate, wholesale, export and retail levels from 2004 until 2018. For all price pairs within a processing line, linear Johansen cointegration and threshold cointegration tests are applied (Johansen 1988, Balke and Fomby 1997, Enders and Granger 1998) to test for long-run relationships between prices. Depending on the outcome, different models are chosen to estimate the pairwise price transmission and price adjustment processes. For linearly cointegrated price pairs, vector error correction models (VECM) are estimated. For threshold-integrated price pairs, and to account for asymmetries, threshold autoregressive (TAR) and momentum threshold autoregressive (MTAR) models are specified, following an approach by Enders and Siklos (2001). For non-cointegrated price pairs, vector autoregressive (VAR) models in first differences are estimated to study short-run dependencies between the prices.

The fourth chapter presents the third manuscript, "Market integration and market efficiency under seasonal tariff rate quotas." Whereas the first two articles focus on price data and price transmission processes, here the scope is extended to the analysis of physical market integration. In this article, price information is combined with data on trade costs and trade flows. As noted by Barrett (1996), combining data on prices and trade activities allows better understanding of the interactions of different markets in the agricultural sector. This is especially true for markets with strongly seasonal trade patterns, as for the case of many Swiss fruits and vegetables for which seasonal TRQs apply during the domestic supply season. TRQs are a popular instrument to control market access, particularly for politically sensitive agricultural products (Beckman et al. 2017, WTO 2019). Also in Switzerland, most agro-food imports are regulated by TRQs, covering meat, milk products, potatoes, bread cereals and wine. Non-seasonal TRQs 
have received considerable research attention, and their effects on prices and trade patterns are quite well understood (e.g., Skully 2001). Less is known about the effects of seasonal TRQs on fresh fruits and vegetables, which are applied not only in Switzerland but also in the EU, Iceland, Norway and South Korea (WTO 2019). In Switzerland, these seasonal TRQs cover 60 products, and hence almost all fresh fruits and vegetables that are grown domestically in relevant quantities (Swiss Federal Council 2008, Swisscofel 2018). These TRQs are in effect only during domestic harvest seasons. In the rest of the year, when there is no local produce to be protected from imports, no or only low tariffs apply. Given the wide application of seasonal TRQs and the lack of previous empirical studies, we analyze how this policy instrument affects market integration and market efficiency using the example of Italian tomato imports. The article aims to answer the following research questions:

How are the Swiss and the Italian tomato markets physically integrated under the seasonal TRQ system, i.e., how large are the trade volumes inside and outside the administered periods? How does the seasonal TRQ system affect market efficiency, i.e., are markets in an efficient equilibrium, where excess rents are extinct by competitive pressure, or are there rents created for importers holding quota shares?

To study how seasonal TRQs applied by Switzerland affect Italian-Swiss tomato trade, market integration and rents throughout the year, we use a parity bounds model (PBM) approach, first suggested by Spiller and Huang (1986). We follow an extended version of the PBM by Barrett and $\mathrm{Li}$ (2002) and use detailed weekly customs data on trade flows, tariff costs and prices from 2011 until 2015. With the help of the PBM, we can identify different cases or "regimes" regarding physical market integration and market efficiency. We then estimate the probability of observing each of these regimes at a given point in time, and how this relates to the administered and non-administered TRQ periods.

The three articles in the following chapters II to IV form the core of this thesis. The final chapter $\mathrm{V}$ summarizes the results, draws conclusions and points out the need for further research. 


\section{References}

Balke, N. S., and Fomby, T. B. (1997). Threshold cointegration. International Economic Review, 38(3), 627-645.

Barrett, C. B. (1996). Market analysis methods: Are our enriched toolkits well suited to enlivened markets? American Journal of Agricultural Economics, 78(3), 825-829.

Barrett, C. B., and Li, J. R. (2002). Distinguishing between equilibrium and integration in spatial price analysis. American Journal of Agricultural Economics, 84(2), 292-307.

Beckman, J., Dyck, J. H., and Heerman, K. E. (2017). The Global Landscape of Agricultural Trade, 1995-2014. US Department of Agriculture, Economic Research Service.

Benedek, Z., Bakucs, Z., Fałkowski, J., and Fertő, I. (2017). Intra-European Union trade of dairy products: insights from network analysis. Studies in Agricultural Economics, $119(2), 91-97$.

Eichenberger, R. (2005). Hochpreisinsel Schweiz: Ursachen, Folgen, wirkungsvolle Rezepte. Available at https://www3.unifr.ch/finwiss/de/assets/public/research/academic\% 20publications/Hochpreisinsel_Schweiz Urschen Folgen wirkungsvolle Rezepte.pdf, last accessed 8 August 2019.

Enders, W., and Granger, C. W. J. (1998). Unit-root tests and asymmetric adjustment with an example using the term structure of interest rates. Journal of Business \& Economic Statistics, 16(3), 304-311.

Enders, W., and Siklos, P. L. (2001). Cointegration and threshold adjustment. Journal of Business \& Economic Statistics, 19(2), 166-176.

Esposti, R., and Listorti, G. (2018). Price transmission in the Swiss wheat market: Does sophisticated border protection make the difference? The International Trade Journal, 32(2), 209-238.

Eurostat (2019). Comparative price levels of consumer goods and services. Available at http://ec.europa.eu/eurostat/en/web/products-datasets/-/TEC00120, last updated 24 June 2019, last accessed 8 August 2019. 
FDFA (Swiss Federal Department of Foreign Affairs) (2017). Detailhandel. Information by the Federal Department of Foreign Affairs. Available at https://www.eda.admin.ch/ aboutswitzerland/de/home/wirtschaft/taetigkeitsgebiete/detailhandel.html, last accessed 8 August 2019.

Flury, C., Sorg, L., and Giuliani, G. (2014). Evaluation der Zulagen für verkäste Milch und für Fütterung ohne Silage. Flury \& Giuliani GmbH, Zürich.

FOAG (Federal Office for Agriculture) (2017). Perspektiven im Milchmarkt. Bericht des Bundesrates in Erfüllung des Postulats 15.3380 der Kommission für Wirtschaft und Abgaben des Nationalrats vom 14.4.2015. FOAG, Bern, 5 April 2017.

Haller, T. (2014). Abolition of the Milk Quota System in Switzerland. Berner Fachhochschule, Burgdorf.

Johansen, S. (1988). Statistical analysis of cointegration vectors. Journal of Economic Dynamics and Control, 12(2-3), 231-254.

Koch, A. (2002). Evaluation der Schweizer Agrarmarktpolitik unter besonderer Berücksichtigung von Unsicherheit. Doctoral dissertation, ETH Diss Nr. 14505. ETH Zürich.

Lloyd, T. (2017). Forty years of price transmission research in the food industry: insights, challenges and prospects. Journal of Agricultural Economics, 68(1), 3-21.

Loi, A., Esposti, R., Gentile, M., Aragrande, M., Bruni, M., Berisio, S., and Saguatti, A. (2016). Policy evaluation of tariff rate quotas. Report mandated by the Swiss Federal Office for Agriculture. Areté, Bologna.

OECD (Organisation for Economic Co-operation and Development) (1992). Economic Surveys: Switzerland 1991/1992. OECD Publishing, Paris.

OECD (Organisation for Economic Co-operation and Development) (2019). Agricultural Policy Monitoring and Evaluation 2019. OECD Publishing, Paris.

Reviron, S., Python, P., Gresset, F., Estève, M., and Bänninger, A. (2017). Wertverteilung in der Wertschöpfungskette. Schlussbericht. Nr. 3177. Agridea, Lausanne. Available at https://agridea.abacuscity.ch/de/ 2044, last accessed 7 August 2019. 
Rudolph, T., Nagengast, L., and Nitsch, F. (2015). Einkaufstourismus Schweiz 2015: Eine Studie zu den aktuellen Entwicklungen des Einkaufstourismus. Forschungszentrum für Handelsmanagement, St. Gallen. ISBN 978-3-906057-16-3.

Sax, C., and Weder, R. (2009). How to explain the high prices in Switzerland? Swiss Journal of Economics and Statistics, 145(4), 463-483.

SBV (Schweizerischer Bauernverband) (2013). Der Schweizer Milchmarkt. 056-462 5111. Available at https://www.sbv-usp.ch/fileadmin/sbvuspch/07_Preise/milch/131204_Milch markt_Schweiz_de.pdf, last accessed 7 August 2019.

SECO (Swiss State Secretariat for Economic Affairs) (2008). Preisinsel Schweiz. Berichte in Erfüllung des Postulates David (05.3816). SECO, Bern.

Sexton, R. J. (1990). Imperfect competition in agricultural markets and the role of cooperatives: a spatial analysis. American Journal of Agricultural Economics, 72(3), 709-720.

Skully, D. W. (2001). Economics of tariff-rate quota administration. US Department of Agriculture, Economic Research Service.

SMP (Swiss Milk Producers) (2019). Schweizer Milchwirtschaft in Zahlen 2018/2019. Available at https://api.swissmilk.ch/wp-content/uploads/2019/06/brochure-smp-schweizermilch

wirtschaft-in-zahlen-2018-2019-195000-de.pdf, last accessed 7 August 2019.

Spiller, P. T., and Huang, C. J. (1986). On the extent of the market: wholesale gasoline in the northeastern United States. The Journal of Industrial Economics, 35(2), 131-145.

Swiss Federal Council (2008). Ordinance on Rates of Duty for Goods in Trade with Member States of EFTA and the EU (Free Trade Ordinance 1, SR 632.421.0, 18 June 2008). Available at https://www.admin.ch/opc/de/official-compilation/2008/3519.pdf, last accessed 7 August 2019.

Swisscofel (2018). Guide réglementation d'importation fruits et légumes. Available at http://www.swisscofel.ch/wAssets/docs/news/Leitfaden-2019.pdf, last accessed 7 August 2019. 
TSM (TSM Treuhand GmbH), SMP (Swiss Milk Producers), SCM (Switzerland Cheese Marketing), and Agristat (2017). Milchstatistik der Schweiz 2016. TSM, Bern, September 2017. ISSN 1423- 4548.

von Cramon-Taubadel, S. (2017). The analysis of market integration and price transmission results and implications in an African context. Agrekon, 56(2), 83-96.

WTO (World Trade Organization). Tariff Download Facility (2019). Available at http://tariffdata.wto.org/, last accessed 7 August 2019 


\title{
II Protecting the Swiss milk market from foreign price shocks: Public border protection vs. quality differentiation
}

\author{
Authors: Judith Hillen und Stephan von Cramon-Taubadel ${ }^{1}$
}

Published in Agribusiness (online since 1 March 2019)

\begin{abstract}
Switzerland applies a number of different border protection policies for milk products. While dairy products such as butter and milk powder are still subject to tariffs and tariff rate quotas, cheese trade with the EU is fully liberalized. To understand how such different levels of protection affect spatial price transmission, we analyze price transmission between Germany and Switzerland for several products at the wholesale level, and for raw milk producer prices. We find that not the level of border protection determines the degree and speed of price transmission, but rather the qualitative differentiation of the Swiss products. While prices of tariff-protected dairy products are influenced by German price developments, cheese prices are not. Also at the producer level, milk prices for cheese processing are less strongly linked to foreign prices than milk prices for industrial dairy production. Our results suggest that for small high-income countries such as Switzerland, promoting high-quality products and hence reducing international substitutability alleviates international price pressure more than protection via tariffs. [EconLit Classifications: Q11, Q13, Q18].
\end{abstract}

KEYWORDS: Milk prices, price transmission, Switzerland, trade policy

1 This paper is coauthored by Prof. Dr. Stephan von Cramon-Taubadel. My contributions are the research idea, conception and data analysis, as well as the writing of the article. The coauthor supported me throughout this process with many valuable comments and suggestions, and contributed to the revision of the article. 


\section{Introduction}

Since the 1990s, the Swiss milk market has gradually been opened, resulting in many parallel border protection policies for different dairy products (Haller 2014, FOAG 2017). In particular, there is a distinction between the liberalized "yellow line" (cheese products) and the still protected "white line" (other milk products, such as butter and milk powder). While cheese trade with the EU is fully liberalized, industrial dairy products such as milk powder and butter are subject to tariffs and tariff rate quotas (TRQs).

Yet, is it not well understood how such different types and levels of protection for products jointly produced from a single commodity influence spatial price transmission. This is valid for the respective products and for raw milk producer prices. Given that globally milk has become one of the most volatile commodities (IFCN 2011), it is relevant to understand how foreign price developments influence domestic wholesale and producer prices in such a setting.

There is a large body of literature on spatial price transmission, including some studies on milk markets. These studies mostly focus on dry milk product prices in the aggregate regions EU, USA, and Oceania and find spatial long-run linkages among these three regions (Fousekis and Trachanas 2016, Newton 2016, Zhang et al. 2017). Studies looking at fluid milk prices find some spatial price transmission from global markets to smaller countries, such as Panama (Acosta et al. 2014) and the Netherlands (Carvalho et al. 2015). Testing for raw milk market integration among $20 \mathrm{EU}$ member states, Bakucs et al. (2015) find only $35 \%$ of the price pairs to be cointegrated. Yet, these studies provide limited insights into the situation in Switzerland for which, to date, there is only one case study on spatial price transmission: For Swiss wheat, Esposti and Listorti (2018) find no or only weak links to international markets, depending on the type (bread vs. feed wheat) and the respective policy setting. Since Switzerland applies a particular reference and entry price system for wheat, this study's results cannot be transferred to the milk market.

The aim of our study is to understand to what extent foreign price developments influence Swiss milk and dairy prices. We analyze spatial price transmission between Switzerland and its major trade partner Germany for dairy products that are subject to different trade policies. We assess wholesale prices for tariff-protected industrial dairy products (butter and milk powder) and liberalized cheese products (hard- and semi-hard cheese). In addition, we analyze spatial producer price transmission for raw milk intended for either dairy- or cheese-processing.

We find weak or no spatial price transmission at the wholesale level, but strong linkages on the producer level. Hence, while tariffs and tariff rate quotas appear to "protect" domestic prices 
for the respective products at the wholesale level, they do not hinder price transmission for the input raw milk. In fact, the price of raw milk intended for processing into (protected) white-line products is more dependent on German price developments than raw milk that is used to produce (liberalized) cheese, and qualitatively differentiated raw milk for artisanal cheese production or from organic production is the least dependent of all.

Our results suggest that qualitative differentiation can protect domestic producer prices from foreign price shock at least as well or even better than traditional border measures. Especially for a small high-income country such as Switzerland, positioning domestic products in highquality, differentiated product segments may be a more efficient way to remain competitive and to alleviate price pressure. While tariffs aim to disturb the price relationship between foreign and domestic products, qualitative differentiation reduces the substitutability between the products. In addition, differentiation does not generate the net welfare losses associated with border protection. While our analysis highlights the role that differentiation can play, it only provides a partial explanation of the formation of market prices and ultimately price transmission. Since we work with aggregate price data, we cannot account for all of the differences in the functioning and structure of the supply chains in the analyzed countries.

\section{Characteristics of the Swiss Milk Market}

In 2016 , about $41 \%$ of Swiss raw milk was processed into yellow-line cheese products, and the remaining 59\% were used for white-line products such as butter and milk powder. Both the overall production and the product shares are subject to some seasonal variation, but have remained stable over the past years, with a slight increase in cheese production since the early 2000s (FOAG 2017, TSM et al. 2017).

\subsection{Processing channels}

The processing channels for cheese and other dairy products are quite strictly separated in Switzerland. Raw milk intended for the white line is generally bought by large industrial dairy processors or producer organizations as a homogeneous bulk product (Mann and Gairing 2011, Flury et al. 2014). For such standardized dairy products, price and volume are decisive competition factors (Stræte 2008).

Farmers who supply to the yellow-line cheese dairies often face specific quality requirements, especially silage-free feeding for raw milk cheese production. Cheese is produced by several hundred regional and artisanal dairies of different sizes (Haller 2014). Some industrial cheese types are also produced by the large dairy processors. 


\subsection{Policy framework}

These differences between the yellow and the white line are also reflected in border policies. White-line dairy products are protected by means of tariffs and TRQs, while the cheese market is liberalized. This situation developed as a result of gradual liberalization steps since the 1990s. Before then, Swiss milk producers and processors were completely insulated from price volatility and world market developments, as the market was based on public price and volume guarantee schemes. After Switzerland became a WTO member in 1995, and following the Uruguay round, its markets for different milk products were subject to different degrees of liberalization, leading to today's situation (Koch 2002).

White-line products are still protected by single tariffs or TRQs, fixed per weight $(\mathrm{CHF} / 100 \mathrm{~kg})$, not per value of the imported good. To make tariffs comparable, we calculate ad valorem equivalents (AVE) in percentage terms. However, these AVEs can vary due to changes in foreign price developments and exchange rates, even if the nominal tariff stays the same.

Table 1 summarizes the border policies in effect for the products that will be included in our empirical analysis. For skimmed milk powder (SMP), there is a regular single tariff (72\% AVE). For butter and whole milk powder (WMP), TRQs are in place, with low tariffs for fixed yearly quotas (5\% AVE for $100 t$ for butter, 13\% AVE for 300t for WMP). These quotas are generally fully exploited. Out-of-quota tariffs for butter and WMP are 341\% and 171\%, respectively, which is prohibitively high and makes both quotas binding. For more details on the Swiss TRQ system, see Loi et al. (2016).

Table 1: Swiss border protection policy type and level for selected dairy products

\begin{tabular}{llrr}
\hline Product & Policy type & In-Quota AVE & $\begin{array}{r}\text { Out-of-quota / } \\
\text { Single tariff AVE }\end{array}$ \\
\hline Butter & TRQ & $5 \%(100$ t p.a. $)$ & $341 \%$ \\
WMP & TRQ & $13 \%(300$ t p.a. $)$ & $171 \%$ \\
SMP & Single tariff & n/a & $72 \%$ \\
Cheese & Free trade (EU) & n/a & $0 \%$ \\
\hline
\end{tabular}

Source: Own calculations, based on FOAG/customs data

$\mathrm{AVE}=$ ad valorem equivalent; $\mathrm{WMP}=$ Whole milk powder; $\mathrm{SMP}=$ Skimmed milk powder; TRQ = Tariff Rate Quota; n/a = not applicable

As a result of prohibitive tariff protection, Switzerland, with a few small exceptions, does not import unprocessed raw milk. The exceptions are Liechtenstein and a defined border zone close to Geneva, which are exempted from tariffs (Agricultural import regulation, Art. 35.1). Also, dairy products and cheese need to contain $100 \%$ Swiss milk to be labeled as "Swiss" (Trade 
Mark Protection Act, Art. 48b). Hence, there is no direct trade and arbitrage opportunity for raw milk.

For cheese, which is Switzerland's most important dairy export product, a free trade agreement with the EU is in place (Haller 2014). This liberalization took place gradually, starting in 2002 and resulting in full free trade after July 2007. Since this market opening, both imports and exports of cheese have increased (FOAG 2017). To offset the expected liberalization effects on milk producer revenues, a government payment for milk processed into cheese was introduced in 1999. Starting with $0.20 \mathrm{CHF}$ per kilogram of raw milk, the payment was gradually reduced to 0.15 CHF between 2004 and 2007. This support is paid to cheese processors once the raw milk has been processed into cheese. The cheese dairies are required to forward this subsidy to the milk producers. Yet, it is estimated that only about two-thirds of it are actually passed on to the farmers (see Finger et al. 2017 for more details).

Further policy events were the abolishment of the milk production quota in Switzerland (in May 2009) and in the EU (in April 2015). The Swiss public quota system ended gradually with long transition periods, and was followed by a private-law quota system that continues to control production quantities (Haller 2014, FOAG 2017). This explains why abolishment of the quota did not lead to increased production and falling prices (Mann and Gairing 2011), as was the case in the EU.

Because of these gradual, recent and partly overlapping policy changes, it is not possible to conduct rigorous evaluations of individual changes. Instead, we include these changes as explanatory or dummy variables in robustness checks of the later analysis to get insights into the direction and significance of their effects on prices.

\subsection{Trade situation}

Switzerland is a net exporter of aggregate milk products with a self-sufficiency of $117 \%$. Cheese is the most important export product (TSM et al. 2017). Table 2 shows that more than half of Swiss hard cheese production is exported, including well-known specialties such as Emmentaler and Gruyère. Simultaneously, there are notable imports especially of more industrial types of cheese such as fresh cheese and mozzarella (33.9\% and $20.8 \%$ of the domestic production volume respectively). 
Table 2: Relative import and export shares, as percentage of domestic production volume (average for years 2000 - 2016)

\begin{tabular}{llrr}
\hline Product & Policy type & Import (\%) & Export (\%) \\
\hline Fluid milk & TRQ & $5.0^{*}$ & 0.8 \\
Butter & TRQ & 4.0 & 5.4 \\
WMP & TRQ & 3.6 & 11.7 \\
SMP & Single tariff & 2.4 & 45.0 \\
Cheese (all) & free trade & 24.2 & 32.4 \\
Fresh cheese/curd & free trade & 33.9 & 6.9 \\
Mozzarella & free trade & 20.8 & 10.8 \\
Hard cheese & free trade & 3.1 & 51.6 \\
\hline
\end{tabular}

* imports only from free trade zone (Geneva) and Liechtenstein

Source: Own calculations, based on FOAG data

Because of trade-restricting border policies, imports account for less than 5\% of domestic production volume for all non-cheese dairy products. The only notable white-line export good is SMP, for which $45 \%$ of domestic production is exported.

The EU is by far Switzerland's largest trade partner, receiving about $80 \%$ of its cheese exports (TSM et al. 2017). Hence, the following analysis is exclusively concerned with trade policies between Switzerland and EU member states, not vis-à-vis the rest of the world.

\subsection{Product characteristics and differentiation}

White-line dairy products such as butter and milk powder are generally considered homogeneous bulk commodities, produced from pasteurized milk. Yellow-line Swiss cheese products are more heterogeneous, with a large variety of types, brands and qualities, especially for the typical Swiss hard- and semi-hard raw milk cheese. At the retail level, such product differentiation, e.g., through different brands, has been analyzed in previous studies that focus on the vertical transmission of milk prices (e.g., Loy et al. 2015, Li et al. 2018). At the producer level however, agricultural products such as milk are often classified as undifferentiated, i.e., milk is milk at the farm gate. Even though this perception is changing (Grunert 2005), previous price transmission studies only analyze aggregate raw milk prices and neglect the possible effect of quality differentiation.

In our study, we separate price data for raw milk by processing channel: Non-organic milk for processing into white-line products, cheese, and artisanal cheese, as well as organic milk. Hence, we can derive information about quality characteristics both at the producer and the wholesale level. 
In addition to quality differences between product types, in Switzerland there is evidence of a general preference for domestic products. More than $80 \%$ of consumers pay attention to "Swissness" when purchasing cheese and dairy products (FOAG 2015). Some consumer groups display an additional willingness to pay premium prices for domestic products, as they associate Swiss products with higher product quality, food safety, and ecological standards (Bolliger and Réviron 2008, Bolliger 2011). Previous studies on industrial goods find that such a consumer "home bias" is mainly caused by locational factors, such as geographical distance, tariffs and distribution barriers (e.g., Evans 2001, Hillberry and Hummels 2003 and 2008). In our case however, it is at least partly due to an inherent preference for domestic agricultural products.

Food quality is a broad and multi-dimensional concept that involves both producers and consumers perceptions, preferences and requirements (Morris and Young 2000; Callon et al. 2002). For our purposes we distinguish between horizontal and vertical quality differentiation. While horizontal differentiation just describes a variety of product, for which preferences are purely individual (e.g., different cheese brands), vertical quality differentiation implies that a general ranking between superior and inferior products can be made based on some objective criteria. In our case, this could be the following: At the producer level we consider two attributes to contribute to "higher" quality: (a) silage-free feeding, as required for raw milk cheese production, and (b) organic production, as opposed to conventional dairy milk production. At the processing stage, we define cheese processing, and especially artisanal cheese processing as "higher" quality because of the more time-consuming and more costly procedures, compared with industrial dairy processing. If products are perceived as qualitatively differentiated, whether for the above-named attributes, or because of other, less tangible cognitive or affective reasons, this differentiation can alleviate price competition (Rosen 1974, Shaked and Sutton 1982; Chen et al. 2017).

Competing via quality differentiation rather than price may be especially feasible in a highincome and high-cost country such as Switzerland: First, Switzerland is a small market with a large demand for high-quality products and the necessary purchasing power to pay for them (Bolliger 2011, FOAG 2017). Second, it has the highest average costs of milk exporting nations worldwide, which are only partly compensated through subsidies and direct payments (Hemme et al. 2014). Despite these high costs, farmers and processors continue to produce and even export certain milk products. They do so most successfully with cheese specialties, where the domestic market is subject to the least protection. This positioning of Swiss products into a 
differentiated, high-quality segment could provide Swiss producers and processors with an indirect form of protection that helps them avoid direct competition on the basis of costs, as it is the case for bulk products.

\subsection{Hypotheses}

Following the idea of the "Law of One Price" (LOP), a standard assumption is that arbitrage and physical trade are the drivers of market integration. Whenever prices differ between two separate markets, spatial arbitrage will remove this difference, at least in the long-run, allowing for adjustment times and accounting for trade cost (Fackler and Goodwin 2001). As Switzerland is a small country and in principle an open economy, we expect it to be influenced by external, especially neighboring European price developments if no trade restrictions are in place. This is the case for cheese, where trade with the EU is liberalized and markets are connected through large bi-directional trade flows.

\section{H1: In liberalized, tariff-free markets, EU and Swiss prices are highly integrated.}

Conversely, public border protection measures applied to white-line dairy products can be expected to hinder international trade and hence impede arbitrage when prices differ. The main border measures for dairy products are TRQs with low, binding quotas and prohibitively high out-of-quota tariffs (see table 1). Such clearly trade-inhibiting policies are assumed to constrain the pass-through of prices internationally (Conforti 2004; Bonnet et al. 2015). Fixed tariffs, as in place for SMP, however, should only affect the price spread between two markets, just like fixed transaction costs, but not the speed of price transmission (Conforti 2004). Yet, for SMP with an ad-valorem equivalent of $72 \%$ and very low observed import volumes $(2.4 \%$ of Swiss production volume, see tables 1 and 2), also this measure is practically trade-inhibiting. Consequently, for all dairy products, trade volumes and physical market integration are low, which will limit the exposure of Swiss products to price competition from imported products.

\section{H2: Products subject to trade-restricting policies have lower price transmission elasticities.}

Besides public policy measures, spatial arbitrage can also be inhibited by qualitative differentiation of products, leading to lower international substitutability (Shaked and Sutton 1982). The LOP only applies to homogeneous products, which are considered perfect substitutes and hence share the same demand curve. If domestic products are perceived as different or superior to (imported) potential alternatives, this will reduce their international substitution elasticities and consequently the dependence on foreign price developments. If this differentiation is very strong, two products may be such weak substitutes that they are no longer considered to be part 
of the same market. Consequently, there is no longer a direct price relationship through arbitrage and the LOP, but only an indirect link via cross-price elasticities. This may for example apply to Swiss specialty cheese or organic products.

\section{H3: The higher the qualitative differentiation, the lower the price transmission elasticity.}

To sum up, there are two product groups in the Swiss milk market: First, there are protected, but homogeneous bulk products such as butter and milk powder. Second, there are highly differentiated cheese products, for which trade with the EU is fully liberalized. Following the trade barriers and physical market integration hypotheses (H1) and (H2), cheese products and raw milk intended for cheese processing should be more integrated with foreign prices than prices in the dairy line. Following the differentiation hypothesis (H3), the opposite would be the case. In the following we test whether public policy or product characteristics play the dominant role for spatial price transmission.

\section{Data and Methods}

Methods to study spatial price transmission and market integration have evolved over the past thirty years (for reviews, see e.g., Fackler and Goodwin 2001, Hassouneh et al. 2012, von Cramon-Taubadel 2017). We follow a widely used approach; testing for unit roots and cointegration and subsequently estimating pairwise vector error correction models (VECM) or vector autoregressive (VAR) models in first differences. We choose this procedure for the following reason: We are specifically interested in the presence and strength of a long-run relationship (cointegrating vector) between the prices, and short-term deviations from and adjustments to it. Estimating and comparing these model parameters is crucial for our purpose of understanding price transmission in the long- and short-run for joint products under different policy regimes. 
Table 3: Descriptive summary statistics of monthly milk and dairy price data

\begin{tabular}{|c|c|c|c|c|c|c|c|}
\hline & \multicolumn{4}{|c|}{ General information } & \multicolumn{3}{|c|}{ Summary statistics } \\
\hline & Timeframe & nobs & Source & Unit & mean & sd & $\mathrm{cv}$ \\
\hline \multicolumn{8}{|l|}{ Raw milk prices } \\
\hline CH - Dairy milk & $01 / 2000-05 / 2017$ & 209 & FOAG & $\mathrm{CHF} / 100 \mathrm{~kg}$ & 67.4 & 8.5 & 0.13 \\
\hline CH - Cheese milk (all) & $01 / 2000-05 / 2017$ & 209 & FOAG & $\mathrm{CHF} / 100 \mathrm{~kg}$ & 72.1 & 5.0 & 0.07 \\
\hline $\mathrm{CH}$ - Cheese milk (artisan) & $01 / 2000-05 / 2017$ & 209 & FOAG & $\mathrm{CHF} / 100 \mathrm{~kg}$ & 74.5 & 3.5 & 0.05 \\
\hline $\mathrm{CH}$ - Organic milk & $01 / 2000-05 / 2017$ & 209 & FOAG & $\mathrm{CHF} / 100 \mathrm{~kg}$ & 82.6 & 7.2 & 0.09 \\
\hline DE - Conventional milk & $01 / 2000-05 / 2017$ & 209 & Eurostat & $\mathrm{CHF} / 100 \mathrm{~kg}$ & 43.6 & 7.4 & 0.17 \\
\hline DE - Organic milk & $01 / 2007-05 / 2017$ & 125 & AMI & $\mathrm{CHF} / 100 \mathrm{~kg}$ & 57.8 & 8.5 & 0.15 \\
\hline \multicolumn{8}{|l|}{ Wholesale prices } \\
\hline $\mathrm{CH}-\mathrm{SMP}$ & $01 / 2004-05 / 2017$ & 161 & FOAG & $\mathrm{CHF} / 100 \mathrm{~kg}$ & 446.9 & 42.1 & 0.09 \\
\hline CH - WMP & $01 / 2004-05 / 2017$ & 161 & FOAG & $\mathrm{CHF} / 100 \mathrm{~kg}$ & 635.7 & 33.1 & 0.05 \\
\hline $\mathrm{CH}$ - Butter & $01 / 2004-05 / 2017$ & 161 & FOAG & $\mathrm{CHF} / 100 \mathrm{~kg}$ & 1008.0 & 71.8 & 0.07 \\
\hline $\mathrm{CH}$ - Hard cheese & $01 / 2000-05 / 2017$ & 209 & FCA & $\mathrm{CHF} / 100 \mathrm{~kg}$ & 996.2 & 100.5 & 0.10 \\
\hline CH - Semi-hard cheese & $01 / 2000-05 / 2017$ & 209 & FCA & $\mathrm{CHF} / 100 \mathrm{~kg}$ & 1279.0 & 110.9 & 0.09 \\
\hline DE - SMP & $01 / 2000-05 / 2017$ & 209 & Eurostat & $\mathrm{CHF} / 100 \mathrm{~kg}$ & 320.9 & 84.3 & 0.26 \\
\hline DE - WMP & $01 / 2000-05 / 2017$ & 209 & Eurostat & $\mathrm{CHF} / 100 \mathrm{~kg}$ & 380.3 & 80.7 & 0.21 \\
\hline DE - Butter & $01 / 2000-05 / 2017$ & 209 & Eurostat & $\mathrm{CHF} / 100 \mathrm{~kg}$ & 442.6 & 78.0 & 0.18 \\
\hline DE - Emmental type & $01 / 2000-05 / 2017$ & 209 & Eurostat & $\mathrm{CHF} / 100 \mathrm{~kg}$ & 595.0 & 119.2 & 0.20 \\
\hline DE - Gouda type & $01 / 2000-05 / 2017$ & 209 & Eurostat & $\mathrm{CHF} / 100 \mathrm{~kg}$ & 417.2 & 84.5 & 0.20 \\
\hline FX - CHF/EUR exchange rate & $01 / 2000-05 / 2017$ & 209 & SNB & CHF/EUR & 1.40 & 0.19 & 0.14 \\
\hline
\end{tabular}

$\mathrm{CH}=$ Switzerland; DE = Germany; AMI = Agrarmarkt Informations-Gesellschaft, FCA = Swiss Federal Customs Administration, $\mathrm{FOAG}=$ Swiss Federal Office for Agriculture, $\mathrm{SNB}=$ Swiss National Bank, $\mathrm{sd}=$ standard deviation, $\mathrm{cv}=$ coefficient of variation

\subsection{Data}

We use monthly Swiss average producer and wholesale prices from January 2000 to May 2017 (see table 3). As external price reference, we choose Germany, which is a direct neighbor and major trading partner for dairy products (FOAG 2017). Moreover, Germany has the most central position in the EU trade network for milk, and is hence an adequate representative of overall EU price developments (Benedek et al. 2017). ${ }^{2}$

Prices are kept in original currencies (CHF and EUR) and the exchange rate is included as another endogenous variable in the analysis. Our study does not include transaction or transport costs and hence assumes them to be constant, which is frequently criticized (e.g., Abdulai 2000, Goodwin and Piggot 2001, Balcombe et al. 2007). Yet, in this setting we have reason to assume low and stable trade costs: First, the distance between Germany and Switzerland is short, and

2 For producer prices, the same analysis was conducted with French, Italian and EU15 reference prices. Results are available upon request. 
the infrastructure is good. Second, the most-traded products cheese and milk powder are characterized by high value-to-volume ratios and low perishability, both of which are associated with low trade costs (Hummels 1999, Limao and Venables 2001).

As the milk price in Switzerland is made up of several components including subsidies, premiums and deductions, we chose the prices in such a way as to make them as comparable as possible. Prices include VAT and the cheese processing payment. Any other price premiums (e.g., for silage-free production) and deductions are not included. The following types of raw milk are analyzed:

_ "Dairy milk" for production of any non-cheese products

- “Cheese milk (all)" for cheese production by industrial or artisanal cheese dairies

- "Cheese milk (artisanal)" for cheese production by cheese dairies classified as "artisanal" by the Swiss Federal Department of Economic Affairs (1999).

- “Organic milk" for any processing channel, standards defined by Bio Suisse (2015).

On wholesale level, for industrial dairy products, complete and consistent price data are only available from January 2004. The following monthly prices are analyzed:

- Butter (industrial butter for cooking or further processing)

- Whole milk powder (WMP), with 26\% fat in dry mass, for industrial processing

- Skimmed milk powder (SMP), with $<1.5 \%$ fat in dry mass, for industrial processing

For cheese, average Swiss domestic prices are only available at the retail level. As retail prices show almost no variation and in order to stay at the level stage of the value chain, we use export unit values of wholesale trade. However, export unit values do not necessarily represent average domestic prices, but are strongly influenced by the quality of the exported products (Hallak 2006). Therefore, we narrow down the product range to two categories:

- Hard cheese, $>45 \%$ fat in dry mass, made from silage-free raw milk

- Semi-hard cheese, varying fat content, from raw or pasteurized milk

In both categories, few selected Swiss specialty brands with either protected origin or a registered trademark are included to ensure comparability of the prices over time. The German reference prices are Emmental type hard cheese and Gouda type semi-hard cheese. Hard and semihard cheese are chosen due to their large production and trading volumes.

\subsection{Descriptive statistics}

For all analyzed milk products, Swiss prices are always higher than German prices, expect for milk powder during a short period in 2008 (figure 1). Besides this level difference, the volatility 
differs as well: For butter and milk powder, Swiss prices display less variation than German prices. Swiss cheese prices have a larger short-term variation, which may be due to the different data source (export unit values instead of average wholesale prices).

Swiss and German raw milk prices display seasonality (figure 2). The prices of Swiss raw milk for cheese and dairy processing follow very similar paths until 2008; then the gap widens and raw milk for cheese production sells for higher prices than industrial dairy milk.

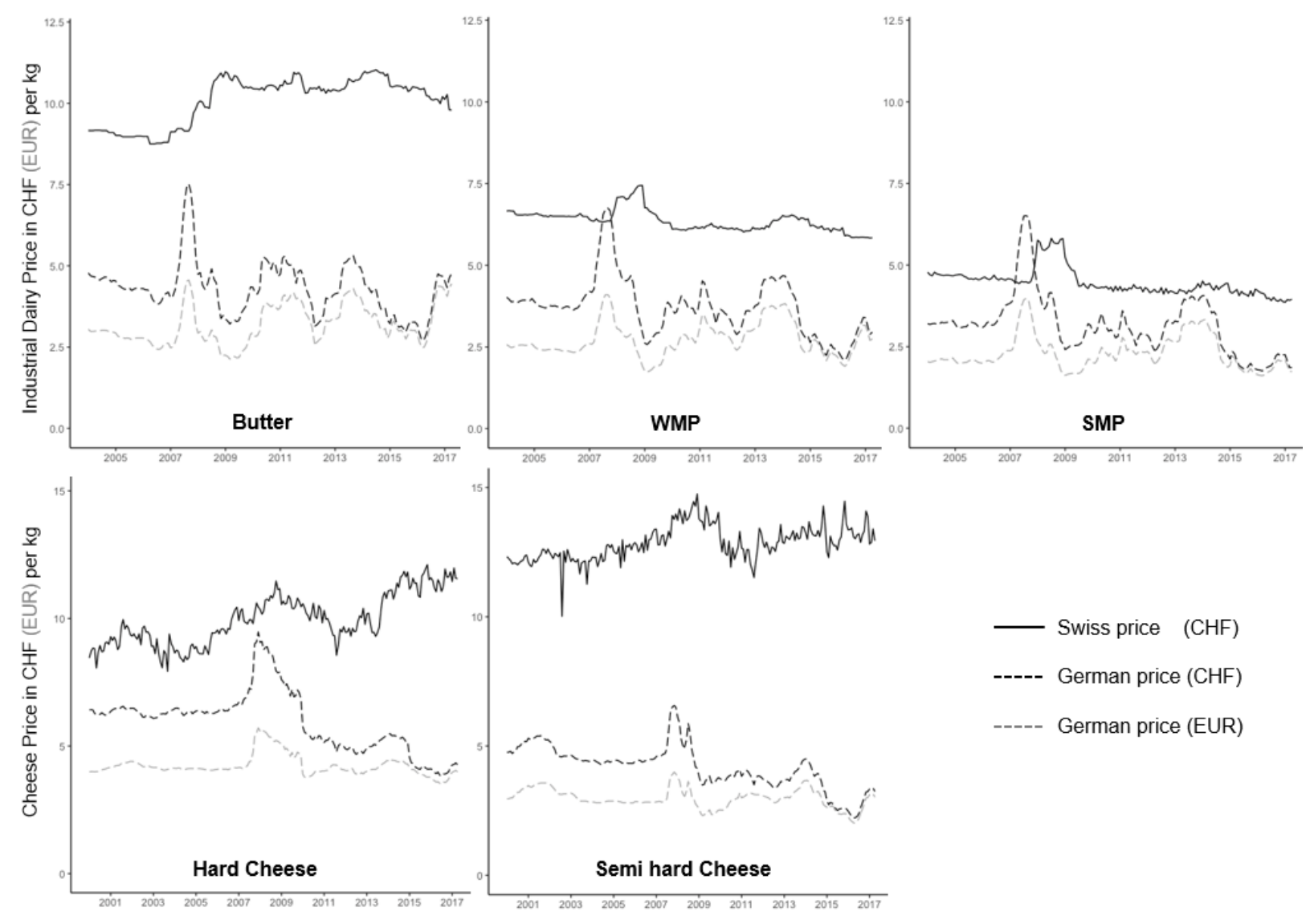

Figure 1: Monthly Swiss and German wholesale prices for dairy products and cheese (per kg)

Source: Own representation based on FOAG, DG Agri, FCA 


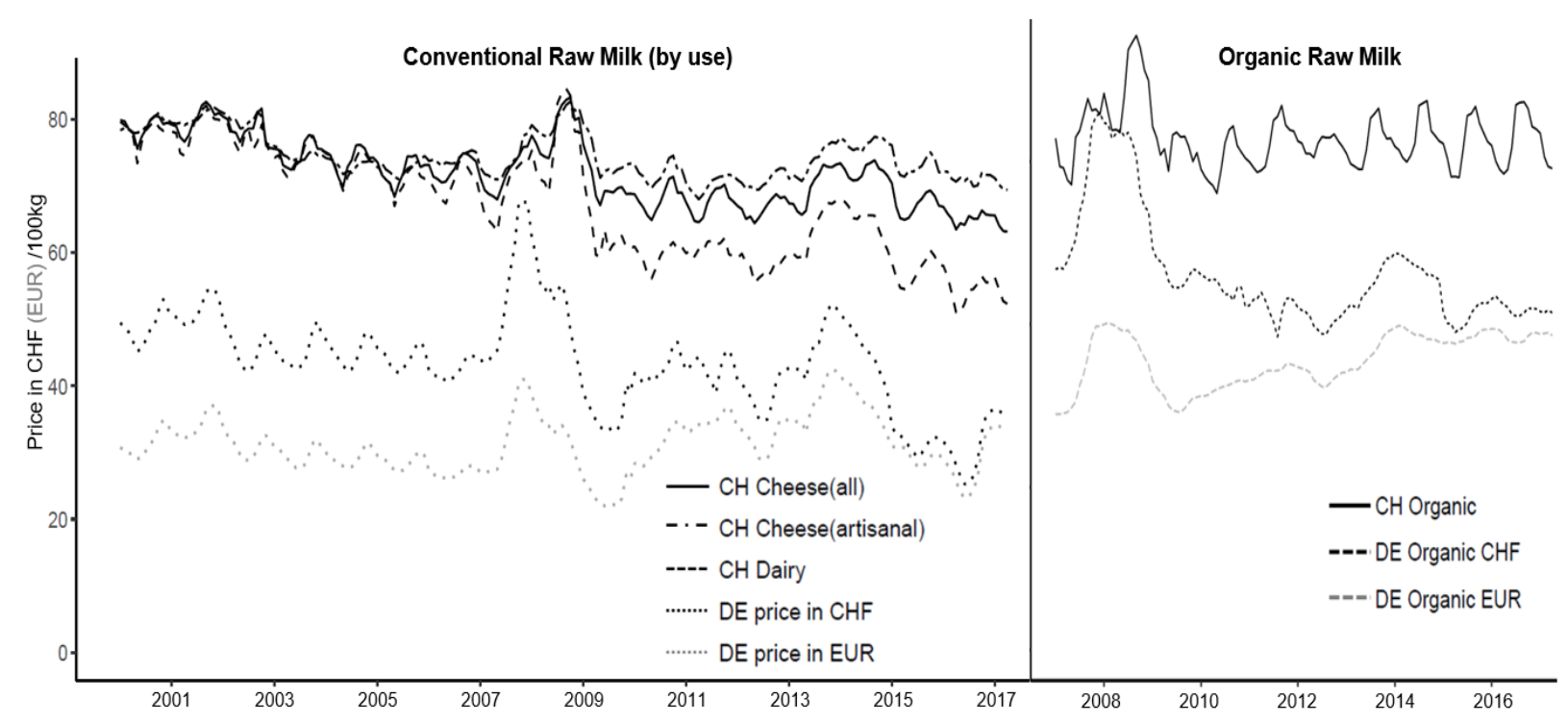

Figure 2: Monthly Swiss and German raw milk producer prices (CHF/100kg) Source: Own representation based on FOAG, DG Agri, AMI

\subsection{Individual testing for unit roots and structural breaks}

First, we test all price series individually on their statistical properties. Both the null hypothesis of a unit root and the null hypothesis of stationarity are tested to better detect "near unit root processes" (Esposti and Listorti 2013). To account for the time-varying variance, we conduct the Phillips-Perron (1988) unit root test, which is robust to heteroskedasticity in the error term, as it uses the Newey-West (1987) heteroskedasticity- and autocorrelation-consistent covariance matrix estimator and corrects the error term using a Bartlett window. To detect structural breaks, we employ the Zivot and Andrews (1992) test of the null hypothesis of a unit root process with drift against the alternative of a trend stationary process that allows for a one time break in both the level and the trend. The break date is selected where the t-statistic from the $\mathrm{ADF}$ test of unit root is at a minimum (most negative), i.e., where the evidence is least favorable for the unit root null hypothesis.

\subsection{Cointegration tests}

If prices are found to be non-stationary, they are tested pairwise for cointegration, i.e., whether the two integrated processes share a common stochastic trend, using the Johansen (1988) cointegration test. Seasonality is considered using monthly dummies and the lag-length is selected according to the Bayesian information criterion (BIC). As a third endogenous variable, we include the monthly average CHF/EUR exchange rate. We do not directly convert all series into one currency because exchange rate fluctuations may or may not be fully transmitted in the 
given setting. Liefert and Persaud (2009) point out that tariffs prevent exchange rate transmission if they are trade-prohibiting, and TRQs do so if the quota is operative. Both is the case for the Swiss white-line products.

\subsection{Model specification}

The choice of the appropriate econometric specification to model the price dependencies between the two countries depends on the previously tested characteristics of the time series; resulting in three cases (table 4).

\section{Table 4: Econometric model choice based on results from unit root and stationarity tests}

\begin{tabular}{lll}
\hline Time Series & Model & Dynamic analyzed \\
\hline $\mathrm{I}(0)$ & VAR-Model in Levels & Long-term \\
$\mathrm{I}(1), \mathrm{r}>0$ & Vector Error Correction Model & Long-term + short-term \\
$\mathrm{I}(1), \mathrm{r}=0$ & VAR-Model in First Differences & Short-term \\
\hline
\end{tabular}

$\mathrm{I}(0) / \mathrm{I}(1)=$ integrated of order $0 / 1, r=\operatorname{rank}(\mathrm{r}=1$ implies cointegration $)$;

Source: own representation, based on Hendry and Juselius 2001

If the German and Swiss price of a given product are non-stationary and cointegrated, Vector Error Correction Models (VECM) are applied. $p_{t}^{C H}$ and $p_{t}^{D E}$ represent the respective prices for Switzerland and Germany in original currencies, $f x_{t}$ the average CHF/EUR exchange rate in month $t$, all in logarithmic transformation:

$$
\begin{aligned}
{\left[\begin{array}{l}
\Delta p_{t}^{C H} \\
\Delta p_{t}^{D E} \\
\Delta f x_{t}
\end{array}\right]=} & {\left[\begin{array}{l}
\alpha_{C H} \\
\alpha_{D E} \\
\alpha_{f x}
\end{array}\right]\left[p_{t-k}^{C H}-\beta_{0}-\beta_{1} p_{t-k}^{D E}-\beta_{2} f x_{t-k}\right]+\sum_{i=1}^{k}\left[\begin{array}{ccc}
\delta_{C H j} & \rho_{C H j} & \varphi_{C H j} \\
\delta_{D E j} & \rho_{D E j} & \varphi_{D E j} \\
\delta_{f x j} & \rho_{f x j} & \varphi_{f x j}
\end{array}\right]\left[\begin{array}{c}
\Delta p_{t-i}^{C H} \\
\Delta p_{t-i}^{D E} \\
\Delta f x_{t-i}
\end{array}\right]+} \\
& {\left[\begin{array}{c}
\omega_{C H} \\
\omega_{D E} \\
\omega_{f x}
\end{array}\right]\left[M_{t}\right]+\left[\begin{array}{c}
\gamma_{C H} \\
\gamma_{C H} \\
\gamma_{f x}
\end{array}\right]\left[X_{t}\right]+\left[\begin{array}{c}
\varepsilon_{C H t} \\
\varepsilon_{D E t} \\
\varepsilon_{f x t}
\end{array}\right] }
\end{aligned}
$$

Equation 1 is in first differences, capturing short-term movements, but also includes the longrun equilibrium (cointegrating vector) between both prices, which can be re-arranged into:

(2) $p_{t}^{C H}=\beta_{0}+\beta_{1} p_{t}^{D E}+\beta_{2} f x_{t}$

The coefficient $\beta_{1}$ represents the long-run price transmission elasticity, i.e., how much of the variation in $p_{t}^{D E}$ is passed on to $p_{t}^{C H}$. Analogously, $\beta_{2}$ captures the exchange rate pass-through, and $\beta_{0}$ is a constant. This long-run equilibrium must not hold precisely at all times, but prices 
can meander around it. How strongly and quickly $p_{t}^{C H}, p_{t}^{D E}$ or both return to the common equilibrium, is determined by the error correction terms (ECT) $\alpha_{C H}$ and $\alpha_{D E}$, which ensure the stability of the equilibrium and describe the speed of adjustment. In theory the exchange rate might also adjust to restore the long-run equilibrium (i.e., $\alpha_{f x}$ may differ significantly from zero), but it is unlikely that the $\mathrm{CHF} / \mathrm{EUR}$ exchange rate will respond to developments on milk markets.

The $\delta, \rho$ and $\varphi$ coefficients express the influence of both prices' and the exchange rate's past values on themselves and the respective other variables. Lag length $k$ is selected according to the BIC. The coefficients $\omega$ capture seasonality for the monthly seasonal dummies $\left(M_{1-11}\right) . X_{t}$ is a vector of exogenous variables that might affect the Swiss and the German prices. We include the following dummy variables to account for policy changes, specified as 0 before, and 1 after the change:

- Cheese free trade agreement with EU (07/2007)

- Quota-abolishment in EU (04/2015)

We do not include the end of the Swiss milk production quota (officially 05/2009) because it was gradually replaced by a private-law quota system (Haller 2014). Further, we do not specifically model the TRQs, as the out-of-quota tariffs are prohibitively high, and hence function as a pure quota, with very small yearly import volumes throughout the whole time period (compare tables 1 and 2).

If German and Swiss prices are unit root processes, but not cointegrated in the long-run, a VARmodel in first differences is used to assess short-term dependencies:

(3) $\left[\begin{array}{l}\Delta p_{t}^{C H} \\ \Delta p_{t}^{D E} \\ \Delta f x_{t}\end{array}\right]=\sum_{i=1}^{k}\left[\begin{array}{lll}\delta_{C H j} & \rho_{C H j} & \varphi_{C H j} \\ \delta_{D E j} & \rho_{D E j} & \varphi_{D E j} \\ \delta_{f x j} & \rho_{f x j} & \varphi_{f x j}\end{array}\right]\left[\begin{array}{c}\Delta p_{t-i}^{C H} \\ \Delta p_{t-i}^{D E} \\ \Delta f x_{t-i}\end{array}\right]+\left[\begin{array}{c}\omega_{C H} \\ \omega_{D E} \\ \omega_{f x}\end{array}\right]\left[M_{t}\right]+\left[\begin{array}{l}\gamma_{C H} \\ \gamma_{C H} \\ \gamma_{f x}\end{array}\right]\left[X_{t}\right]+\left[\begin{array}{l}\varepsilon_{1 t} \\ \varepsilon_{2 t} \\ \varepsilon_{3 t}\end{array}\right]$

In this VAR in standard form, all three variables are treated as potentially endogenous and estimated simultaneously. The notation and included variables are the same as in the VECM (equation 1) above and lag length $k$ is again selected based on the BIC. The error terms are assumed to be independent and identically distributed but can be contemporaneously correlated with one another. The crucial difference between the VAR in differences in equation (3) and the VECM in equation (1) is that the former only models short-term adjustments and does not include a long-run cointegrating vector between the included variables. 


\section{Results}

\section{Table 5: Results from unit root and stationarity tests}

\begin{tabular}{|c|c|c|c|}
\hline \multirow[t]{2}{*}{ Tested variable } & PP test & ZA test & KPSS test \\
\hline & $\mathrm{H}_{0}: \mathrm{I}(1)$ & $\mathrm{H}_{0}: \mathrm{I}(1)^{\circ}$ & $\mathrm{H}_{0}: \mathrm{I}(0)$ \\
\hline \multicolumn{4}{|l|}{ Raw milk prices } \\
\hline $\mathrm{CH}$ - Dairy milk & -3.1 & -4.5 & $1.3 * * *$ \\
\hline $\mathrm{CH}$ - Cheese milk (all) & -3.2 & -3.3 & $3.4^{* * * *}$ \\
\hline $\mathrm{CH}$ - Cheese milk (artisanal) & -2.7 & -4.5 & $2.3 * * *$ \\
\hline $\mathrm{CH}$ - Organic milk & -3.4 & -3.5 & $2.32 * * *$ \\
\hline DE - Conventional milk & -2.9 & -4.51 & $1.25 * * *$ \\
\hline DE - Organic milk & -2.7 & -4.89 & $0.52 * *$ \\
\hline \multicolumn{4}{|l|}{ Wholesale prices } \\
\hline $\mathrm{CH}-\mathrm{SMP}$ & -2.8 & -4.61 & $1.6 * * *$ \\
\hline $\mathrm{CH}-\mathrm{WMP}$ & -2.6 & -4.31 & $1.44 * * *$ \\
\hline $\mathrm{CH}-$ Butter & -0.9 & -3.87 & $2.06 * * *$ \\
\hline $\mathrm{CH}$ - Hard cheese & $-4.0 * *$ & -4.61 & $0.18^{* * *}$ \\
\hline $\mathrm{CH}$ - Semi-hard cheese & $-6.5 * *$ & -3.39 & $0.75^{* * *}$ \\
\hline DE - SMP & -2.3 & -3.23 & $0.88 * * *$ \\
\hline DE -WMP & -2.7 & -4.61 & $1.74^{* * *}$ \\
\hline DE - Butter & -2.7 & -3.23 & $0.88^{* * *}$ \\
\hline DE - Emmental type (hard cheese) & -2.5 & -3.01 & $0.97 * * *$ \\
\hline DE - Gouda type (semi-hard cheese) & -3.0 & -4.26 & $2.26 * * *$ \\
\hline
\end{tabular}

${ }^{\circ} \mathrm{H} 0$ : I(1) with drift against HA: I(0) with max.1 breakpoint in intercept and/or trend

Lags selected according to AIC (including seasonality). All prices in original currencies (DE in EUR, CH in CHF).

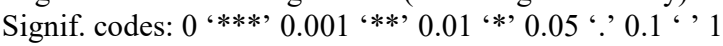

\subsection{Unit root and cointegration tests}

Table 5 shows that all included price series at the producer and wholesale levels are non-stationary unit root processes. The Phillips-Perron tests fail to reject the null hypothesis of a unit root for all prices, except the Swiss cheese prices. This is because of large short-term variations in these export prices; if they are slightly smoothed however, the null is no longer rejected. The Zivot and Andrews test confirms this result by ruling out the alternative of a stationary series with a breakpoint on a 5\% significance level. Further, the KPSS test rejects the null of stationarity for all prices.

Cointegration between Swiss and German prices is found for all conventional raw milk producer prices, but at the wholesale level only for milk powder (whole and skimmed). Applying the Johansen trace test, no cointegration is found for organic raw milk prices, butter, hard cheese 
and semi-hard cheese prices (table 6). Hence, we continue with VECM specifications for products with cointegrated prices (table 7). For the remaining products with no long-run cointegrating relationship, we continue to analyze short-term dependencies between the two countries through VAR-models in first differences (table 8).

Table 6: Johansen trace test for cointegration with three variables: $p^{\mathrm{DE}}, \mathrm{p}^{\mathrm{CH}}, \mathrm{fx}$

\begin{tabular}{|c|c|c|c|c|c|c|c|c|c|c|c|c|}
\hline \multirow[b]{2}{*}{ H0:* } & \multicolumn{4}{|c|}{ Producer Prices } & \multicolumn{5}{|c|}{ Wholesale Prices } & \multicolumn{3}{|c|}{ Critical Values } \\
\hline & $\begin{array}{l}\text { Dairy } \\
\text { milk }\end{array}$ & $\begin{array}{c}\text { All } \\
\text { cheese }\end{array}$ & $\begin{array}{l}\text { Artisan } \\
\text { cheese }\end{array}$ & $\begin{array}{l}\text { Orga- } \\
\text { nic** }\end{array}$ & SMP & WMP & Butter & $\begin{array}{l}\text { Hard } \\
\text { cheese }\end{array}$ & $\begin{array}{l}\text { Semi-hard } \\
\text { cheese }\end{array}$ & $10 \mathrm{pct}$ & $5 \mathrm{pct}$ & $1 \mathrm{pct}$ \\
\hline $\mathrm{r}<=2$ & 0.61 & 0.51 & 2.13 & 5.81 & 1.18 & 0.93 & 1.23 & 0.45 & 0.16 & 7.52 & 9.24 & 12.97 \\
\hline $\mathrm{r}<=1$ & 18.43 & 11.94 & 14.35 & 21.37 & 17.65 & 19.50 & 9.84 & 5.70 & 9.98 & 17.85 & 19.96 & 24.60 \\
\hline$r=0$ & 53.73 & 57.02 & 47.74 & 40.74 & 92.93 & 93.61 & 23.69 & 26.42 & 29.15 & 32.00 & 34.91 & 41.07 \\
\hline $\begin{array}{l}\text { Result } \\
\text { (5\% sign.) }\end{array}$ & $\mathrm{r}=1$ & $\mathrm{r}=1$ & $\mathrm{r}=1$ & $\mathrm{r}=0$ & $\mathrm{r}=1$ & $\mathrm{r}=1$ & $\mathrm{r}=0$ & $\mathrm{r}=0$ & $\mathrm{r}=0$ & & & \\
\hline
\end{tabular}

* $\mathrm{r}=\mathrm{rank}, * *$ tested against German organic producer price, all others against conventional producer price. Including constant in cointegration, all prices in logarithms, lag length acc. to BIC, seasonality considered through monthly dummies (sd1-11).

\subsection{Raw milk price results}

There is strong evidence of cointegration for all conventional raw milk price pairs. Dairy milk shows a higher long-run price transmission elasticity (72\%) than milk for general cheese processing (54\%) and artisanal cheese processing (46\%). In all cases, only Swiss prices adapt to this joint equilibrium at a rather low speed; for dairy milk and artisanal cheese $9 \%$ of the disequilibrium is corrected within one month, for all cheese processing $11 \%$. The exchange rate pass-through varies between 31\% (dairy) and 39\% (artisanal cheese).

For organic raw milk, no cointegration between Swiss and German prices is detected through Johansen trace tests. Therefore, we apply the VAR specification to assess short-term dependencies between the variables. This model finds autocorrelation and seasonal patterns, and surprisingly some influence of the lagged Swiss price change on the German price change $(\triangle C H . l 2=-0.15$, , see table 8$)$. Yet, the statistical significance is not very strong, and the negative sign implies a movement in opposite directions. 


\section{Table 7: Selected key parameters of VECM specification for cointegrated Swiss and German prices with endogenous exchange rate}

\begin{tabular}{|c|c|c|c|c|c|c|c|c|c|c|}
\hline \multirow{2}{*}{\multicolumn{2}{|c|}{$\begin{array}{l}\text { Included endogenous } \\
\text { variables }(+\mathrm{fx})\end{array}$}} & \multicolumn{3}{|c|}{$\begin{array}{c}\text { Long Run Factors } \\
\text { (Cointegrating vector beta, } \\
\text { normalized to } \mathrm{CH} \text {-price) }\end{array}$} & \multicolumn{3}{|c|}{$\begin{array}{l}\text { Short Run Adjustment } \\
\text { (Error correction terms) }\end{array}$} & \multicolumn{3}{|c|}{ Model Fit } \\
\hline & & $\begin{array}{c}\quad \beta_{D E} \\
\text { (PT elast) }\end{array}$ & $\begin{array}{c}\beta_{F X} \\
\text { (FX elast) }\end{array}$ & $\begin{array}{c}\beta_{0} \\
(\text { const })\end{array}$ & $\begin{array}{c}\alpha_{C H} \\
(\text { ect } \mathrm{CH})\end{array}$ & $\begin{array}{c}\alpha_{D E} \\
(\text { ect DE) }\end{array}$ & $\begin{array}{c}\alpha_{F X} \\
(\text { ect FX) }\end{array}$ & $\begin{array}{l}\text { adj.R } \mathrm{R}^{2} \\
\mathrm{CH}-\mathrm{equ} .\end{array}$ & $\begin{array}{c}\text { adj.R }{ }^{2} \\
\text { DE-equ. }\end{array}$ & $\begin{array}{l}\text { adj. } R^{2} \\
\text { fx-equ. }\end{array}$ \\
\hline \multicolumn{11}{|c|}{ Raw milk } \\
\hline DE: & CH: & & & & & & & & & \\
\hline avg & dairy milk & $0.72 * * *$ & $0.31 *$ & $1.70 * * *$ & $-0.09 * * *$ & 0.05 . & -0.01 & 0.54 & 0.54 & -0.01 \\
\hline avg & cheese milk (all) & $0.54 * * *$ & $0.34^{* *}$ & $2.37 * * *$ & $-0.11^{* * *}$ & 0.06 . & -0.02 & 0.64 & 0.54 & -0.01 \\
\hline avg & $\begin{array}{l}\text { cheese milk } \\
\text { (art.) }\end{array}$ & $0.46^{* *}$ & $0.39 *$ & $2.58 * * *$ & $-0.09 * * *$ & 0.00 & -0.00 & 0.36 & 0.51 & 0.00 \\
\hline
\end{tabular}

\section{Processed products}

DE: $\quad \mathrm{CH}:$

\begin{tabular}{llllllllll}
\hline $\mathrm{SMP}$ & $\mathrm{SMP}$ & $0.04 *$ & $0.27 *$ & $1.38^{* *}$ & $-0.38^{* * *}-0.13$ & -0.01 & 0.33 & 0.37 & 0.04 \\
$\mathrm{WMP}$ & $\mathrm{WMP}$ & $0.08^{* *}$ & 0.08 & $1.76^{* * *}$ & $-0.26^{* * *}-0.25 *$ & -0.06 & 0.37 & 0.48 & 0.05 \\
\hline
\end{tabular}

Signif. codes: 0 “***’ 0.001 '**’ 0.01 '*’ 0.05 '.' 0.1 ' ' $1, \beta$-values stated with reverse sign

Exog. variables: monthly dummies, policy dummies for EU-quota end and freetrade, lag selection: Schwarz criterion $(\mathrm{k}=2$ for artisanal cheese milk, 3 for all other variables), all prices in logarithmic transformation. For the full model with all parameter estimates and information on model fit, see appendix (tables A1-A5).

\subsection{Wholesale price results}

Among the analyzed wholesale prices, there is evidence of cointegration for skimmed and whole milk powder. While this relationship is statistically significant, the long-run price transmission elasticity is weak ( $4 \%$ and $8 \%$ ), i.e., hardly any variation of or shock in the German price is passed on to the Swiss price. The VECM specification suggests that Swiss prices follow German prices, as only the Swiss price changes in response to disequilibria ( $\alpha_{C H}=-0.38$ for SMP, -0.26 for WMP) $)^{3}$. For WMP, also $\alpha_{D E}$ is significant, but here the negative sign indicates an error-amplifying rather than an error-correcting behavior. Hence, the Swiss adjustment towards, and the German movement against the join equilibrium relationship would largely cancel each other out, leaving little net error correction.

3 To ensure error-correcting behavior, negative signs are expected for $\alpha_{C H}$, and positive signs for $\alpha_{D E}$ and $\alpha_{f x}$ (see VECM specified in equation (1) or Greb et al. (2013) for more details about restrictions on the $\alpha$ parameters). 
Butter, as well as hard- and semi-hard cheese display no long-run price relationship between the two countries. The VAR-models reveal some minor short-term interactions between Swiss and German prices and exchange rate changes: The Swiss hard cheese price is positively influenced by the previous month's German price change $(\Delta D E . l 1=0.22)$. Yet, this effect is only significant at the $10 \%$ level. For semi-hard cheese, there is some influence of exchange rate changes on Swiss and German price changes $\left(\triangle F X . l 1=0.55^{* * *}\right.$ and $0.29^{*}$ in the Swiss and German equation, respectively). German prices display a strong positive autoregressive behavior for all products, whereas Swiss prices show no (butter) or even a negative influence of past price changes (cheese).

Table 8: Selected key parameters of VAR(FD) specification for non-cointegrated Swiss and German prices with endogenous exchange rate

\begin{tabular}{|c|c|c|c|c|c|c|c|c|c|c|c|c|}
\hline & \multicolumn{6}{|c|}{ CH-equation } & \multicolumn{6}{|c|}{ DE-equation } \\
\hline & $\triangle \mathrm{DE}$. & $\Delta \mathrm{DE}$ & $\Delta \mathrm{CH}$ & $\Delta \mathrm{CH}$ & $\Delta \mathrm{FX}$ & $\Delta \mathrm{FX}$. & $\Delta \mathrm{DE}$ & $\Delta \mathrm{DE}$ & $\Delta \mathrm{CH}$. & $\Delta \mathrm{CH}$. & $\Delta \mathrm{FX}$ & $\Delta \mathrm{FX}$ \\
\hline & 11 & 12 & 11 & 12 & 11 & 12 & 11 & 12 & 11 & 12 & 11 & 12 \\
\hline \multicolumn{13}{|l|}{ Raw milk } \\
\hline Organic & 0.03 & 0.26 & $-0.31^{* *}$ & -0.00 & 0.02 & 0.08 & $0.47^{* * *}$ & $0.43 * * *$ & -0.06 & $-0.15 *$ & 0.07 & -0.09 \\
\hline \multicolumn{13}{|c|}{ Processed products } \\
\hline Butter & 0.02 & $\mathrm{n} / \mathrm{a}$ & -0.02 & $\mathrm{n} / \mathrm{a}$ & -0.07 & $\mathrm{n} / \mathrm{a}$ & $0.47 * * *$ & $\mathrm{n} / \mathrm{a}$ & -0.55 & $\mathrm{n} / \mathrm{a}$ & 0.05 & $\mathrm{n} / \mathrm{a}$ \\
\hline Semi-hard cheese & 0.09 & 0.04 & $-0.76^{* * *}$ & $-0.46^{* * *}$ & $0.55^{* * *}$ & 0.11 & $0.47^{* * *}$ & 0.02 & -0.12 . & -0.15 . & $0.29 *$ & 0.07 \\
\hline Hard cheese & 0.22 . & -0.03 & $-0.40 * * *$ & $-0.29 * * *$ & 0.24 & 0.09 & $0.34^{* * *}$ & 0.08 & 0.02 & 0.04 & -0.05 & -0.06 \\
\hline
\end{tabular}

Signif. codes: 0 “*** 0.001 '**' 0.01 '*’ 0.05 '? 0.1 ' ' 1 , all variables in first differences and logarithmic transformation FX-equation not included here, as no effects from $\mathrm{DE}$ or $\mathrm{CH}$ prices were detected. For the full model with all parameter estimates and information on model fit, see appendix (tables A6-A9).

\subsection{Robustness checks ${ }^{4}$}

Our results also hold if we control for subsidy changes. Adjusting for changes in the processing aid for cheese, we come up with similar results. However, as there have been compensations and shifts between different subsidies, especially direct payments, we chose not to model single subsidy changes in the main model presented here. Further, these subsidies only explain a level difference in prices, but not the different degrees of price transmission.

\footnotetext{
4 Results of alternative model specifications are available upon request.
} 
For cheese and raw milk intended for cheese processing, we also estimated price transmission separately for the subsamples before and after trade liberalization in July 2007. Results show that the long-run price transmission elasticity and the speed of adjustment increased after the trade liberalization. However, we cannot clearly attribute this to the policy change because the global price spikes in 2008 and subsequently increased overall volatility occurred chronologically soon after the policy change.

Converting all prices into one currency and excluding the exchange rate leads to the same conclusions regarding cointegration and the dependency on German prices, but increases the estimates of the price transmission elasticities. In models with two endogenous variables only, it is possible to test for threshold effects, as done in many recent price transmission studies (e.g., Djuric et al. 2015, Hu and Brorsen 2017). In this two-variable specification, we test for threshold cointegration and estimate (Momentum) Threshold Autoregression models (TAR/MTAR). However, we find only weak evidence for threshold effects, depending on the exact model specification and the type of threshold tests applied. Furthermore, eliminating the exchange rate from the estimation model is equivalent to assuming 100\% exchange rate pass-through, which is clearly rejected by our data (see above). Hence, we decided not to pursue the threshold model further.

\section{Discussion}

Our results show that German prices influence Swiss prices for raw milk producer prices more than for processed products' wholesale prices. On both levels, this price pass-through from Germany to Switzerland is higher in the tariff-protected industrial dairy processing channel than for liberalized cheese products. We interpret this as evidence that qualitative product differentiation contributes more than public border protection to segment the Swiss market from the surrounding EU market.

\subsection{The role of border protection}

We find that in the analyzed case, public border protection and trade policies are not the decisive factor. Cheese trade between Switzerland and the EU is liberalized, but we find that Swiss prices for hard- and semi-hard cheese are nevertheless independent of German price developments and exchange rate changes. However, some long-run spatial price transmission is detected for skimmed and whole milk powder. Given that the protected dairy products are more homogeneous than cheese, this cannot be directly compared. Further, we have no counterfactual for the same products without the tariffs or TRQs, so no precise effect can be attributed to these 
policies. Public policies probably help to prevent more complete price transmission on the wholesale level and to maintain the level gap between domestic and foreign prices.

On producer price level, however, trade measures seem to lose their protective function. Prices for raw milk processed into protected dairy products are more strongly influenced by German price developments than raw milk for cheese production. A level difference between these two types of raw milk can partly be explained through targeted subsidies (Finger et al. 2017), but not the fact that farmers supplying milk to the dairy processing channels are more exposed to foreign price shocks than farmers supplying cheese dairies.

We also find that trade volumes only play a minor role in explaining price transmission. There are high long-run price transmission elasticities (46-72\%) in non-traded raw milk, but only low, if any, price transmission (elasticity $<10 \%$ ) for traded products at the wholesale level. This is rather surprising and may support the hypothesis that not only physical trade flows, but also information flows matter for market integration (Stephens et al. 2012). Since information on foreign dairy markets is available to and analyzed both by public and private Swiss actors, we can assume that information does flow and is reacted upon at all times. Hence, processors and traders observe surrounding EU markets and pass on these signals to their Swiss suppliers, even though they do not compete directly, and do not adjust wholesale prices on the domestic markets for protected dairy products.

This mechanism may be supported by the private Swiss national milk market organization, IP Lait, which publishes monthly indicative prices for different milk segments (IP Lait 2017). It is not fully transparent how these indicative prices are set, but they very likely also consider world market and European price developments (for details, see FOAG 2017). These prices are non-binding, and effectively paid prices do not follow them strictly (FOAG 2017). Yet, all major processors are members of this organization and in both public debates about "fair" milk prices and sector-internal benchmarkings these indicative prices are frequently taken as reference points, making them a relevant price signal (e.g., PSL 2018).

Alternatively, one may also interpret this passing on of price signals to producers as indirect arbitrage, as processors do compete with EU products when exporting goods such as milk powder to world markets. Even through Germany and Switzerland barely trade fluid milk or milk powder between one another, they do both export milk powder to third countries, where they compete with one another. 


\subsection{The role of qualitative product characteristics}

Our results suggest that qualitative differentiation limits spatial price transmission between Switzerland and Germany. This differentiation can refer to raw milk (e.g., organic production, silage-free feeding) or the actual product processing (artisanal production, specialty brands). It seems that both types of differentiation are closely linked, i.e., high-quality raw milk is processed into highly differentiated end-products, and it is not possible to disentangle which contributes more to reduce substitutability and to stabilize prices. On the producer level, prices of differentiated raw milk are linked less strongly to European price developments than raw milk intended for industrial dairy products. This also holds when controlling for subsidies, e.g., for processing into cheese, silage-free feeding, or organic production.

Hence, long-run price transmission elasticities and short-run adjustments between German and Swiss milk markets appear to be determined not primarily by the type or degree of public border protection or the physical trade volume, but rather by product characteristics that reduce the international substitutability, such as specialty cheese and organic products.

\subsection{Limitations}

Our results should be interpreted with caution, as our contribution is only a partial assessment of complex price setting processes. We analyze aggregated price data and do not account for structural market differences between and within the analyzed countries. Particularly, we do not consider the role of value chain characteristics, such as contracts, governance structures, and market concentration. Yet, these factors certainly affect market prices and ultimately price transmission estimates. While our discussion stresses the aspects of border protection and qualitative differentiation, these are not the only explanations for the observed price transmission behavior.

\section{Conclusion}

If the aim is to protect raw milk prices against foreign price shocks and to stabilize producer prices, we show that quality differentiation may be an alternative to public trade restrictions. This alternative positioning via high quality can support domestic production without government intervention and without generating the deadweight welfare losses that are associated with tariffs. Hence, producers and processors themselves can take action and implement strategies to compete via quality characteristics rather than the price. Yet, as it takes bundled efforts along the value chain, governmental bodies could help to position Swiss products accordingly. Promoting Swissness as a brand could help the products to gain visibility, to be perceived as high- 
quality, and to ultimately stay competitive in domestic and international markets. First steps have been taken with the implementation of Swissness legislation, which stipulates that products labeled as Swiss must contain a significant share of Swiss raw ingredients (as much as $100 \%$ for milk products). Our study provides evidence that a policy focus on such a quality strategy, i.e., promoting less easily substitutable domestic products, may be more effective than protectionism via tariff barriers. An integrated value chain approach, coordinating differentiation efforts across milk production, processing and retail stage could ensure that farmers, producers and consumers benefit alike. This quality can take various forms: organic, animalfriendly, ecological, regional, or traditional, depending on consumption trends. In the end, the consumer has to perceive it as a superior product, resulting in a higher willingness to pay and lower substitution elasticities with foreign products. Since quality is partly a credence attribute, communication and information must be trusted by the consumers.

We conclude that such a positioning is especially appropriate for Switzerland. First, as a small country with large close-by export markets, oversupply should not be a major issue. Second, as a high-income country, there is a large domestic demand for high-quality products. Finally, as high-cost country, there is a certain necessity to compete via quality, not via the price. 


\section{References}

Abdulai, A. (2000). Spatial price transmission and asymmetry in the Ghanaian maize market. Journal of development economics, 63(2), 327-349.

Acosta, A., Ihle, R., and Robles, M. (2014). Spatial price transmission of soaring milk prices from global to domestic markets. Agribusiness, 30(1), 64-73.

Bakucs, Z., Fertő, I., Benedek, Z., and Molnar, A. (2015). Determinants of Horizontal Milk Producer Price Integration. In 2015 Conference, August 9-14, 2015, Milan, Italy (No. 212042). International Association of Agricultural Economists.

Balcombe, K., Bailey, A., and Brooks, J. (2007). Threshold effects in price transmission: the case of Brazilian wheat, maize, and soya prices. American Journal of Agricultural Economics, 89(2), 308-323.

Benedek, Z., Bakucs, Z., Fałkowski, J., and Fertő, I. (2017) Intra-European Union trade of dairy products: insights from network analysis. Studies in Agricultural Economics, 119 (2), 91-97.

Bolliger, C., and Reviron, S. (2008). Consumer willingness to pay for Swiss chicken meat: an in-store survey to link stated and revealed buying behaviour. In 12th Congress of the European Association of Agricultural Economists (EAAE), Ghent, Belgium.

Bolliger, C. (2011). Assessing Consumers' Cognitive, Affective and Normative Associations on Willingness-to-pay for Domestic Foods. In13th Congress of the European Association of Agricultural Economists (EAAE), Zurich, Switzerland.

Bonnet, C., Corre, T., and Réquillart, V. (2015). Food price dynamics and price adjustment in the EU. In McCorriston, S., (editor). Chapter 4, Price transmission in food chains: the case of the dairy industry. New York: Oxford University Press, 65-101.

Bio Suisse (2015). Standards for the Production, Processing and Trade of 'Bud' Products. Available at https://www.bio-suisse.ch/media/VundH/Regelwerk/EN/rl_2015_e_teil_i_ 08.07.2015.pdf, last accessed 10 August 2019.

Callon, M., Méadel, C., and Rabeharisoa, V. (2002). The economy of qualities. Economy and society, 31(2), 194-217. 
Carvalho, G.R., Bessler, D., Hemme, T., and Schroer-Merker, E. (2015). Understanding Internal Milk Price Relationships. Annual meeting of Southern Agricultural Economics Association. Atlanta, GA. February 2015.

Chen, Y., Hu, X., and Li, S. (2017). Quality differentiation and firms' choices between online and physical markets. International Journal of Industrial Organization, 52, 96-132.

Conforti, P. (2004). Price transmission in selected agricultural markets. FAO Commodity and trade policy research working paper, 7.

Djuric, I., Götz, L., and Glauben, T. (2015). Are export restrictions an effective instrument to insulate domestic prices against skyrocketing world market prices? The wheat export ban in Serbia. Agribusiness, 31(2), 215-228.

Esposti, R., and Listorti, G. (2013). Agricultural price transmission across space and commodities during price bubbles. Agricultural Economics, 44(1), 125-139.

Esposti, R., and Listorti, G. (2018). Price transmission in the Swiss wheat market: does sophisticated border protection make the difference? The International Trade Journal, 32(2), 209-238.

Evans, C. L. (2001). Home Bias in Trade: Location or Foreign-ness? Federal Reserve Bank of New York, Staff Reports, May, Number 128.

Fackler, P.L., and Goodwin, B.K. (2001). Spatial price analysis. In B. Gardner and G. Rausser (eds), Handbook of agricultural economics. Vol. 1, Amsterdam: Elsevier. 971-1024.

Finger, R., Listorti, G., and Tonini, A. (2017). The Swiss payment for milk processed into cheese: ex post and ex ante analysis. Agricultural Economics, 48(4), 437- 448.

Flury, C., Sorg, L., and Giuliani, G. (2014). Evaluation der Zulagen für verkäste Milch und für Fütterung ohne Silage. Flury \& Giuliani Sàrl, Zurich. Available at https://ext.d-nsbpp.admin.ch/NSBExterneStudien/externestudien/419/fr/1624.pdf, last accessed 25 October 2018 .

FOAG (Federal Office for Agriculture) (2015). Bedeutung der Herkunft von Schweizer Landwirtschaftsprodukten. Bern, 15.Juli 2015. Available at https://www.newsd.admin.ch/newsd/NSBExterneStudien/617/attachment/de/2508.pdf, last accessed 25 October 2018 . 
FOAG (Federal Office for Agriculture) (2017). Perspektiven im Milchmarkt. Bericht des Bundesrates in Erfüllung des Postulats 15.3380 der Kommission für Wirtschaft und Abgaben des Nationalrats vom 14.4.2015. Bern, 5. April 2017.

Fousekis, P., and Trachanas, E. (2016). Price transmission in the international skim milk powder markets. Applied Economics, 48(54), 5233-5245.

Goodwin, B. K., and Piggott, N. E. (2001). Spatial market integration in the presence of threshold effects. American Journal of Agricultural Economics, 83(2), 302-317.

Greb, F., von Cramon-Taubadel, S., Krivobokova, T., and Munk, A. (2013). The estimation of threshold models in price transmission analysis. American Journal of Agricultural Economics, 95(4), 900-916.

Grunert, K. G. (2005). Food quality and safety: consumer perception and demand. European Review of Agricultural Economics, 32(3), 369-391.

Hallak, J. C. (2006). Product quality and the direction of trade. Journal of International Economics, 68(1), 238-265.

Haller, T. (2014). Abolition of the Milk Quota System in Switzerland. Burgdorf: Berner Fachhochschule.

Hassouneh, I., von Cramon-Taubadel, S., Serra, T., and Gil, J. M. (2012). Recent developments in the econometric analysis of price transmission. TRANSFOP (Transparency of Food Pricing) Working Paper (2).

Hemme, T., Uddin, M. M., and Ndambi, o. A. (2014). Benchmarking cost of milk production in 46 countries. Journal of Reviews on Global Economics, 3, 254-270.

Hendry, D. F., and Juselius, K. (2001). Explaining cointegration analysis: Part II. The Energy Journal, 22(1), 75-120.

Hillberry, R., and Hummels, D. (2003). Intranational home bias: Some explanations. Review of Economics and Statistics, 85(4), 1089-1092.

Hillberry, R., and Hummels, D. (2008). Trade responses to geographic frictions: A decomposition using micro-data. European Economic Review, 52(3), 527-550. 
Hu, Z., and Brorsen, B. W. (2017). Spatial Price Transmission and Efficiency in the Urea Market. Agribusiness, 33(1), 98-115.

Hummels, D. (1999). Towards a Geography of Trade Costs, University of Chicago. Available at http://dx.doi.org/10.2139/ssrn.160533, last accessed 10 August 2019.

IFCN (2011). Dairy report 2011. IFCN Dairy Research Center at CAU Kiel, Faculty of Agricultural and Nutritional Sciences, Germany.

IP Lait (2017). Reglement für den Standardvertrag und für die Modalitäten zum Erst- und Zweitmilchkauf und zur Segmentierung (Fassung vom 24. 11. 2017). Available at https://www.ip-lait.ch/171124_Reglement_Standardvertrag.pdf, last accessed $10 \mathrm{Au}-$ gust 2019.

Johansen, S. (1988). Statistical analysis of cointegrating vectors. Journal of Economic Dynamics and Control, 12, 231-254.

Koch, A. (2002). Evaluation der Schweizer Agrarmarktpolitik unter besonderer Berücksichtigung von Unsicherheit. ETH Zürich, ETH Diss Nr. 14505.

Li, X., Lopez, R. A., and Wang, R. (2018). Energy price shocks and milk price adjustments. Applied Economics Letters, 25(4), 268-271.

Liefert, W., and Persaud, S. (2009). The transmission of exchange rate changes to agricultural prices. Economic Research Report, 76, USDA.

Limao, N., and Venables, A. J. (2001). Infrastructure, geographical disadvantage, transport costs, and trade. The World Bank Economic Review, 15(3), 451-479.

Loi, A., Esposti, R., Gentile, M. et al. (2016), Policy evaluation of tariff rate quotas. Report mandated by the Swiss federal Office of Agriculture. Arete, Bologna.

Loy, J. P., Holm, T., Steinhagen, C., and Glauben, T. (2015). Cost pass-through in differentiated product markets: a disaggregated study for milk and butter. European Review of Agricultural Economics, 42(3), 441-471.

Mann, S., and Gairing, M. (2011). Post milk quota experiences in Switzerland. EuroChoices, $10,16-21$. 
Morris, C., and Young, C. (2000). 'Seed to shelf', 'teat to table', 'barley to beer' and 'womb to tomb': discourses of food quality and quality assurance schemes in the UK. Journal of Rural Studies, 16(1), 103-115.

Newey, W. K., and West, K. D. (1987). A simple, positive semi-definite, heteroskedasticity and autocorrelation consistent covariance matrix. Econometrica, 55(3), 703-708.

Newton, J. (2016). Price transmission in global dairy markets. International Food and Agribusiness Management Review, 19(B), 57-71.

Phillips, P. C., and Perron, P. (1988). Testing for a unit root in time series regression. Biometrika, 75(2), 335-346.

PSL (Producteurs Suisses de Lait) (2018). Milchpreismonitoring, Report March 2018. Available at https://www.swissmilk.ch/de/produzenten/milchmarkt/marktentwicklung/milch preisvergleich/aktuelle-milchpreise/-dl-/fileadmin/filemount/uploads/content/berichtsmp-milchpreis-monitoring-2018-maerz-auswertung-2018-05-24-de.pdf, last accessed 25 October 2018.

Rosen, S. (1974). Hedonic prices and implicit markets: product differentiation in pure competition. Journal of political economy, 82(1), 34-55.

Shaked, A., and Sutton, J. (1982). Relaxing price competition through product differentiation. The Review of Economic Studies, 49(1), 3-13.

Stephens, E., Mabaya, E., von Cramon-Taubadel, S., and Barrett, C. B. (2012). Spatial price adjustment with and without trade. Oxford Bulletin of Economics and Statistics, 74(3), 453-469.

Stræte, E.P. (2008). Modes of qualities in development of speciality food. British Food Journal, $110(1), 62-75$

Swiss Federal Council (2011). Regulation on imports of agricultural products (Agricultural Import Regulation, AEV) of 26 Oktober 2011 (Status as of 1 January 2018). SR 916.01.

Swiss Federal Council (2017). Federal Act on the Protection of Trade Marks and Indications of Source (Trade Mark Protection Act, TmPA) of 28 August 1992 (Status as of 1 January 2017). SR 232.11. 
Swiss Federal Department of Economic Affairs (1999). Verordnung über die Qualitätssicherung bei der gewerblichen Milchverarbeitung, vom 13. April 1999. SR916.351.021.3.

TSM, SMP, SCM, and Agristat (2017). Milchstatistik der Schweiz 2016. Bern, September 2017, ISSN 1423- 4548.

von Cramon-Taubadel, S. (2017). The analysis of market integration and price transmissionresults and implications in an African context. Agrekon, 56(2), 83-96.

Zhang, J., Brown, C., Dong, X., and Waldron, S. (2017). Price transmission in whole milk powder markets: implications for the Oceania dairy sector of changing market developments. New Zealand Journal of Agricultural Research, 60(2), 140-153.

Zivot, E., and Andrews, D.W.K. (1992). Further Evidence on the Great Crash, the Oil-Price Shock, and the Unit-Root Hypothesis, Journal of Business \& Economic Statistics, 10(3), $251-270$. 


\section{Appendix (Full Model Specifications)}

\section{a) Vector Error Correction Models for cointegrated prices}

Table A1 (Dairy milk): VECM with Swiss producer prices for dairy processing, German conventional producer price and exchange rate

\begin{tabular}{|c|c|c|c|c|c|c|c|c|c|}
\hline \multirow[b]{3}{*}{ ect1 } & \multicolumn{3}{|c|}{ Response CH Price } & \multicolumn{3}{|c|}{ Response DE Price } & \multicolumn{3}{|c|}{ Response Exchange Rate: } \\
\hline & \multirow{2}{*}{$\begin{array}{r}\text { Estimate } \mathrm{S} \\
-0.088\end{array}$} & \multirow{2}{*}{$\begin{array}{r}\text { Std.Error } \mathrm{P} \\
0.019\end{array}$} & \multirow{2}{*}{$\frac{\operatorname{Pr}(>|t|)}{0.000^{* * *}}$} & \multirow{2}{*}{$\begin{array}{r}\text { Estimate } S \\
0.054\end{array}$} & \multicolumn{2}{|c|}{ Std.Error $\operatorname{Pr}(>|t|)$} & \multicolumn{2}{|c|}{ Estimate Std.Error } & $\operatorname{Pr}(>|t|)$ \\
\hline & & & & & 0.028 & 0.056 . & -0.010 & 0.016 & 0.518 \\
\hline Quota.EU & 0.005 & 0.004 & 0.266 & -0.003 & 0.006 & 0.569 & 0.005 & 0.003 & 0.127 \\
\hline Freetrade & -0.017 & 0.004 & $0.000 * * *$ & 0.012 & 0.005 & $0.035^{*}$ & -0.006 & 0.003 & 0.053 . \\
\hline $\operatorname{sd} 1$ & -0.002 & 0.007 & 0.747 & 0.003 & 0.010 & 0.780 & -0.007 & 0.005 & 0.230 \\
\hline $\mathrm{sd} 2$ & 0.000 & 0.007 & 0.990 & 0.032 & 0.010 & $0.002 * *$ & -0.002 & 0.006 & 0.753 \\
\hline $\mathrm{sd} 3$ & -0.008 & 0.007 & 0.230 & 0.034 & 0.010 & $0.001 * * *$ & -0.003 & 0.006 & 0.590 \\
\hline $\mathrm{sd} 4$ & -0.008 & 0.007 & 0.219 & 0.029 & 0.010 & $0.004 * *$ & 0.000 & 0.006 & 0.972 \\
\hline sd5 & -0.002 & 0.007 & 0.790 & 0.027 & 0.010 & $0.007^{* *}$ & -0.003 & 0.006 & 0.561 \\
\hline sd6 & 0.047 & 0.007 & $0.000 * * *$ & 0.040 & 0.010 & $0.000 * * *$ & -0.007 & 0.006 & 0.229 \\
\hline $\operatorname{sd} 7$ & 0.035 & 0.008 & $0.000 * * *$ & 0.040 & 0.012 & $0.001 * * *$ & 0.000 & 0.007 & 0.984 \\
\hline $\operatorname{sd} 8$ & 0.031 & 0.008 & $0.000 * * *$ & 0.045 & 0.012 & $0.000 * * *$ & -0.002 & 0.007 & 0.821 \\
\hline sd9 & 0.025 & 0.008 & $0.001 * *$ & 0.052 & 0.011 & $0.000^{* * *}$ & 0.009 & 0.006 & 0.157 \\
\hline $\operatorname{sd} 10$ & 0.014 & 0.007 & $0.045^{*}$ & 0.051 & 0.010 & $0.000 * * *$ & 0.004 & 0.006 & 0.502 \\
\hline $\operatorname{sd} 11$ & -0.014 & 0.006 & $0.034^{*}$ & 0.026 & 0.009 & $0.005 * *$ & 0.001 & 0.005 & 0.852 \\
\hline $\begin{array}{l}\mathrm{CH} \text { _prod.dai } \\
\text { ry.d1l }\end{array}$ & -0.108 & 0.077 & 0.165 & 0.244 & 0.112 & $0.031^{*}$ & -0.020 & 0.064 & 0.751 \\
\hline DE_prod.dl1 & 0.151 & 0.054 & $0.006^{* *}$ & 0.297 & 0.079 & $0.000 * * *$ & 0.001 & 0.045 & 0.985 \\
\hline fx.dl1 & 0.250 & 0.089 & $0.006^{* *}$ & 0.062 & 0.130 & 0.633 & 0.098 & 0.074 & 0.188 \\
\hline $\begin{array}{l}\mathrm{CH} \text { _prod.dai } \\
\text { ry.d12 }\end{array}$ & -0.194 & 0.080 & $0.016^{*}$ & 0.032 & 0.116 & 0.784 & -0.042 & 0.067 & 0.533 \\
\hline DE_prod.dl2 & 0.163 & 0.055 & $0.004^{* *}$ & 0.199 & 0.080 & $0.014^{*}$ & -0.016 & 0.046 & 0.728 \\
\hline fx.d12 & 0.118 & 0.091 & 0.197 & -0.062 & 0.133 & 0.642 & -0.045 & 0.076 & 0.550 \\
\hline $\begin{array}{l}\mathrm{CH} \text { _prod.dai } \\
\text { ry.dl3 }\end{array}$ & -0.072 & 0.078 & 0.359 & 0.045 & 0.113 & 0.691 & -0.110 & 0.065 & 0.092 \\
\hline DE_prod.dl3 & 0.044 & 0.052 & 0.399 & 0.008 & 0.076 & 0.914 & 0.034 & 0.043 & 0.437 \\
\hline fx.dl3 & 0.171 & 0.090 & 0.060 & -0.037 & 0.132 & 0.777 & 0.099 & 0.075 & 0.189 \\
\hline $\begin{array}{l}\text { Resid. st. er- } \\
\text { ror }\end{array}$ & 0.017 on 18 & $80 \mathrm{DF}$ & & 0.025 on 18 & $80 \mathrm{DF}$ & & 0.014 on 1 & & \\
\hline Mult. R-squ & 0.598 & & & 0.593 & & & 0.112 & & \\
\hline Adj. R-squ & 0.544 & & & 0.539 & & & -0.006 & & \\
\hline F-stat & 11.15 on 24 & 4 and $180 \mathrm{D}$ & & 10.94 on 24 & 4 and $180 \mathrm{D}$ & & 0.949 on 2 & $180 \mathrm{DF}$ & \\
\hline$p$-value & $<2.2 \mathrm{e}-16$ & & & $<2.2 \mathrm{e}-16$ & & & 0.536 & & \\
\hline
\end{tabular}

Beta (coint. vector): $1 \mathrm{CH} \_$prod.dairy $-0.72 \mathrm{DE} \_$prod $-0.31 \mathrm{fx}-1.70$

Signif. codes: 0 ‘*** 0.001 “**, 0.01 ' $*$ ’ 0.05 ‘' 0.1 ', 1 , all variables in logarithmic transformation

$\mathrm{DF}=$ degrees of freedom, $\mathrm{dl}=$ differenced, lagged, ect $=$ error correction term (alpha), Freetrade $=$ cheese-free-trade-dummy:

0 before, 1 after 07/2007, Quota.EU = end-of-EU-quota dummy: 0 before, 1 after 04/2015, sd = seasonal dummy 
Table A2 (Cheese milk): VECM with Swiss producer prices for cheese processing (all), German conventional producer price and exchange rate

\begin{tabular}{|c|c|c|c|c|c|c|c|c|c|c|}
\hline & & Response $\mathrm{CH}$ & H Price & & esponse DE & Price & Respc & e Excha & ange Rate & \\
\hline & Estimate & Std.Error $\mathrm{P}$ & $\operatorname{Pr}(>|t|)$ & Estimate & Std.Error & $\operatorname{Pr}(>|t|)$ & Estimate & 1.Error & $\operatorname{Pr}(>|t|)$ & \\
\hline ect1 & -0.111 & 0.018 & $0.000 * * *$ & 0.055 & 0.040 & 0.171 & -0.021 & 0.023 & 0.373 & \\
\hline Quota.EU & 0.009 & 0.003 & $0.004 * *$ & -0.006 & 0.007 & 0.346 & 0.006 & 0.004 & 0.105 & \\
\hline Freetrade & -0.008 & 0.002 & $0.000 * * *$ & 0.005 & 0.004 & 0.144 & -0.005 & 0.002 & 0.012 & * \\
\hline sd1 & -0.003 & 0.004 & 0.513 & 0.006 & 0.010 & 0.559 & -0.005 & 0.006 & 0.364 & \\
\hline $\mathrm{sd} 2$ & -0.009 & 0.004 & $0.040 *$ & 0.039 & 0.010 & $0.000 * * *$ & 0.000 & 0.006 & 0.976 & \\
\hline $\mathrm{sd} 3$ & -0.013 & 0.005 & $0.005 * *$ & 0.036 & 0.010 & $0.000 * * *$ & -0.004 & 0.006 & 0.458 & \\
\hline $\operatorname{sd} 4$ & -0.007 & 0.004 & 0.111 & 0.028 & 0.010 & $0.004 * *$ & -0.002 & 0.006 & 0.730 & \\
\hline $\operatorname{sd} 5$ & -0.001 & 0.004 & 0.751 & 0.026 & 0.010 & $0.008 * *$ & -0.002 & 0.006 & 0.697 & \\
\hline sd6 & 0.030 & 0.004 & $0.000 * * *$ & 0.043 & 0.010 & $0.000 * * *$ & -0.005 & 0.006 & 0.353 & \\
\hline $\mathrm{sd} 7$ & 0.034 & 0.005 & $0.000 * * *$ & 0.053 & 0.012 & $0.000 * * *$ & 0.003 & 0.007 & 0.652 & \\
\hline $\operatorname{sd} 8$ & 0.035 & 0.005 & $0.000 * * *$ & 0.057 & 0.012 & $0.000 * * *$ & 0.000 & 0.007 & 0.992 & \\
\hline sd9 & 0.028 & 0.005 & $0.000 * * *$ & 0.060 & 0.011 & $0.000 * * *$ & 0.007 & 0.007 & 0.313 & \\
\hline $\operatorname{sd} 10$ & 0.017 & 0.005 & $0.001 * * *$ & 0.059 & 0.011 & $0.000 * * *$ & 0.004 & 0.006 & 0.515 & \\
\hline $\operatorname{sd} 11$ & -0.010 & 0.004 & $0.028 *$ & 0.030 & 0.010 & $0.002 * *$ & 0.001 & 0.006 & 0.834 & \\
\hline $\begin{array}{l}\mathrm{CH} \_ \text {prod.che } \\
\text { ese.dll }\end{array}$ & -0.359 & 0.074 & $0.000 * * *$ & 0.058 & 0.164 & 0.724 & -0.080 & 0.094 & 0.398 & \\
\hline DE_prod.dl1 & 0.073 & 0.033 & $0.028 *$ & 0.361 & 0.073 & $0.000 * * *$ & 0.004 & 0.042 & 0.925 & \\
\hline fx.dl1 & 0.134 & 0.058 & $0.022 *$ & 0.098 & 0.128 & 0.443 & 0.098 & 0.074 & 0.183 & \\
\hline $\begin{array}{l}\mathrm{CH} \text { _prod.che } \\
\text { ese.d12 }\end{array}$ & -0.180 & 0.076 & $0.018 *$ & -0.135 & 0.166 & 0.419 & -0.048 & 0.096 & 0.618 & \\
\hline DE_prod.dl2 & 0.089 & 0.033 & $0.008 * *$ & 0.255 & 0.073 & $0.001 * * *$ & -0.027 & 0.042 & 0.518 & \\
\hline fx.dl2 & 0.059 & 0.059 & 0.320 & -0.007 & 0.129 & 0.959 & -0.037 & 0.074 & 0.623 & \\
\hline $\begin{array}{l}\text { Resid. st. er- } \\
\text { ror }\end{array}$ & 0.011 on 1 & $184 \mathrm{DF}$ & & 0.025 on 18 & $84 \mathrm{DF}$ & & 0.014 on & $4 \mathrm{DF}$ & & \\
\hline Mult. R-squ & 0.677 & & & 0.588 & & & 0.096 & & & \\
\hline Adj. R-squ & 0.641 & & & 0.541 & & & -0.007 & & & \\
\hline F-stat & 18.4 on 21 & 1 and $184 \mathrm{DF}$ & & 12.5 on 21 & and $184 \mathrm{D}$ & & 0.927 on & and 184 & $4 \mathrm{DF}$ & \\
\hline p-value & $<2.2 \mathrm{e}-16$ & & & $<2.2 \mathrm{e}-16$ & & & 0.556 & & & \\
\hline
\end{tabular}

Beta (coint. vector): $1 \mathrm{CH}$ pprod.cheese $-0.54 \mathrm{DE} \_$prod $-0.34 \mathrm{fx}-2.37$

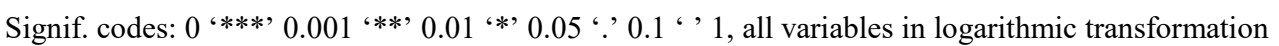

$\mathrm{DF}=$ degrees of freedom, $\mathrm{dl}=$ differenced, lagged, ect $=$ error correction term (alpha), Freetrade $=$ cheese-free-tradedummy: 0 before, 1 after 07/2007, Quota.EU = end-of-EU-quota dummy: 0 before, 1 after 04/2015, sd = seasonal dummy

Table A3 (Artisanal cheese milk): VECM with Swiss producer prices for artisanal cheese processing, German convent. producer price and exchange rate

\begin{tabular}{|c|c|c|c|c|c|}
\hline \multicolumn{3}{|c|}{ Response CH Price } & & Response DE Price & Response Exchange Rate \\
\hline Estimate & $\begin{array}{l}\text { Std.Er- } \\
\text { ror }\end{array}$ & $\begin{array}{l}\operatorname{Pr}(>|t| \\
)\end{array}$ & Estimate & Std.Error $\operatorname{Pr}(>|t|)$ & Estimate Std.Error $\operatorname{Pr}(>|t|)$ \\
\hline
\end{tabular}




\begin{tabular}{|c|c|c|c|c|c|c|c|c|c|}
\hline ect1 & -0.092 & 0.016 & $0.000 * * *$ & 0.004 & 0.040 & 0.922 & -0.003 & 0.022 & 0.884 \\
\hline Quota.EU & 0.010 & 0.003 & $0.001 * *$ & -0.001 & 0.007 & 0.857 & 0.005 & 0.004 & 0.246 \\
\hline Freetrade & -0.001 & 0.001 & 0.569 & 0.003 & 0.003 & 0.290 & -0.004 & 0.002 & $0.015 *$ \\
\hline sd1 & -0.007 & 0.004 & 0.081 . & 0.007 & 0.009 & 0.451 & -0.006 & 0.005 & 0.270 \\
\hline $\mathrm{sd} 2$ & -0.005 & 0.004 & 0.202 & 0.028 & 0.009 & $0.004 * *$ & 0.001 & 0.005 & 0.832 \\
\hline $\mathrm{sd} 3$ & -0.007 & 0.004 & 0.070 & 0.022 & 0.009 & $0.014 *$ & -0.002 & 0.005 & 0.688 \\
\hline sd4 & -0.006 & 0.004 & 0.119 & 0.019 & 0.009 & $0.037 *$ & 0.000 & 0.005 & 0.938 \\
\hline sd5 & 0.001 & 0.004 & 0.736 & 0.018 & 0.009 & $0.047 *$ & 0.000 & 0.005 & 0.923 \\
\hline sd6 & 0.008 & 0.004 & $0.030 *$ & 0.032 & 0.009 & $0.001 * * *$ & -0.004 & 0.005 & 0.384 \\
\hline $\mathrm{sd} 7$ & 0.013 & 0.004 & $0.001 * * *$ & 0.041 & 0.009 & $0.000 * * *$ & 0.001 & 0.005 & 0.784 \\
\hline $\operatorname{sd} 8$ & 0.011 & 0.004 & $0.006 * *$ & 0.042 & 0.009 & $0.000 * * *$ & -0.003 & 0.005 & 0.619 \\
\hline sd9 & 0.016 & 0.004 & $0.000 * * *$ & 0.052 & 0.009 & $0.000 * * *$ & 0.004 & 0.005 & 0.477 \\
\hline $\operatorname{sd} 10$ & 0.010 & 0.004 & $0.010 * *$ & 0.051 & 0.009 & $0.000 * * *$ & 0.001 & 0.005 & 0.809 \\
\hline $\operatorname{sd} 11$ & -0.001 & 0.004 & 0.731 & 0.026 & 0.009 & $0.005 * *$ & -0.001 & 0.005 & 0.860 \\
\hline $\begin{array}{l}\mathrm{CH} \text { _prod.art.che } \\
\text { es.d11 }\end{array}$ & -0.136 & 0.072 & 0.061 & 0.083 & 0.176 & 0.637 & 0.055 & 0.098 & 0.577 \\
\hline DE_prod.dl1 & 0.033 & 0.027 & 0.226 & 0.472 & 0.065 & $0.000 * * *$ & -0.024 & 0.037 & 0.520 \\
\hline fx.dl1 & 0.082 & 0.054 & 0.130 & 0.087 & 0.130 & 0.504 & 0.098 & 0.073 & 0.181 \\
\hline Resid. st. error & \multicolumn{3}{|c|}{0.011 on $188 \mathrm{DF}$} & \multicolumn{3}{|c|}{0.026 on $188 \mathrm{DF}$} & \multicolumn{3}{|c|}{0.014 on $188 \mathrm{DF}$} \\
\hline Mult. R-squ & \multicolumn{3}{|l|}{0.416} & \multicolumn{3}{|l|}{0.557} & \multicolumn{3}{|l|}{0.089} \\
\hline Adj. R-squ & \multicolumn{3}{|l|}{0.360} & \multicolumn{3}{|l|}{0.514} & \multicolumn{3}{|l|}{0.002} \\
\hline F-stat & \multicolumn{3}{|c|}{7.434 on 18 and $188 \mathrm{DF}$} & \multicolumn{3}{|c|}{13.12 on 18 and $188 \mathrm{DF}$} & \multicolumn{3}{|c|}{1.02 on 18 and $188 \mathrm{DF}$} \\
\hline p-value & \multicolumn{3}{|l|}{$2.53 \mathrm{E}-11$} & \multicolumn{3}{|l|}{$<2.2 \mathrm{e}-16$} & \multicolumn{3}{|l|}{0.440} \\
\hline
\end{tabular}

Beta (coint. vector): $1 \mathrm{CH} \_$prod.art.cheese $-0.46 \mathrm{DE} \_$prod $-0.39 \mathrm{fx}-2.58$

Signif. codes: 0 '***' 0.001 '**' $0.01^{\prime *}{ }^{*} 0.05$ '? 0.1 ' ' 1 , all variables in logarithmic transformation

$\mathrm{DF}=$ degrees of freedom, $\mathrm{dl}=$ differenced, lagged, ect $=$ error correction term (alpha), Freetrade $=$ cheese-free-trade-

dummy: 0 before, 1 after 07/2007, Quota.EU = end-of-EU-quota dummy: 0 before, 1 after 04/2015, sd = seasonal dummy

Table A4 (Skimmed Milk Powder): VECM with Swiss and German SMP wholesale price and exchange rate

\begin{tabular}{lccccccccc}
\hline & \multicolumn{3}{c}{ Response CH Price } & \multicolumn{3}{c}{ Response DE Price } & \multicolumn{3}{c}{ Response Exchange Rate } \\
& Estimate & Std.Error & $\operatorname{Pr}(>|t|)$ & Estimate & Std.Error & $\operatorname{Pr}(>|t|)$ & Estimate & Std.Error & $\operatorname{Pr}(>|t|)$ \\
\hline ect1 & -0.384 & 0.045 & $0.000 * * *$ & -0.128 & 0.092 & 0.167 & -0.013 & 0.033 & 0.702 \\
Quota.EU & -0.003 & 0.005 & 0.531 & -0.004 & 0.010 & 0.705 & 0.005 & 0.004 & 0.148 \\
Freetrade & -0.012 & 0.003 & $0.000 * * *$ & -0.003 & 0.005 & 0.628 & -0.005 & 0.002 & $0.011 *$ \\
sd1 & -0.006 & 0.008 & 0.493 & -0.023 & 0.018 & 0.186 & -0.011 & 0.006 & 0.079 \\
sd2 & -0.015 & 0.008 & 0.073 & -0.006 & 0.017 & 0.737 & -0.002 & 0.006 & 0.779 \\
sd3 & -0.014 & 0.009 & 0.092 & -0.030 & 0.018 & 0.089 & -0.006 & 0.006 & 0.315 \\
sd4 & -0.009 & 0.008 & 0.283 & -0.001 & 0.017 & 0.930 & -0.002 & 0.006 & 0.719 \\
sd5 & -0.018 & 0.008 & $0.036 *$ & -0.008 & 0.017 & 0.631 & -0.004 & 0.006 & 0.556 \\
sd6 & -0.014 & 0.008 & 0.100 & -0.009 & 0.017 & 0.626 & -0.011 & 0.006 & 0.078. \\
sd7 & -0.006 & 0.008 & 0.479 & -0.017 & 0.017 & 0.332 & 0.000 & 0.006 & 0.995
\end{tabular}




\begin{tabular}{|c|c|c|c|c|c|c|c|c|c|}
\hline $\operatorname{sd} 8$ & -0.020 & 0.008 & $0.018 *$ & -0.017 & 0.017 & 0.331 & -0.006 & 0.006 & 0.340 \\
\hline sd9 & -0.010 & 0.008 & 0.255 & -0.007 & 0.017 & 0.671 & 0.002 & 0.006 & 0.703 \\
\hline $\operatorname{sd} 10$ & -0.013 & 0.008 & 0.122 & -0.026 & 0.017 & 0.139 & 0.000 & 0.006 & 0.962 \\
\hline sd11 & -0.006 & 0.008 & 0.497 & -0.045 & 0.017 & $0.010 *$ & -0.006 & 0.006 & 0.367 \\
\hline SMP_CH.dl1 & -0.544 & 0.087 & $0.000 * * *$ & -0.299 & 0.181 & 0.102 & -0.085 & 0.064 & 0.188 \\
\hline SMP_DE.dl1 & -0.067 & 0.039 & 0.094 . & 0.734 & 0.082 & $0.000 * * *$ & 0.059 & 0.029 & $0.044 *$ \\
\hline fx.dl1 & 0.084 & 0.117 & 0.477 & 0.221 & 0.243 & 0.366 & 0.138 & 0.086 & 0.113 \\
\hline SMP_CH.dl2 & -0.428 & 0.090 & $0.000 * * *$ & -0.144 & 0.186 & 0.442 & -0.026 & 0.066 & 0.696 \\
\hline SMP_DE.dl2 & -0.046 & 0.041 & 0.268 & -0.362 & 0.086 & $0.000 * * *$ & -0.030 & 0.030 & 0.330 \\
\hline fx.dl2 & -0.037 & 0.114 & 0.746 & 0.238 & 0.236 & 0.315 & -0.089 & 0.084 & 0.289 \\
\hline Resid. st. error & \multicolumn{3}{|c|}{0.021 on $136 \mathrm{DF}$} & \multicolumn{3}{|c|}{0.043 on $136 \mathrm{DF}$} & \multicolumn{3}{|c|}{0.015 on $136 \mathrm{DF}$} \\
\hline Mult. R-squ & \multicolumn{3}{|l|}{0.426} & \multicolumn{3}{|l|}{0.457} & \multicolumn{3}{|l|}{0.172} \\
\hline Adj. R-squ & \multicolumn{3}{|l|}{0.331} & \multicolumn{3}{|l|}{0.373} & \multicolumn{3}{|l|}{0.044} \\
\hline F-stat & \multicolumn{3}{|c|}{4.81 on 21 and $136 \mathrm{DF}$} & \multicolumn{3}{|c|}{5.448 on 21 and $136 \mathrm{DF}$} & \multicolumn{3}{|c|}{1.344 on 21 and $136 \mathrm{DF}$} \\
\hline p-value & \multicolumn{3}{|l|}{$6.72 \mathrm{E}-09$} & \multicolumn{3}{|l|}{$2.988 \mathrm{E}-10$} & \multicolumn{3}{|l|}{0.159} \\
\hline
\end{tabular}

Beta (coint. vector): 1 SMP_CH -0.04 SMP_DE $-0.27 \mathrm{fx}-1.38$

Signif. codes: 0 '***' $0.001^{\prime * * *} 0.01^{\prime *} * 0.05$ '? $0.1^{\prime}$ ' 1 , all variables in logarithmic transformation

$\mathrm{DF}=$ degrees of freedom, $\mathrm{dl}=$ differenced, lagged, ect $=$ error correction term (alpha), Freetrade $=$ cheese-free-trade-

dummy: 0 before, 1 after 07/2007, Quota.EU = end-of-EU-quota dummy: 0 before, 1 after 04/2015, sd = seasonal dummy

\section{Table A5 (Whole Milk Powder): VECM with Swiss and German WMP wholesale price} and exchange rate

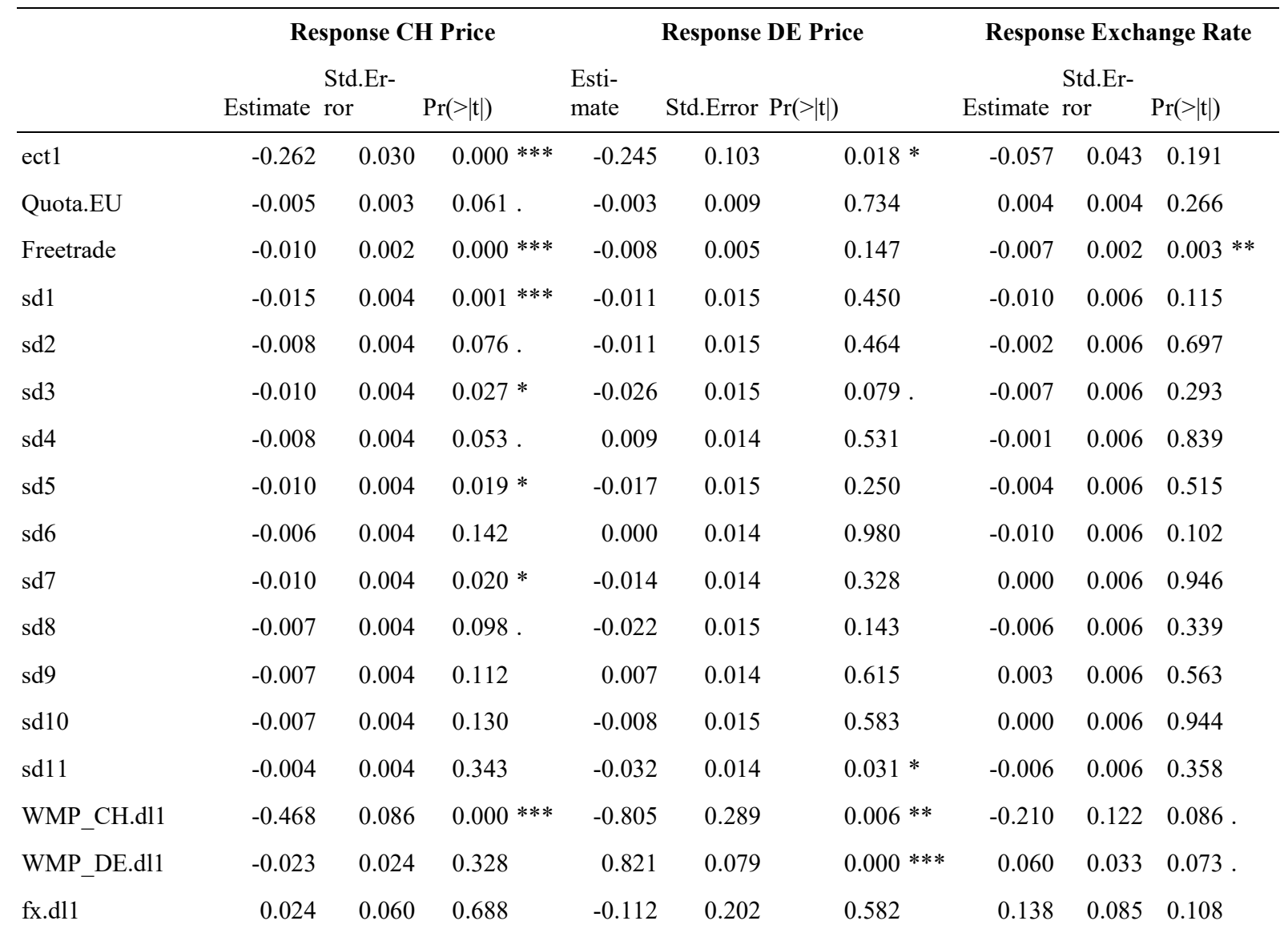




\begin{tabular}{|c|c|c|c|c|c|c|c|c|c|}
\hline WMP_CH.dl2 & -0.369 & 0.087 & $0.000 * * *$ & -0.822 & 0.294 & $0.006 * *$ & -0.225 & 0.124 & 0.072 \\
\hline WMP_DE.d12 & 0.005 & 0.024 & 0.835 & -0.329 & 0.082 & $0.000 * * *$ & -0.052 & 0.035 & 0.133 \\
\hline fx.dl2 & -0.023 & 0.059 & 0.697 & 0.438 & 0.200 & $0.030 *$ & -0.056 & 0.084 & 0.506 \\
\hline Resid. st. error & \multicolumn{3}{|c|}{0.011 on $136 \mathrm{DF}$} & \multicolumn{3}{|c|}{0.036 on $136 \mathrm{DF}$} & \multicolumn{3}{|c|}{0.015 on $136 \mathrm{DF}$} \\
\hline Mult. R-squ & \multicolumn{3}{|l|}{0.456} & \multicolumn{3}{|l|}{0.553} & \multicolumn{3}{|l|}{0.181} \\
\hline Adj. R-squ & \multicolumn{3}{|l|}{0.373} & \multicolumn{3}{|l|}{0.484} & \multicolumn{3}{|l|}{0.054} \\
\hline F-stat & \multicolumn{3}{|c|}{5.438 on 21 and $136 \mathrm{DF}$} & \multicolumn{3}{|c|}{8.016 on 21 and $136 \mathrm{DF}$} & \multicolumn{3}{|c|}{1.434 on 21 and $136 \mathrm{DF}$} \\
\hline$p$-value & \multicolumn{3}{|l|}{$3.14 \mathrm{E}-10$} & \multicolumn{3}{|l|}{$3.01 \mathrm{E}-12$} & \multicolumn{3}{|l|}{0.113} \\
\hline
\end{tabular}

Beta (coint. vector): 1 WMP_CH - 0.08 WMP_DE $-0.08 \mathrm{fx}-1.76$

Signif. codes: 0 “***’ 0.001 '**’ 0.01 '*’ 0.05 '? 0.1 ' ' 1 , all variables in logarithmic transformation

$\mathrm{DF}=$ degrees of freedom, $\mathrm{dl}=$ differenced, lagged, ect= error correction term (alpha), Freetrade $=$ cheese-free-tradedummy: 0 before, 1 after 07/2007, Quota.EU = end-of-EU-quota dummy: 0 before, 1 after 04/2015, sd = seasonal dummy

\section{b) Vector Autoregressive models in first differences for non-cointegrated prices}

Table A6 (Organic raw milk): VAR in first differences with Swiss and German organic milk producer price and exchange rate

\begin{tabular}{|c|c|c|c|c|c|c|c|c|c|c|}
\hline \multirow[b]{3}{*}{ DE.11 } & \multicolumn{3}{|c|}{ CH Equation } & \multicolumn{3}{|c|}{ DE Equation } & \multicolumn{4}{|c|}{ Exchange Rate Equation } \\
\hline & Estimate & Std.Error & $\operatorname{Pr}(>|t|)$ & Estimate & $\begin{array}{l}\text { Std.Er- } \\
\text { ror }\end{array}$ & $\operatorname{Pr}(>|t|)$ & Estimate & Std.Error & $\operatorname{Pr}(>|t|)$ & \\
\hline & 0.027 & 0.149 & 0.856 & 0.472 & 0.100 & $0.000 * * *$ & -0.066 & 0.163 & 0.687 & \\
\hline CH.11 & -0.309 & 0.099 & $0.002 * *$ & -0.060 & 0.066 & 0.368 & -0.010 & 0.108 & 0.930 & \\
\hline FX.11 & 0.015 & 0.092 & 0.871 & 0.067 & 0.062 & 0.277 & 0.113 & 0.100 & 0.262 & \\
\hline DE.12 & 0.256 & 0.158 & 0.107 & 0.432 & 0.105 & $0.000 * * *$ & 0.073 & 0.172 & 0.671 & \\
\hline CH.12 & -0.003 & 0.101 & 0.973 & -0.148 & 0.067 & $0.031 *$ & -0.127 & 0.110 & 0.249 & \\
\hline FX.12 & 0.081 & 0.093 & 0.384 & -0.087 & 0.062 & 0.164 & -0.088 & 0.101 & 0.389 & \\
\hline DE.13 & 0.231 & 0.157 & 0.146 & -0.011 & 0.105 & 0.918 & 0.033 & 0.171 & 0.846 & \\
\hline CH.13 & -0.074 & 0.097 & 0.452 & -0.113 & 0.065 & 0.085 & -0.100 & 0.106 & 0.347 & \\
\hline FX.13 & 0.055 & 0.092 & 0.552 & 0.081 & 0.061 & 0.187 & 0.084 & 0.100 & 0.402 & \\
\hline const & -0.001 & 0.002 & 0.706 & 0.000 & 0.001 & 0.728 & -0.004 & 0.002 & 0.027 & * \\
\hline sd1 & -0.004 & 0.008 & 0.580 & 0.021 & 0.005 & $0.000 * * *$ & 0.016 & 0.008 & 0.053 & . \\
\hline $\mathrm{sd} 2$ & 0.004 & 0.009 & 0.649 & 0.013 & 0.006 & $0.026 *$ & 0.014 & 0.009 & 0.126 & \\
\hline $\mathrm{sd} 3$ & 0.018 & 0.008 & $0.034 *$ & 0.008 & 0.005 & 0.167 & 0.017 & 0.009 & 0.066 & . \\
\hline sd4 & 0.018 & 0.008 & $0.017 *$ & 0.012 & 0.005 & $0.023 *$ & 0.017 & 0.008 & 0.047 & * \\
\hline $\operatorname{sd} 5$ & 0.076 & 0.008 & $0.000 * * *$ & 0.019 & 0.005 & $0.001 * * *$ & 0.010 & 0.009 & 0.255 & \\
\hline sd6 & 0.095 & 0.011 & $0.000 * * *$ & 0.026 & 0.007 & $0.001 * * *$ & 0.021 & 0.012 & 0.082 & . \\
\hline $\operatorname{sd} 7$ & 0.051 & 0.014 & $0.001 * * *$ & 0.029 & 0.010 & $0.003 * *$ & 0.022 & 0.016 & 0.173 & \\
\hline $\operatorname{sd} 8$ & 0.040 & 0.015 & $0.009 * *$ & 0.037 & 0.010 & $0.000 * * *$ & 0.039 & 0.016 & 0.019 & $*$ \\
\hline sd9 & 0.003 & 0.013 & 0.794 & 0.034 & 0.008 & $0.000 * * *$ & 0.029 & 0.014 & 0.036 & * \\
\hline $\operatorname{sd} 10$ & -0.004 & 0.010 & 0.700 & 0.017 & 0.007 & $0.014 *$ & 0.019 & 0.011 & 0.076 & . \\
\hline $\operatorname{sd} 11$ & 0.007 & 0.009 & 0.408 & 0.002 & 0.006 & 0.766 & 0.014 & 0.009 & 0.135 & \\
\hline
\end{tabular}




\begin{tabular}{|c|c|c|c|c|}
\hline EU-quota & 0.004 & 0.833 & 0.944 & 0.006 \\
\hline Resid. st. error & 0.016 on $98 \mathrm{DF}$ & & 0.011 on $98 \mathrm{DF}$ & 0.018 on $98 \mathrm{DF}$ \\
\hline Mult. R-squ & 0.768 & & 0.682 & 0.142 \\
\hline Adj. R-squ & 0.719 & & 0.614 & -0.042 \\
\hline F-stat & 15.47 on 21 and $98 \mathrm{DF}$ & & 10.03 on 21 and $98 \mathrm{DF}$ & 0.769 on 21 and $98 \mathrm{DF}$ \\
\hline p-value & $<2.2 \mathrm{e}-16$ & & $2.98 \mathrm{E}-13$ & 0.749 \\
\hline
\end{tabular}

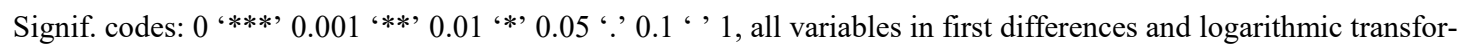
mation

$\mathrm{DF}=$ degrees of freedom, l=lagged, Quota.EU = end-of-EU-quota dummy: 0 before, 1 after 04/2015, sd=seasonal dummy

Table A7 (Butter): VAR in first differences with Swiss and German wholesale butter price and exchange rate

\begin{tabular}{|c|c|c|c|c|c|c|c|c|c|}
\hline \multirow[b]{3}{*}{ DE.11 } & \multicolumn{3}{|c|}{ CH Equation } & \multicolumn{3}{|c|}{ DE Equation } & \multicolumn{3}{|c|}{ Exchange Rate Equation } \\
\hline & \multirow{2}{*}{$\begin{array}{r}\text { Estimate } \\
0.017\end{array}$} & \multicolumn{2}{|c|}{ Std.Error $\operatorname{Pr}(>|t|)$} & \multirow{2}{*}{$\begin{array}{r}\text { Estimate } \\
0.471\end{array}$} & $\begin{array}{l}\text { Std.Er- } \\
\text { ror }\end{array}$ & $\operatorname{Pr}(>|t|)$ & Estimate & \multicolumn{2}{|c|}{ Std.Error $\operatorname{Pr}(>|t|)$} \\
\hline & & 0.020 & 0.390 & & 0.077 & $0.000 * * *$ & -0.001 & 0.025 & 0.978 \\
\hline CH.11 & -0.019 & 0.086 & 0.822 & -0.550 & 0.331 & 0.099 & 0.066 & 0.107 & 0.535 \\
\hline FX.11 & -0.066 & 0.068 & 0.336 & 0.052 & 0.262 & 0.842 & 0.096 & 0.084 & 0.260 \\
\hline const & 0.001 & 0.002 & 0.552 & 0.000 & 0.009 & 0.989 & 0.001 & 0.003 & 0.628 \\
\hline $\operatorname{sd} 1$ & -0.001 & 0.005 & 0.791 & 0.009 & 0.019 & 0.652 & 0.009 & 0.006 & 0.166 \\
\hline $\operatorname{sd} 2$ & -0.007 & 0.005 & 0.159 & 0.006 & 0.019 & 0.746 & 0.007 & 0.006 & 0.268 \\
\hline $\operatorname{sd} 3$ & -0.006 & 0.005 & 0.252 & 0.002 & 0.019 & 0.908 & 0.009 & 0.006 & 0.134 \\
\hline $\operatorname{sd} 4$ & -0.003 & 0.005 & 0.484 & 0.035 & 0.019 & 0.068 & 0.008 & 0.006 & 0.182 \\
\hline $\operatorname{sd} 5$ & -0.005 & 0.005 & 0.343 & 0.029 & 0.019 & 0.130 & 0.001 & 0.006 & 0.816 \\
\hline sd6 & 0.000 & 0.005 & 0.981 & 0.009 & 0.020 & 0.640 & 0.012 & 0.006 & 0.061 \\
\hline $\operatorname{sd} 7$ & -0.002 & 0.005 & 0.668 & 0.007 & 0.019 & 0.713 & 0.005 & 0.006 & 0.391 \\
\hline $\operatorname{sd} 8$ & -0.006 & 0.005 & 0.216 & 0.027 & 0.019 & 0.164 & 0.014 & 0.006 & $0.029 *$ \\
\hline $\operatorname{sd} 9$ & -0.001 & 0.005 & 0.909 & -0.007 & 0.019 & 0.715 & 0.012 & 0.006 & 0.058 \\
\hline $\operatorname{sd} 10$ & -0.003 & 0.005 & 0.521 & -0.007 & 0.019 & 0.722 & 0.005 & 0.006 & 0.424 \\
\hline $\operatorname{sd} 11$ & -0.003 & 0.005 & 0.489 & -0.008 & 0.019 & 0.676 & 0.009 & 0.006 & 0.160 \\
\hline Quota.EU & -0.001 & 0.004 & 0.856 & -0.005 & 0.016 & 0.767 & 0.005 & 0.005 & 0.322 \\
\hline Freetrade & 0.002 & 0.005 & 0.639 & -0.016 & 0.017 & 0.355 & -0.005 & 0.006 & 0.390 \\
\hline Resid. st. error & 0.013 on 1 & $139 \mathrm{DF}$ & & 0.048 on & $139 \mathrm{DF}$ & & 0.048 on 1 & $139 \mathrm{DF}$ & \\
\hline Mult. R-squ & 0.095 & & & 0.341 & & & 0.341 & & \\
\hline Adj. R-squ & -0.022 & & & 0.256 & & & 0.256 & & \\
\hline F-stat & 0.812 on 1 & 18 and 139 & & 3.993 on & 18 and 13 & $9 \mathrm{DF}$ & 3.993 on 1 & 18 and 139 & \\
\hline p-value & 0.683 & & & $1.35 \mathrm{E}-06$ & & & $1.35 \mathrm{E}-06$ & & \\
\hline
\end{tabular}

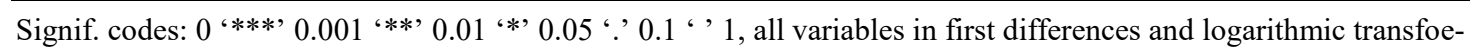
mation

$\mathrm{DF}=$ degrees of freedom, 1 =lagged, Freetrade $=$ cheese-free-trade-dummy: 0 before, 1 after 07/2007, Quota.EU = endof-EU-quota dummy: 0 before, 1 after 04/2015, sd = seasonal dummy 
Table A8 (Semi-hard cheese): VAR in first differences with Swiss semi-hard cheese and German Gouda-type wholesale price and exchange rate

\begin{tabular}{|c|c|c|c|c|c|c|c|c|c|}
\hline \multirow[b]{3}{*}{ DE.11 } & \multicolumn{3}{|c|}{ CH Equation } & \multicolumn{3}{|c|}{ DE Equation } & \multicolumn{3}{|c|}{ Exchange Rate Equation } \\
\hline & \multicolumn{3}{|c|}{ Estimate Std.Error $\operatorname{Pr}(>|t|)$} & \multicolumn{2}{|c|}{ Estimate Std.Error } & $\operatorname{Pr}(>|t|)$ & \multicolumn{3}{|c|}{ Estimate Std.Error $\operatorname{Pr}(>|t|)$} \\
\hline & 0.088 & 0.078 & 0.261 & 0.473 & 0.073 & $0.000 * * *$ & -0.010 & 0.038 & 0.793 \\
\hline CH.11 & -0.763 & 0.073 & $0.000 * * *$ & -0.122 & 0.068 & 0.074 . & -0.036 & 0.035 & 0.306 \\
\hline FX.11 & 0.552 & 0.154 & $0.000 * * *$ & 0.293 & 0.143 & $0.042 *$ & 0.131 & 0.074 & 0.079 . \\
\hline DE.12 & 0.038 & 0.087 & 0.666 & 0.022 & 0.081 & 0.786 & 0.040 & 0.042 & 0.338 \\
\hline CH.12 & -0.463 & 0.086 & $0.000 * * *$ & -0.153 & 0.080 & 0.057 . & 0.018 & 0.041 & 0.656 \\
\hline FX.12 & 0.113 & 0.158 & 0.476 & 0.071 & 0.147 & 0.629 & -0.073 & 0.076 & 0.341 \\
\hline DE.13 & 0.036 & 0.077 & 0.642 & -0.075 & 0.072 & 0.301 & -0.072 & 0.037 & 0.054 . \\
\hline CH.13 & -0.292 & 0.074 & $0.000 * * *$ & -0.213 & 0.069 & $0.002 * *$ & -0.030 & 0.036 & 0.407 \\
\hline FX.13 & 0.296 & 0.157 & 0.062 . & -0.024 & 0.146 & 0.869 & 0.044 & 0.076 & 0.560 \\
\hline const & 0.000 & 0.005 & 0.958 & 0.004 & 0.005 & 0.447 & 0.000 & 0.003 & 0.854 \\
\hline $\mathrm{sd} 1$ & -0.001 & 0.011 & 0.941 & -0.003 & 0.010 & 0.800 & 0.006 & 0.005 & 0.224 \\
\hline $\mathrm{sd} 2$ & 0.008 & 0.011 & 0.471 & -0.005 & 0.011 & 0.668 & 0.004 & 0.005 & 0.479 \\
\hline $\mathrm{sd} 3$ & 0.008 & 0.011 & 0.480 & -0.011 & 0.010 & 0.300 & 0.006 & 0.005 & 0.223 \\
\hline sd4 & 0.018 & 0.010 & 0.088 . & 0.003 & 0.010 & 0.749 & 0.003 & 0.005 & 0.528 \\
\hline sd5 & 0.019 & 0.010 & 0.064 . & 0.007 & 0.010 & 0.485 & 0.001 & 0.005 & 0.799 \\
\hline sd6 & 0.010 & 0.010 & 0.319 & 0.021 & 0.010 & $0.030 *$ & 0.006 & 0.005 & 0.246 \\
\hline $\operatorname{sd} 7$ & 0.005 & 0.010 & 0.609 & 0.000 & 0.010 & 0.981 & 0.002 & 0.005 & 0.670 \\
\hline $\operatorname{sd} 8$ & 0.034 & 0.011 & $0.002 * *$ & 0.003 & 0.010 & 0.768 & 0.008 & 0.005 & 0.114 \\
\hline sd9 & 0.034 & 0.010 & $0.001 * *$ & 0.010 & 0.010 & 0.329 & 0.008 & 0.005 & 0.130 \\
\hline sd10 & 0.056 & 0.010 & $0.000 * * *$ & 0.005 & 0.009 & 0.581 & 0.004 & 0.005 & 0.426 \\
\hline sd11 & 0.045 & 0.010 & $0.000 * * *$ & 0.016 & 0.010 & 0.094 . & 0.006 & 0.005 & 0.224 \\
\hline Quota.EU & -0.003 & 0.008 & 0.735 & 0.004 & 0.008 & 0.655 & 0.006 & 0.004 & 0.175 \\
\hline Freetrade & -0.002 & 0.010 & 0.821 & 0.011 & 0.009 & 0.251 & -0.005 & 0.005 & 0.273 \\
\hline $\begin{array}{l}\text { Resid. st. } \\
\text { error }\end{array}$ & \multicolumn{3}{|c|}{0.029 on $179 \mathrm{DF}$} & \multicolumn{3}{|c|}{0.027 on $179 \mathrm{DF}$} & \multicolumn{3}{|c|}{0.014 on $179 \mathrm{DF}$} \\
\hline $\begin{array}{l}\text { Mult. R- } \\
\text { squ }\end{array}$ & \multicolumn{3}{|l|}{0.480} & \multicolumn{3}{|l|}{0.378} & \multicolumn{3}{|l|}{0.128} \\
\hline Adj. R-squ & \multicolumn{3}{|l|}{ u 0.410} & \multicolumn{3}{|l|}{0.295} & \multicolumn{3}{|l|}{0.011} \\
\hline F-stat & \multicolumn{3}{|c|}{6.88 on 24 and $179 \mathrm{DF}$} & \multicolumn{3}{|c|}{4.535 on 24 and $179 \mathrm{DF}$} & \multicolumn{3}{|c|}{1.097 on 24 and $179 \mathrm{DF}$} \\
\hline p-value & \multicolumn{3}{|l|}{$2.11 \mathrm{E}-12$} & \multicolumn{3}{|l|}{$1.445 \mathrm{E}-09$} & \multicolumn{3}{|l|}{0.351} \\
\hline
\end{tabular}

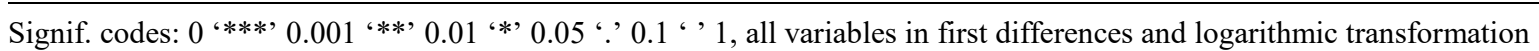
$\mathrm{DF}=$ degrees of freedom, 1 =lagged, Freetrade = cheese-free-trade-dummy: 0 before, 1 after 07/2007, Quota.EU = end-ofEU-quota dummy: 0 before, 1 after 04/2015, sd = seasonal dummy

Table A9 (Hard cheese): VAR in first differences with Swiss hard cheese and German Emmental-type wholesale price and exchange rate

\begin{tabular}{|c|c|c|c|c|c|c|c|c|c|c|c|}
\hline & \multicolumn{4}{|c|}{ CH Equation } & \multicolumn{4}{|c|}{ DE Equation } & \multicolumn{3}{|c|}{ Exchange Rate Equation } \\
\hline & Estimate & Std.Error & $\operatorname{Pr}(>|t|)$ & & Estimate & $\begin{array}{l}\text { Std.Er- } \\
\text { ror }\end{array}$ & $\operatorname{Pr}(>|t|)$ & & Estimate & Std.Error & $\operatorname{Pr}(>|t|)$ \\
\hline DE.11 & 0.221 & 0.115 & 0.057 & & 0.343 & 0.074 & 0.000 & $* * *$ & -0.014 & 0.057 & 0.057 \\
\hline CH.11 & -0.397 & 0.072 & 0.000 & $* * *$ & 0.016 & 0.047 & 0.734 & & -0.038 & 0.036 & $0.000 * * *$ \\
\hline
\end{tabular}




\begin{tabular}{|c|c|c|c|c|c|c|c|c|c|c|c|c|}
\hline FX.11 & 0.238 & 0.150 & 0.114 & & -0.047 & 0.097 & 0.625 & & 0.107 & 0.075 & 0.114 & \\
\hline DE.12 & -0.025 & 0.116 & 0.830 & & 0.078 & 0.075 & 0.302 & & 0.024 & 0.058 & 0.830 & \\
\hline CH.12 & -0.294 & 0.071 & 0.000 & $* * *$ & 0.036 & 0.046 & 0.436 & & -0.056 & 0.035 & 0.000 & $* * *$ \\
\hline FX.12 & 0.089 & 0.151 & 0.557 & & -0.057 & 0.097 & 0.561 & & -0.032 & 0.075 & 0.557 & \\
\hline const & -0.003 & 0.005 & 0.585 & & 0.001 & 0.003 & 0.760 & & -0.001 & 0.003 & 0.585 & \\
\hline sd1 & 0.006 & 0.010 & 0.538 & & 0.016 & 0.007 & 0.015 & $*$ & 0.006 & 0.005 & 0.538 & \\
\hline $\mathrm{sd} 2$ & 0.011 & 0.010 & 0.280 & & 0.011 & 0.006 & 0.088 & . & 0.004 & 0.005 & 0.280 & \\
\hline $\mathrm{sd} 3$ & -0.002 & 0.010 & 0.814 & & 0.013 & 0.006 & 0.048 & $*$ & 0.006 & 0.005 & 0.814 & \\
\hline $\mathrm{sd} 4$ & 0.003 & 0.010 & 0.768 & & 0.011 & 0.006 & 0.094 & . & 0.005 & 0.005 & 0.768 & \\
\hline $\operatorname{sd} 5$ & 0.003 & 0.010 & 0.730 & & 0.007 & 0.006 & 0.304 & & 0.001 & 0.005 & 0.730 & \\
\hline sd6 & 0.029 & 0.010 & 0.004 & $* *$ & 0.018 & 0.006 & 0.006 & $* *$ & 0.007 & 0.005 & 0.004 & $* *$ \\
\hline $\mathrm{sd} 7$ & 0.018 & 0.010 & 0.071 & . & 0.015 & 0.007 & 0.026 & $*$ & 0.004 & 0.005 & 0.071 & . \\
\hline $\operatorname{sd} 8$ & 0.028 & 0.010 & 0.005 & $* *$ & 0.017 & 0.006 & 0.011 & $*$ & 0.010 & 0.005 & 0.005 & $* *$ \\
\hline sd9 & 0.049 & 0.010 & 0.000 & $* * *$ & 0.021 & 0.006 & 0.002 & $* *$ & 0.007 & 0.005 & 0.000 & $* * *$ \\
\hline sd10 & 0.026 & 0.011 & 0.015 & $*$ & 0.008 & 0.007 & 0.221 & & 0.006 & 0.005 & 0.015 & $*$ \\
\hline sd11 & 0.009 & 0.010 & 0.377 & & 0.016 & 0.007 & 0.016 & $*$ & 0.007 & 0.005 & 0.377 & \\
\hline Quota.EU & -0.008 & 0.008 & 0.334 & & 0.000 & 0.005 & 0.942 & & 0.004 & 0.004 & 0.334 & \\
\hline Freetrade & -0.010 & 0.010 & 0.298 & & -0.001 & 0.006 & 0.872 & & -0.007 & 0.005 & 0.298 & \\
\hline $\begin{array}{l}\text { Resid. st. er- } \\
\text { ror }\end{array}$ & \multicolumn{4}{|c|}{0.029 on $183 \mathrm{DF}$} & \multicolumn{4}{|c|}{0.019 on $183 \mathrm{DF}$} & \multicolumn{4}{|c|}{0.014 on $183 \mathrm{DF}$} \\
\hline Mult. R-squ & \multicolumn{4}{|l|}{0.321} & \multicolumn{4}{|l|}{0.223} & \multicolumn{4}{|l|}{0.093} \\
\hline Adj. R-squ & \multicolumn{4}{|l|}{0.243} & \multicolumn{4}{|l|}{0.133} & \multicolumn{4}{|l|}{-0.011} \\
\hline F-stat & \multicolumn{4}{|c|}{4.126 on 21 and $183 \mathrm{DF}$} & \multicolumn{4}{|c|}{1.495 on 21 and $183 \mathrm{DF}$} & \multicolumn{4}{|c|}{0.894 on 21 and $183 \mathrm{DF}$} \\
\hline p-value & \multicolumn{4}{|l|}{$6.67 \mathrm{E}-08$} & \multicolumn{4}{|l|}{0.001} & \multicolumn{4}{|l|}{0.599} \\
\hline
\end{tabular}

Signif. codes: 0 “*** 0.001 '**' 0.01 '*’ 0.05 '? 0.1 ' ' 1 , all variables in first differences and logarithmic transformation $\mathrm{DF}=$ degrees of freedom, 1 =lagged, Freetrade = cheese-free-trade-dummy: 0 before, 1 after 07/2007, Quota.EU = end-ofEU-quota dummy: 0 before, 1 after 04/2015, sd = seasonal dummy 


\title{
III Vertical Price Transmission in Swiss Dairy and Cheese Value Chains
}

Author: Judith Hillen

\begin{abstract}
In Switzerland, there are separated value chains for dairy and cheese products, which differ in terms of industry concentration, value chain governance, and product characteristics. We analyze how milk prices are passed on along these different value chains. Using detailed price data on farm-gate, wholesale, export, and retail levels, we apply asymmetric Vector Autoregressive and Vector Error Correction Models to study vertical price transmission in Swiss dairy and cheese chains. Contrary to most existing literature, we find almost no long-run price relationships and no significant asymmetries between the different stages and products and discuss the potential reasons.
\end{abstract}

KEYWORDS: price transmission, value chains, Switzerland, milk prices 


\section{Introduction}

Vertical price transmission in milk markets has received considerable research attention in the past decades, as prices are a main link between different market levels and are an important factor for agricultural efficiency (Serra and Goodwin 2003). Also, in Switzerland, there is a long-lasting and vivid public debate about milk prices, especially at the producer level, with strong opinions about "fair" or "unfair" milk prices (e.g., Cornall 2017). Lately, Swiss dairy market organizations and agricultural consultants have given some attention to how more value can be retained by producers (SBV 2013, Reviron et al. 2017). Yet, the relationships between prices at different stages of the dairy and cheese value chains have not yet been analyzed systematically and quantified. Therefore, this study analyzes vertical price transmission in the Swiss milk market.

For other countries, numerous studies have examined the price relationships in different milk and dairy markets. Table 1 provides an overview of existing studies dealing with vertical milk price transmission. ${ }^{5}$ More than $60 \%$ of these 21 studies focus exclusively on farm-gate and retail prices; the remaining also include wholesale or processor levels, but only two studies include the three stages (farm-gate, processing/wholesale, and retail) (Jaffry and Grigoryev 2011, Kharin et al. 2017). While the specific focus differs among these studies, the majority finds long-run price transmission elasticities with positive asymmetries in the long- and/or short-run. This implies that price increases are passed on at a greater magnitude/speed than price decreases. Only one study finds no vertical long-run relationship (Kharin 2015); this is for Russian farm and retail milk prices. Also, the findings regarding the direction of price transmission are consistent across most case studies, which find that prices are passed on downstream, that is, either from producer or wholesale to retail prices. This is in line with the concept of mark-up pricing (Tirole 1988). Only Bakucz et al. (2012) find that in Poland, retail price changes cause farm-gate price changes.

Despite the large number of case studies available, we want to add another one for Switzerland for the following reasons. First, highly detailed price data are available. We are able to include four value chain levels: farm-gate, wholesale, export, and retail prices. These data are available for a large number of products, including cheese, dairy, and organic products at the retail level and corresponding producer prices, separated by processing use, at the farm-gate level. Hence, we are able to analyze and compare price transmission along different value chains in the dairy,

\footnotetext{
5 Studies analyzing multiple products are not included, nor are unpublished studies with unclear results or low
} numbers of observations and studies published before the year 2000 . 
cheese, and organic sector. A second reason is that in Switzerland, those chains are strictly separated and differ in terms of industry concentration, value chain governance, and product characteristics. This allows us to derive insights on the reasons for different magnitude, speed, and (a)symmetry of price transmission.

Table 1: Literature review of existing vertical milk price transmission studies

\begin{tabular}{|c|c|c|c|c|c|c|c|c|}
\hline Authors & Time period & Method & Region & Level & Products & Frequ. & Coint. & Asymm. \\
\hline $\begin{array}{l}\text { Acosta \& Valdes } \\
(2013)\end{array}$ & 1991-2011 & Asymm. ECM & Panama & $\mathrm{F}, \mathrm{W}$ & milk & $\begin{array}{l}\text { mon- } \\
\text { thly }\end{array}$ & yes & pos. \\
\hline $\begin{array}{l}\text { Antonioli \& Santer- } \\
\text { amo (2017) }\end{array}$ & $2000-2016$ & Asymm. ECM & Italy & Pr, R & milk & $\begin{array}{l}\text { mon- } \\
\text { thly }\end{array}$ & yes & pos. \\
\hline $\begin{array}{l}\text { Bakucs \& Ferto } \\
(2008)\end{array}$ & $1992-2007$ & $\begin{array}{l}\text { Gregory-Hansen } \\
\text { cointegration }\end{array}$ & Hungary & $\mathrm{F}, \mathrm{R}$ & milk & $\begin{array}{l}\text { mon- } \\
\text { thly }\end{array}$ & yes & pos. \\
\hline $\begin{array}{l}\text { Bakucs, Fałkowski \& } \\
\text { Fertő (2012) }\end{array}$ & $1995-2007$ & Asymm. VECM & $\begin{array}{l}\text { Poland and } \\
\text { Hungary }\end{array}$ & $\mathrm{F}, \mathrm{R}$ & milk & $\begin{array}{l}\text { mon- } \\
\text { thly }\end{array}$ & yes & partly \\
\hline $\begin{array}{l}\text { Bittmann, Holzer \& } \\
\text { Loy (2017) }\end{array}$ & $2005-2011$ & $\begin{array}{l}\text { panel four-regime } \\
\text { ECM }\end{array}$ & Germany & $\mathrm{W}, \mathrm{R}$ & milk & weekly & yes & $\mathrm{n} / \mathrm{a}$ \\
\hline $\begin{array}{l}\text { Bolotova \& Novako- } \\
\text { vic (2012) }\end{array}$ & 1991-2008 & $\begin{array}{l}\text { MUM (Houck } \\
\text { 1977, Heien 1980) }\end{array}$ & $\begin{array}{l}5 \text { New York } \\
\text { State cities }\end{array}$ & $\mathrm{F}, \mathrm{R}$ & milk & $\begin{array}{l}\text { mon- } \\
\text { thly }\end{array}$ & yes & pos. \\
\hline $\begin{array}{l}\text { Bor, Ismihan \& Baya- } \\
\text { ner (2014) }\end{array}$ & $2003-2012$ & Asymm. ECM & Turkey & $\mathrm{F}, \mathrm{R}$ & milk & $\begin{array}{l}\text { mon- } \\
\text { thly }\end{array}$ & yes & pos. \\
\hline $\begin{array}{l}\text { Capps \& Sherwell } \\
(2007)\end{array}$ & 1994-2002 & Asymm. ECM & $\begin{array}{l}\text { Seven US ci- } \\
\text { ties }\end{array}$ & $\mathrm{F}, \mathrm{R}$ & milk & $\begin{array}{l}\text { mon- } \\
\text { thly }\end{array}$ & yes & pos. \\
\hline $\begin{array}{l}\text { Chavas \& Mehta } \\
\text { (2004) }\end{array}$ & $1980-2001$ & Asymm. ECM & USA & $\mathrm{W}, \mathrm{R}$ & butter & $\begin{array}{l}\text { mon- } \\
\text { thly }\end{array}$ & yes & pos. \\
\hline $\begin{array}{l}\text { De Oliveira, Car- } \\
\text { valho, Lucas \& Peixe } \\
(2015)\end{array}$ & 2001-2011 & $\begin{array}{l}\text { VECM/VAR in } \\
\text { first differences }\end{array}$ & $\begin{array}{l}\text { Portugal } \\
\text { mainland and } \\
\text { Azores }\end{array}$ & $\begin{array}{l}\text { Feed, F, } \\
\mathrm{R}\end{array}$ & milk & $\begin{array}{l}\text { mon- } \\
\text { thly }\end{array}$ & partly & $\mathrm{n} / \mathrm{a}$ \\
\hline Falkowski (2010) & $1995-2006$ & Asymm. VECM & Poland & $\mathrm{F}, \mathrm{R}$ & milk & $\begin{array}{l}\text { mon- } \\
\text { thly }\end{array}$ & yes & pos. \\
\hline $\begin{array}{l}\text { Fernández-Amador, } \\
\text { Baumgartner \& Cre- } \\
\text { spo Cuaresma (2010) }\end{array}$ & $1996-2010$ & TVECM & Austria & $\mathrm{F}, \mathrm{R}$ & $\begin{array}{l}\text { milk, but- } \\
\text { ter, } \\
\text { cheese }\end{array}$ & $\begin{array}{l}\text { mon- } \\
\text { thly }\end{array}$ & yes & pos. \\
\hline $\begin{array}{l}\text { Jaffry \& Grigoryev } \\
\text { (2011) }\end{array}$ & $1989 *-2010$ & Asymm. ECM & $\begin{array}{l}\text { United King- } \\
\text { dom }\end{array}$ & $\mathrm{F}, \mathrm{W}, \mathrm{R}$ & $\begin{array}{l}\text { milk, } \\
\text { cheddar }\end{array}$ & $\begin{array}{l}\text { mon- } \\
\text { thly }\end{array}$ & yes & partly \\
\hline Kharin (2015) & $2002-2014$ & $\mathrm{ADL}$ & Russia & $\mathrm{F}, \mathrm{R}$ & milk & $\begin{array}{l}\text { mon- } \\
\text { thly }\end{array}$ & no & $\mathrm{n} / \mathrm{a}$ \\
\hline $\begin{array}{l}\text { Kharin, Lajdova \& } \\
\text { Bielik (2017) }\end{array}$ & $2010-2016$ & VECM & $\begin{array}{l}\text { Slovak Re- } \\
\text { public }\end{array}$ & $\mathrm{F}, \operatorname{Pr}, \mathrm{R}$ & milk & $\begin{array}{l}\text { mon- } \\
\text { thly }\end{array}$ & yes & partly \\
\hline Lass (2005) & $1982-2001$ & $\begin{array}{l}\text { MUM (Kinnucan \& } \\
\text { Forker 1987) }\end{array}$ & $\begin{array}{l}\text { Boston, MA; } \\
\text { Hartford, CT }\end{array}$ & $\mathrm{F}, \mathrm{R}$ & milk & $\begin{array}{l}\text { mon- } \\
\text { thly }\end{array}$ & yes & pos. \\
\hline $\begin{array}{l}\text { Liu, Rabinowitz \& } \\
\text { Xuan (2017) }\end{array}$ & $2006-2011$ & Asymm. VECM & USA & $\mathrm{F}, \mathrm{R}$ & milk & $\begin{array}{l}\text { mon- } \\
\text { thly }\end{array}$ & yes & pos. \\
\hline $\begin{array}{l}\text { Loy, Holm, Steinha- } \\
\text { gen \& Glauben } \\
(2015)\end{array}$ & $2005-2008$ & panel TVECM & Germany & $\mathrm{W}, \mathrm{R}$ & $\begin{array}{l}\text { milk, but- } \\
\text { ter }\end{array}$ & weekly & yes & pos. \\
\hline $\begin{array}{l}\text { Serra \& Goodwin } \\
(2003)\end{array}$ & $1994-2000$ & Asymm. TVECM & Spain & $\mathrm{F}, \mathrm{R}$ & $\begin{array}{l}14 \text { pro- } \\
\text { ducts }\end{array}$ & weekly & yes & pos. \\
\hline
\end{tabular}




\begin{tabular}{|c|c|c|c|c|c|c|c|c|}
\hline $\begin{array}{l}\text { Stewart \& Blayney } \\
\text { (2011) }\end{array}$ & $2000-2010$ & $\begin{array}{l}\text { Linear, threshold, } \\
\text { and cubic polyno- } \\
\text { mial ECM }\end{array}$ & USA & $\mathrm{F}, \mathrm{R}$ & $\begin{array}{l}\text { milk, } \\
\text { cheddar }\end{array}$ & $\begin{array}{l}\text { mon- } \\
\text { thly }\end{array}$ & yes & pos. \\
\hline Zeng \& Gould (2016) & $2001-2011$ & Asymm. ECM & 16 US cities & $\mathrm{F}, \mathrm{R}$ & milk & $\begin{array}{l}\text { mon- } \\
\text { thly }\end{array}$ & yes & partly \\
\hline
\end{tabular}

$\mathrm{ADL}=$ autoregressive distributed lags model, $\mathrm{MUM}=$ Mark-Up Model, $(\mathrm{T})(\mathrm{V}) \mathrm{ECM}=($ Threshold $)($ Vector $)$ Error Correction Model, VAR = Vector autoregressive, $\mathrm{F}=$ Farmgate, $\mathrm{Pr}=$ Processor, $\mathrm{R}=$ Retail, $\mathrm{W}=$ Wholesale, $\mathrm{n} / \mathrm{a}$ : not tested

* Varying starting points from 1989 -2007, depending on availability. For a more detailed overview on US milk price transmission studies, see US Government Accountability Office (2004), pp. 136 - 149.

\section{Framework}

The milk sector is of key importance for Swiss agriculture, representing about $25 \%$ of the national agricultural production value (SBV 2013). As about $44 \%$ of all Swiss farms engage in milk production, the milk price is highly relevant for farm income (SBV 2013).

\subsection{Structure of the Swiss milk market}

In Switzerland, the processing channels for cheese and other dairy products are strictly separated; about $43 \%$ of Swiss raw milk is processed into cheese, and the remaining $57 \%$ is processed into other, non-cheese dairy products (SMP 2019).

The farm level is characterized by many small-scale farmers, even though some structural change with decreasing numbers of dairy farms and increasing farm sizes has occurred in the past decades. In 2017, dairy farms had on average 25 cows and produced 158 tons of milk per year (TSM et al. 2017). Yet, there is large heterogeneity on the farm level; farms that supply raw milk to artisanal cheese dairies, especially those under protected designation of origin $(36 \%$ of all dairy farmers), must fulfill certain specifications regarding production region and feeding, for example, not feeding dairy cows silage fodder. Farms that supply milk to industrial dairies produce rather homogeneous raw milk without such restrictions (Flury et al. 2014). Therefore, producer prices depend on the processing used and are generally higher for milk processed into cheese, partly thanks to a targeted subsidy payment for cheese processing. ${ }^{6}$

The structure, concentration, and governance of the milk processing industry also differs between the "artisanal" cheese and the "industrial" dairy processing systems. In the artisanal cheese production of matured hard- and semi-hard cheese, only raw milk from silage-free production is used. There are several hundred regional and artisanal cheese dairies of varying sizes.

\footnotetext{
6 The Swiss payment for milk processed into cheese was introduced in 1999 to help farmers and processors dealing with the liberalization of the cheese market with the European Union, enhancing competitiveness with EU producers and stabilizing income. The Swiss government pays this subsidy (initially $0.20 \mathrm{CHF}$, currently $0.15 \mathrm{CHF}$ per liter) to the cheese dairies who are supposed to pass it on to the milk producers. As the Swiss dairy market, that is, all non-cheese milk products, are still protected by tariffs and tariff rate quotas, this payment is meant to offset this difference in border protection (for details, see Finger et al. 2017).
} 
These dairies usually belong to the local producer association, or at least there is a close link between producers, dairies, and maturing companies, as they are jointly organized in brand associations (Reviron et al. 2004). Among those artisanal cheese types, 12 are under the protected designation of origin (AOP, Appellation d'Origine Protegée), and therefore restricted to specific geographic regions. Emmentaler and Gruyère are the most well-known and most produced AOP cheese varieties (TSM et al. 2017). Artisanal processors depend on a reliable supply of raw milk that fulfills the specific regional and quality criteria. Therefore, they need to provide producers with sufficient incentives to stay in milk production and to make the specific investments necessary to deliver the required quality. In contrast, the dairy processing industry is dominated by a few large companies that are supplied by "generic" raw milk producers, who only need to fulfil national quality standards. They produce all kinds of standardized (e.g., butter, milk powder) and speciality dairy products (e.g., deserts, ice cream) and some industrial cheese types made from pasteurized milk, such as mozzarella and cream cheese (Haller 2014). Producers deliver their milk either to a producer association or directly to one of the dairies. Either way, after selling to this first milk buyer, producers cannot trace how their milk is processed and marketed.

At the retail stage, concentration is very high, often described as a duopoly, because two retailers (Coop and Migros) account for more than 70\% of the market share (EDA 2017). Migros has its own dairy processor (Elsa), while Coop is mainly supplied by Emmi, Switzerland's largest dairy company. In the mid-2000s, two discounters (Aldi and Lidl) entered the Swiss market, but in 2016 , they jointly reached only $2.8 \%$ of the overall retail market share, and $8.3 \%$ of the food retail market share (EDA 2017).

\subsection{Potential influence on vertical price transmission}

The different characteristics of the Swiss dairy and cheese processing chains could have an influence on price transmission along the value chains. Our hypothesis is that there is high and symmetric price transmission in artisanal cheese processing, and low and asymmetric price transmission in industrial dairy processing chains.

In the artisanal cheese chain, one would expect high price transmission because of the high price transparency between different stages; most cheese dairies produce one or few specific types of cheese. Hence, producers or cheese processors can trace down the price at which their products are sold at downstream stages and can detect increased margins. The predominant cheese value chain governance structures are hybrid forms classified as "relational networks" and "leadership" (Reviron et al. 2017), with close coordination between the different sellers 
and buyers. This allows for intensive producer participation in downstream decision-making processes, for instance, regarding marketing channels or quantity control, and hence implicitly, pricing decisions. However, in contrast to spot markets, where prices coordinate supply and demand, in these hybrid governance forms, there are longer-term relational contracts between buyer and seller (Ménard 2004 and 2018). Such contractually fixed prices, or price spans, may prohibit an immediate pass-through of changing costs or prices. Finally, the cheese value chain is characterized by many small cheese dairies and low firm concentration. However, this relationship between concentration, market power, and price transmission behavior is not yet fully understood. Whereas some early literature argued that high industry concentration caused imperfect, asymmetric price transmission (Kinnucan and Forker 1987), this direct relationship has been questioned theoretically (McCorriston et al. 2001, Weldegebriel 2004) and empirically (Peltzman 2000, Aguiar and Santana 2002).

In the industrial dairy processing chain, one would expect imperfect (i.e., low and asymmetric) price transmission because of the following characteristics. There is almost no price transparency along the value chain. Especially for dairy farmers, traceability stops at first milk purchaser, that is, either to a producer organization or directly to an industrial dairy. Loose governance forms (classified as "Trust" according to Reviron et al. 2017) foster this problem of asymmetric information. Producers are not involved in any downstream activities and therefore do not know how their milk will be processed and sold further, and at what price. The milk they deliver could be processed into cheap milk powder for world market export or into premium ice cream. The high concentration at the processor level presumably allows for the execution of market power, but again, the direction and strength of the effect on price transmission is not so clear, and empirical evidence is mixed (e.g., Cutts and Kirsten 2006, Loy et al. 2018).

\section{Data and Methods}

\subsection{Data}

We used monthly Swiss prices from January 2004 until March 2018, collected at farm-gate (F), wholesale (W), export (E), and retail (R) levels, as far as available (Table 2). 
Table 2: Data description of all used Swiss dairy and cheese prices

\begin{tabular}{|c|c|c|c|c|c|c|}
\hline Variable & Description & Measure & Time period & Source & Mean & Sd \\
\hline \multicolumn{7}{|c|}{ Farm-gate producer price } \\
\hline P_dai & For production of any non-cheese products & $\mathrm{Rp} . / \mathrm{kg}$ & $1 / 2004-3 / 2018$ & FOAG & 64.10 & 7.30 \\
\hline P_che_art & For artisan cheese production, silage-free feeding & $\mathrm{Rp} . / \mathrm{kg}$ & $1 / 2004-3 / 2018$ & FOAG & 73.29 & 2.82 \\
\hline P_emm & For Emmentaler AOP cheese production & $\mathrm{Rp} . / \mathrm{kg}$ & $1 / 2004-3 / 2018$ & FOAG & 66.91 & 5.03 \\
\hline P_gru & For Gruyère AOP cheese production & $\mathrm{Rp} . / \mathrm{kg}$ & $1 / 2004-3 / 2018$ & FOAG & 80.75 & 2.32 \\
\hline P_che_ind & For cheese production by industrial dairies ${ }^{7}$ & $\mathrm{Rp} . / \mathrm{kg}$ & $1 / 2004-3 / 2018$ & FOAG & 65.39 & 6.87 \\
\hline P_org & $\begin{array}{l}\text { Organic raw milk for any processing channel, } \\
\text { standards defined by Bio Suisse }(2015)\end{array}$ & $\mathrm{Rp} . / \mathrm{kg}$ & $1 / 2004-3 / 2018$ & FOAG & 79.72 & 4.80 \\
\hline \multicolumn{7}{|l|}{ Export price* } \\
\hline E_hard & all hard cheese. TL 0406.9099 & $\mathrm{CHF} / \mathrm{kg}$ & $1 / 2004-3 / 2018$ & FCA & 9.66 & 0.69 \\
\hline E_semi & all semi-hard cheese. TL 0406.9091 & $\mathrm{CHF} / \mathrm{kg}$ & $1 / 2004-3 / 2018$ & FCA & 10.74 & 1.55 \\
\hline E_emm & Emmentaler cheese (AOP) & $\mathrm{CHF} / \mathrm{kg}$ & $1 / 2004-5 / 2017$ & FCA & 8.59 & 0.83 \\
\hline E_gru & Gruyère cheese (AOP) & $\mathrm{CHF} / \mathrm{kg}$ & $1 / 2004-5 / 2017$ & FCA & 12.81 & 0.74 \\
\hline E_melt & Melted cheese, not grated or powder, TL 0406.30 & $\mathrm{CHF} / \mathrm{kg}$ & $1 / 2004-3 / 2018$ & FCA & 7.50 & 0.68 \\
\hline \multicolumn{7}{|l|}{ Wholesale price } \\
\hline W_but & Butter, salted or unsalted & $\mathrm{CHF} / \mathrm{kg}$ & $1 / 2004-3 / 2018$ & FOAG & 10.08 & 0.70 \\
\hline W_wmp & Whole milk powder, $26 \%$ fat, for food preparation & $\mathrm{CHF} / \mathrm{kg}$ & $1 / 2004-3 / 2018$ & FOAG & 6.33 & 0.34 \\
\hline W_smp & Skimmed milk powder, $<1.5 \%$ fat, for food preparation & $\mathrm{CHF} / \mathrm{kg}$ & $1 / 2004-3 / 2018$ & FOAG & 4.44 & 0.42 \\
\hline \multicolumn{7}{|l|}{ Retail price } \\
\hline R_milk & Pasteurized whole milk & $\mathrm{CHF} / 1$ & $1 / 2004-3 / 2018$ & FOAG & 1.46 & 0.06 \\
\hline R_but & Butter for cooking («Die Butter») & $\mathrm{CHF} / 250 \mathrm{~g}$ & $1 / 2004-3 / 2018$ & FOAG & 2.98 & 0.15 \\
\hline R_emm & Emmentaler surchoix & $\mathrm{CHF} / \mathrm{kg}$ & $1 / 2004-3 / 2018$ & FOAG & 19.03 & 0.90 \\
\hline R_gru & Gruyère surchoix & $\mathrm{CHF} / \mathrm{kg}$ & $1 / 2004-3 / 2018$ & FOAG & 19.89 & 0.72 \\
\hline R_app & Appenzeller surchoix & $\mathrm{CHF} / \mathrm{kg}$ & $1 / 2004-3 / 2018$ & FOAG & 18.96 & 0.93 \\
\hline R_mozz & Mozzarella & $\mathrm{CHF} / 150 \mathrm{~g}$ & $1 / 2004-3 / 2018$ & FOAG & 1.74 & 0.27 \\
\hline $\mathrm{R} \_$racl & Raclette (block) & $\mathrm{CHF} / \mathrm{kg}$ & $1 / 2004-3 / 2018$ & FOAG & 19.59 & 1.21 \\
\hline R_milk_org & Organic pasteurized whole milk & $\mathrm{CHF} / 1$ & $1 / 2006-3 / 2018$ & FOAG & 1.77 & 0.04 \\
\hline R_but_org & Organic butter («Vorzugsbutter») & $\mathrm{CHF} / 200 \mathrm{~g}$ & $1 / 2006-3 / 2018$ & FOAG & 3.84 & 0.12 \\
\hline R_emm_org & Organic Emmentaler & $\mathrm{CHF} / \mathrm{kg}$ & $1 / 2006-3 / 2018$ & FOAG & 20.20 & 1.03 \\
\hline R_gru_org & Organic Gruyère & $\mathrm{CHF} / \mathrm{kg}$ & $1 / 2006-3 / 2018$ & FOAG & 21.01 & 0.71 \\
\hline R_mozz_org & Organic Mozzarella & $\mathrm{CHF} / 150 \mathrm{~g}$ & $1 / 2006-3 / 2018$ & FOAG & 2.27 & 0.17 \\
\hline
\end{tabular}

$\mathrm{AOP}=$ protected designation of origin (Appellation d'Origine Protegée), $\mathrm{CHF}=$ Swiss Francs, FCA = Swiss Federal Customs Administration, $\mathrm{FOAG}=$ Swiss Federal Office for Agriculture, $\mathrm{Rp} .=$ Rappen $(0.01 \mathrm{CHF}), \mathrm{TL}=$ tariff line

* Export prices for dairy products (e.g., fluid milk, butter, milk powder) are available, but excluded from the analysis due to high product heterogeneity and very low trading volumes leading to highly volatile export unit values.

\footnotetext{
Industrial cheese includes all non-artisanal cheese production by large dairies, such as Mozzarella and numerous semi-hard, fresh and soft cheese types that can be made from pasteurized milk. In contrast to raw milk for artisan cheese production, raw milk for industrial cheese production is not subject to strict specifications: The use of silage fodder is allowed und there are no geographic origin restrictions. In fact, the requirements are the same as for the production of other dairy products. Hence, this producer price is closely related with the producer price for dairy milk: The farmers deliver their milk to one of the large dairies (either directly or via an intermediary first milk buyer), where it is pooled and processed into various dairy products, including industrially processed cheese. These large dairies (or other first milk buyers, such as producer organizations) report how much milk was processed into cheese. This is well-documented, because with some minor exceptions (small amounts of low fat cheese), the processors receive the cheese processing aid for these quantities.
} 
All farm-gate producer prices represent monthly weighted averages of the prices received by the farmers for raw milk. To ensure comparability across different producer prices, prices include only the processing aid for cheese and no other duties or bonuses such as the subsidy for silage-free production. We included six different producer prices. Figure 1 shows how the included prices are related, and how they can be grouped into different value chains. Those prices connected by an arrow are jointly analyzed regarding price transmission. Figures A1-A5 in the appendix illustrate the nominal price development over time.

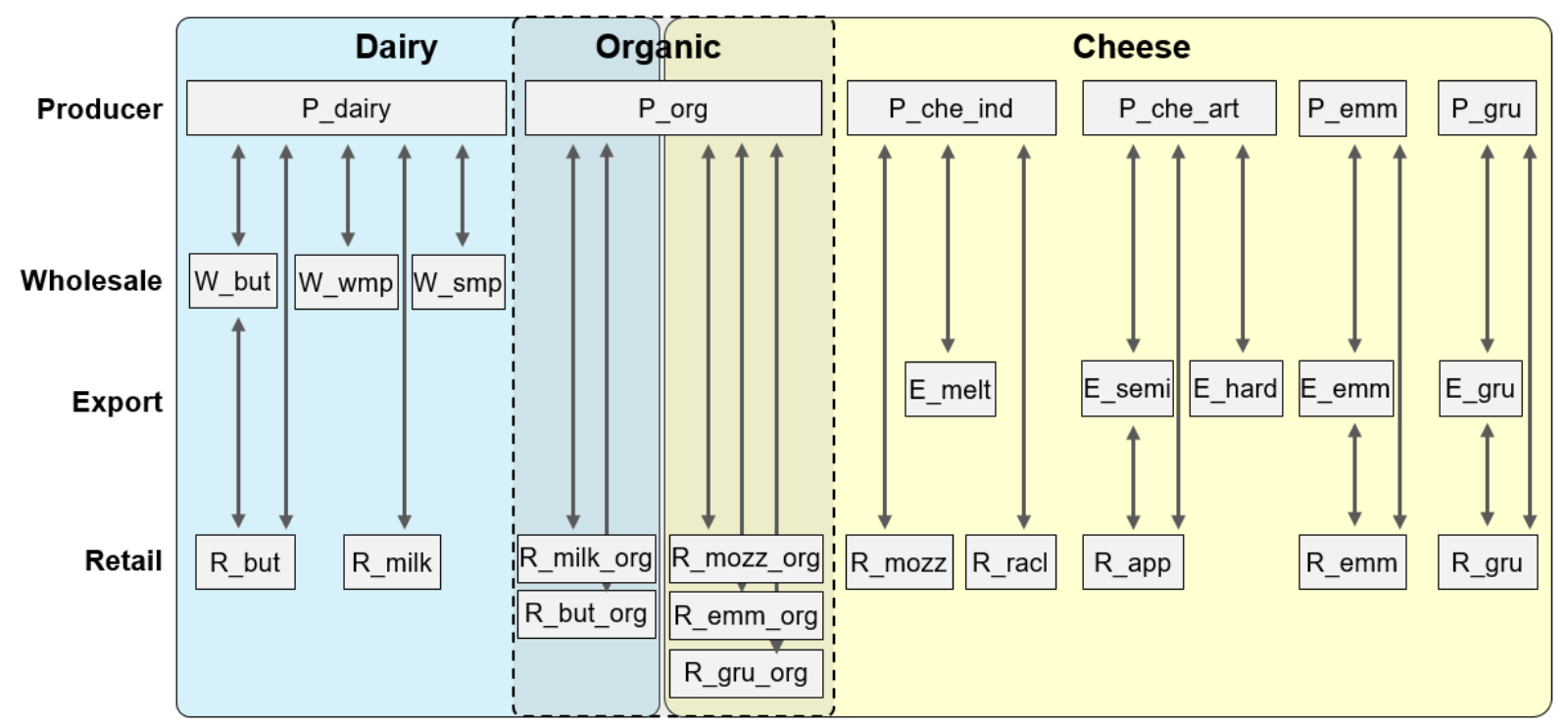

Figure 1: Relationships between included milk, dairy and cheese prices

Source: own representation

\subsection{Methodology}

Seeking consistency and allowing for better comparability with other case studies (see Table 1), we followed the most widely used methodology for vertical price transmission analysis: Pairwise Johansen tests and subsequent Vector Error Correction Models (VECM) for cointegrated prices, or Vector Autoregressive Models (VAR) in first differences for non-cointegrated prices. Additionally, we tested for non-linear threshold cointegration, as well as for short- and long-run asymmetry. For detailed information on asymmetric price transmission models and their specifications, see review papers by Frey and Manera (2007) and Meyer and von CramonTaubadel (2004).

\subsubsection{Unit root and cointegration tests}

First, we analyzed the individual price series properties by applying lag-order selection criteria, standard Augmented Dickey Fuller (ADF) unit root and Kwiatkowski-Phillips-Schmidt-Shin (KPSS) stationarity tests. Second, for each potentially related price pair in one value chain 
(compare Figure 1), we tested the null hypothesis of no cointegration against linear cointegration by applying Johansen (1988) trace and eigenvalue tests and accounted for seasonality. However, this approach requires symmetric relationship between the prices. As we were also interested in potential asymmetries, we further tested for threshold cointegration as developed by Balke and Fomby (1997) and Enders and Granger (1998). We followed a model specification by Enders and Siklos (2001) with two-regime threshold cointegration. Like the linear EngleGranger (1987) two-stage approach, it first models a long-run cointegrating relationship between the two prices:

(1) $p 2_{t}=\beta_{0}+\beta_{1} p 1_{t}+\varepsilon_{t}$

In contrast to the linear model, the residuals of this cointegrating relationship can differ between the two regimes by including a Heaviside indicator $I_{t}$ :

(2) $\Delta \hat{\varepsilon}_{t}=\rho_{1} I_{t} \hat{\varepsilon}_{t-1}+\rho_{2}\left(1-I_{t}\right) \hat{\varepsilon}_{t-1}+\sum_{i=1}^{k} \varphi \Delta \hat{\varepsilon}_{t-i}+\mu_{t}$, with

(3) $I_{t}=1$ if $\hat{\varepsilon}_{t-1} \geq 0$, and 0 otherwise; or

(4) $I_{t}=1$ if $\Delta \hat{\varepsilon}_{t-1} \geq 0$, and 0 otherwise

$\mathrm{K}$ is the number of lags, selected by minimizing AIC. The Heaviside indicator for the threshold can be specified in two different ways. If it depends on the lagged residual in levels (Equation 3), we get a Threshold Autoregression (TAR) model. If it depends on changes of the lagged residual (Equation 4), we get a Momentum Threshold Autoregression (MTAR) model. While the TAR model accounts for asymmetric "deep" movement, the MTAR model is more concerned with asymmetries in "steep" variations and adjustments. For a detailed discussion on the two models, see Enders and Granger (1998), Enders and Siklos (2001), and Sun (2011). We specified both TAR and MTAR models and decided based on AIC, which one was more accurate, as recommended by Enders and Siklos (2001). For both cases, we set the threshold value equal to zero because we were interested in comparable asymmetries across product pairs. ${ }^{8}$

These models allow for asymmetric long-run adjustment. To test whether this long-run relationship is significant, we applied F-tests with the null of no cointegration $\left(H_{01}: \rho_{1}=\rho_{2}=0\right)$

\footnotetext{
8 Alternatively, there are search methods to determine consistent estimates for the threshold value (Chan 1993).
} 
against the estimated threshold cointegration. ${ }^{9}$ Additionally, we tested the null of linear, symmetric cointegration $\left(H_{02}: \rho_{1}=\rho_{2}\right)$ with a standard F-test. ${ }^{10}$

\subsubsection{VECM and VAR models}

Depending on the outcome of the linear and threshold cointegration tests, we chose different models to estimate the pairwise price transmission. For linearly cointegrated price pairs, we first estimated symmetric VECMs (Equation 5).

(5) $\left[\begin{array}{l}\Delta p 1_{t} \\ \Delta p 2_{t}\end{array}\right]=\left[\begin{array}{l}\theta_{p 1} \\ \theta_{p 2}\end{array}\right]+\left[\begin{array}{l}\alpha_{p 1} \\ \alpha_{p 2}\end{array}\right]\left[E C T_{t-1}\right]+\sum_{i=1}^{k}\left[\begin{array}{ll}\delta_{p 1 j} & \rho_{p 1 j} \\ \delta_{p 2 j} & \rho_{p 2 j}\end{array}\right]\left[\begin{array}{c}\Delta p 1_{t-i} \\ \Delta p 2_{t-i}\end{array}\right]+\left[\begin{array}{c}\omega_{p 1} \\ \omega_{p 2}\end{array}\right]\left[M_{t}\right]+\left[\begin{array}{c}\varepsilon_{p 1 t} \\ \varepsilon_{p 2 t}\end{array}\right]$

p1 and p2 represent the two respective prices (in logarithms), $\Delta$ denotes changes in first differences, $M_{t}$ are monthly dummy variables (1-11) to capture seasonality, and lag length k is chosen according to a minimized Bayesian information criterion (BIC). The Error Correction Term (ECT) measures how previous periods departed from the long-run equilibrium, including a constant in cointegration $\left(E C T_{t-1}=p 2_{t-1}-\beta_{0}-\beta_{1} p 1_{t}\right)$. The ECT hence represents the cointegrating vector and is zero in the long-run. Over time, however, positive or negative deviations can occur, as the prices can meander loosely around this equilibrium. Given the construction of the ECT, for an adjustment towards the joint equilibrium zero, we expect $\alpha_{p 1}$ to be negative and $\alpha_{p 2}$ to be positive. For threshold-integrated price pairs, and to account for asymmetries, we re-specified Equation 5 into Equation 6.

(6) $\left[\begin{array}{l}\Delta p 1_{t} \\ \Delta p 2_{t}\end{array}\right]=\left[\begin{array}{c}\theta_{p 1} \\ \theta_{p 2}\end{array}\right]+\left[\begin{array}{c}\alpha_{p 1}^{+} \\ \alpha_{p 2}^{+}\end{array}\right] E_{t-1}^{+}+\left[\begin{array}{c}\alpha_{p 1}^{-} \\ \alpha_{p 2}^{-}\end{array}\right] E_{t-1}^{-}+\sum_{i=1}^{k}\left[\begin{array}{cc}\delta_{p 1 j}^{+} & \rho_{p 1 j}^{+} \\ \delta_{p 2 j}^{+} & \rho_{p 2 j}^{+}\end{array}\right]\left[\begin{array}{c}\Delta p 1_{t-i}^{+} \\ \Delta p 2_{t-i}^{+}\end{array}\right]+$ $\sum_{i=1}^{k}\left[\begin{array}{cc}\delta_{p 1 j}^{-} & \rho_{p 1 j}^{-} \\ \delta_{p 2 j}^{-} & \rho_{p 2 j}^{-}\end{array}\right]\left[\begin{array}{c}\Delta p 1_{t-i}^{-} \\ \Delta p 2_{t-i}^{-}\end{array}\right]+\left[\begin{array}{l}\varepsilon_{p 1 t} \\ \varepsilon_{p 2 t}\end{array}\right]$

The error correction term is based on threshold cointegration (see Equations 2-4), and therefore defined slightly differently and denoted as $E$, instead of $E C T$. We split it into $E_{t-1}^{+}=I_{t} \hat{\varepsilon}_{t-1}$ and $E_{t-1}^{-}=\left(1-I_{t}\right) \hat{\varepsilon}_{t-1}$, with the Heaviside indicator depending on the model specification (TAR or MTAR) and the threshold set equal to zero. To account for asymmetries, we split $E$ into positive and negative values and estimated separate error correcting coefficients $\alpha^{+}$and

9 Due to a non-normal test statistical distribution, we used the critical values listed in Enders and Siklos (2001) and extended by Wane et al. (2004).

10 We chose this procedure over the Hansen-Seo test (2002), which also tests the null hypothesis of linear cointegration against the alternative of threshold cointegration, because of its low power in the presence of asymmetric adjustment. Indeed, for our sample, the Hansen-Seo test did not reject the null of linear cointegration for any of the price pairs (see Appendix Table A4). 
$\alpha^{-}$to see whether the adjustment took place at a different speed for positive and negative deviations. We tested whether this difference was significant for each equation by testing $\mathrm{H}_{03}$ : $\alpha_{p 1}{ }^{+}=\alpha_{p 1}{ }^{-}$and $\mathrm{H}_{04}: \alpha_{p 2}{ }^{+}=\alpha_{p 2}{ }^{-}$.

Also, autoregressive effects and lagged variables of each price can incorporate asymmetries. Therefore, we tested for a cumulative asymmetric effects of the lagged price values of one variable on the other: $\mathrm{H}_{05}: \sum_{i=1}^{k}\left[\delta_{p 1 j}^{+} \rho_{p 1 j}^{+}\right]=\sum_{i=1}^{k}\left[\delta_{p 1 j}^{-} \rho_{p 1 j}^{-}\right]$for the influence of lagged $\mathrm{p} 1$ changes on $\Delta \mathrm{p} 2$; ; and $\mathrm{H}_{06}: \sum_{i=1}^{k}\left[\delta_{p 2 j}^{+} \rho_{p 2 j}^{+}\right]=\sum_{i=1}^{k}\left[\delta_{p 2 j}^{-} \rho_{p 2 j}^{-}\right]$for lagged $\mathrm{p} 2$ changes on $\Delta \mathrm{p} 1_{\mathrm{t}}$. One can also test for asymmetric effects of individual price lags (see Frey and Manera 2007, Sun 2011), but because of the large number of price pairs tested, we did not apply such a test here.

For non-cointegrated prices, we set up VAR models in first differences (equation 7). In this case, there was no long-run relationship between the prices. Yet, we allowed for asymmetric short-term effects by splitting the lagged values into positive and negative values (equation 8). As in the VECM specification above, we then tested for cumulative asymmetric effects.

(7) $\left[\begin{array}{l}\Delta p 1_{t} \\ \Delta p 2_{t}\end{array}\right]=\left[\begin{array}{l}\theta_{p 1} \\ \theta_{p 2}\end{array}\right]+\sum_{i=1}^{k}\left[\begin{array}{ll}\delta_{p 1 j} & \rho_{p 1 j} \\ \delta_{p 2 j} & \rho_{p 2 j}\end{array}\right]\left[\begin{array}{l}\Delta p 1_{t-i} \\ \Delta p 2_{t-i}\end{array}\right]+\left[\begin{array}{c}\omega_{p 1} \\ \omega_{p 2}\end{array}\right]\left[M_{t}\right]+\left[\begin{array}{l}\varepsilon_{p 1 t} \\ \varepsilon_{p 2 t}\end{array}\right]$

(8) $\left[\begin{array}{l}\Delta p 1_{t} \\ \Delta p 2_{t}\end{array}\right]=\left[\begin{array}{l}\theta_{p 1} \\ \theta_{p 2}\end{array}\right]+\sum_{i=1}^{k}\left[\begin{array}{cc}\delta_{p 1 j}^{+} & \rho_{p 1 j}^{+} \\ \delta_{p 2 j}^{+} & \rho_{p 2 j}^{+}\end{array}\right]\left[\begin{array}{c}\Delta p 1_{t-i}^{+} \\ \Delta p 2_{t-i}^{+}\end{array}\right]+\sum_{i=1}^{k}\left[\begin{array}{cc}\delta_{p 1 j}^{-} & \rho_{p 1 j}^{-} \\ \delta_{p 2 j}^{-} & \rho_{p 2 j}^{-}\end{array}\right]\left[\begin{array}{c}\Delta p 1_{t-i}^{-} \\ \Delta p 2_{t-i}^{-}\end{array}\right]+\left[\begin{array}{c}\omega_{p 1} \\ \omega_{p 2}\end{array}\right]\left[M_{t}\right]+\left[\begin{array}{c}\varepsilon_{p 1 t} \\ \varepsilon_{p 2 t}\end{array}\right]$

For price pairs with weak or nearly significant cointegration, we tried different model specifications to see ex-post, whether or not there was an economically meaningful long-run (threshold) cointegration and reported the model with the best fit. ${ }^{11}$

\section{Results}

\subsection{Unit root and cointegration test results}

Before specifying the models, we carefully tested all price series individually, and then pairwise on their statistical properties. Figure 2 illustrates the testing procedure and the results schematically, while the detailed test results are documented in appendix tables A1 - A3.

\footnotetext{
11 For value chains with prices of three stages available, we also tested for joint cointegration and price transmission among all three prices simultaneously, including producer, export or wholesale, and retail price as endogenous variables. As the results were qualitatively the same and parameter comparison and interpretation was easier for price pairs, we only reported pairwise model results here. Results for the overall value chain models are available on request.
} 


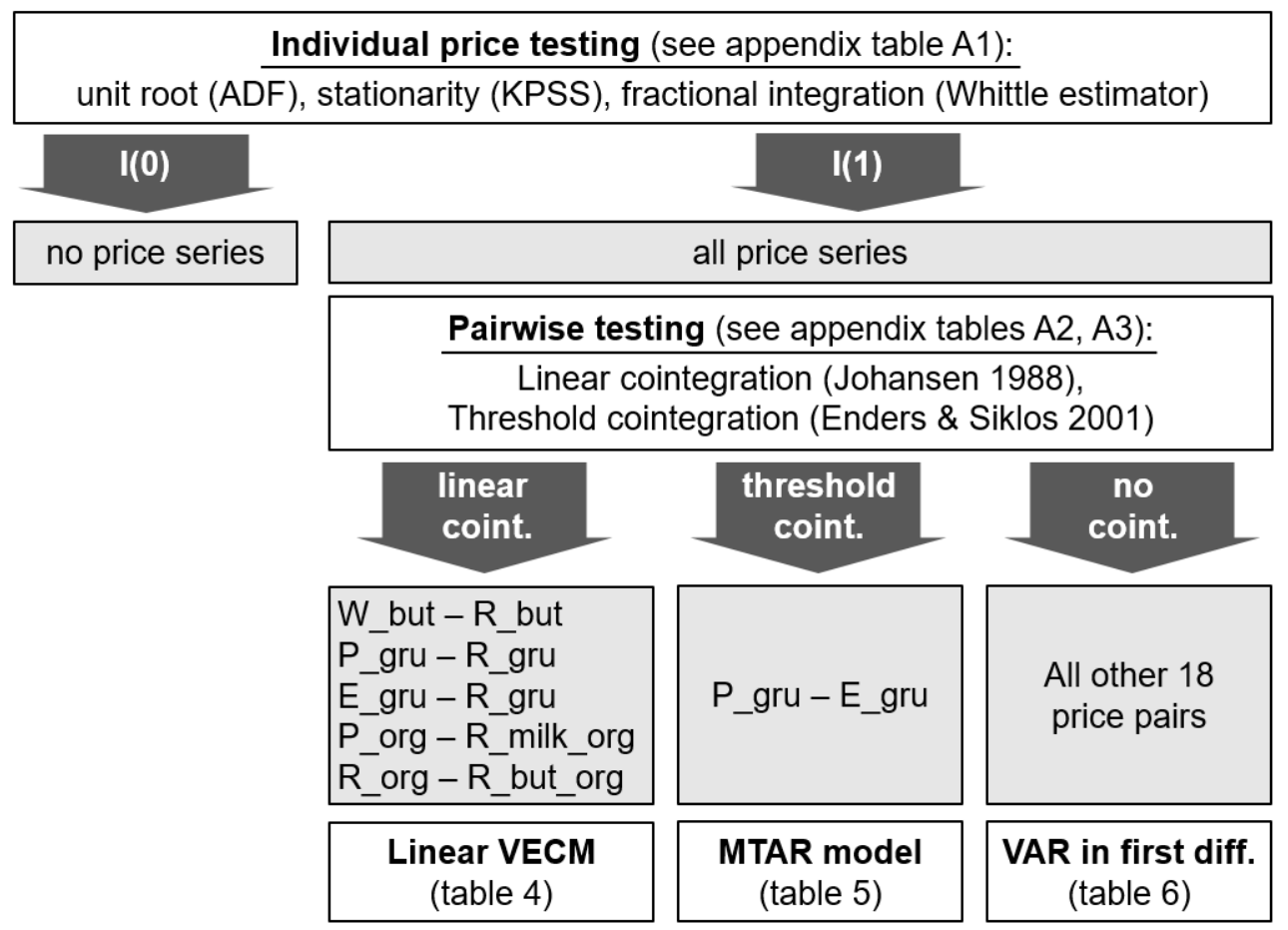

ADF = Augmented Dickey Fuller, KPSS $=$ Kwiatkowski-Phillips-Schmidt-Shin, MTAR $=$ Momentum Threshold Autoregression, VAR $=$ Vector Autoregressive, VECM $=$ Vector Error Correction Model Source: own representation

\section{Figure 2: Schematic summary of unit root and cointegration tests}

Unit root and stationarity tests clearly identified most price series as integrated of order one (I(1)). For some prices, however, both the null of stationarity (KPSS) and of a unit root (ADF) could not be rejected. For these cases, we checked for fractional integration by applying the Whittle estimator, introduced by Künsch (1987) and tested for consistency in the unit root case by Phillips and Shimotsu (2004). We found that on a 1\% significance level, a rank=1, that is, a unit root, could not be rejected and therefore continued to treat all prices as I(1) processes.

Next, we executed Johansen trace and eigenvalue tests for linear cointegration, including a constant in cointegration, seasonal dummies, and lag length according to BIC. Only for one out of 24 price pairs, the null of no cointegration $(r=0)$ could clearly be rejected at the $1 \%$ significance level in both test specifications: for the relationship between butter wholesale and retail prices. For the three Gruyère price pairs and for the relationship between organic producer prices and retail prices of organic milk and butter, the results were not clear. Here, the null of no cointegration was rejected between the $1 \%$ and $10 \%$ level, depending on the test specification. ${ }^{12}$ For

\footnotetext{
12 In both trace and eigenvalue, as in small samples, the trace tests can be more distorted, whereas the maximum eigenvalue tests can have a lower power (Lütkepohl et al. 2001). In our case, both tests led to very similar conclusions.
} 
these cases, we set up VECMs and check ex-post whether there is meaningful cointegration. For all other price pairs, the Johansen test found no long-run cointegration.

Threshold cointegration with asymmetric adjustment, as described in section 3, was only found between Gruyère producers and export prices, and is best specified by the MTAR model. Between butter wholesale and retail prices, the test rejected the null of no cointegration $\left(\mathrm{H}_{02}\right.$ : $\rho_{1}=\rho_{2}=0$ ) for both the TAR and MTAR specification, but without significant threshold effects or asymmetric adjustment. Hence, we consider this price pair linearly cointegrated, as found by the Johansen test. For some other price pairs in the MTAR model, the symmetric adjustment hypothesis $\left(\mathrm{H}_{02}: \rho_{1}=\rho_{2}\right)$ was rejected at the $5 \%$ level, but the cointegration link itself was not significant.

\subsection{Vector error correction model results}

Table 3 shows the linear VECM specialization for the price pairs considered cointegrated by the Johansen test. In the dairy chain, we estimated a linear price transmission elasticity of 0.82 from butter wholesale to retail prices, with the retail price adjusting to the joint equilibrium $\left(\alpha_{\mathrm{p} 2}\right.$ $=0.17)$, and some weak reaction by the wholesale price $\left(\alpha_{\mathrm{p} 1}=0.03\right)$, but into an error amplifying, rather than error correcting direction. In the cheese chain, Gruyère producers and export prices both seemed to follow the retail price ( $\alpha$ of -0.16 and -0.10 ), implying an upstream price transmission. For organic prices, retail milk and butter adapted to a joint equilibrium with the organic producer price, but also at a rather low speed (milk: $8 \%$ error correction per month; butter 12\% error correction per month) and at a negative price transmission elasticity, indicating that prices would move into opposite directions, which was surprising and did not make sense economically. Therefore, we additionally estimated VAR models, assuming no meaningful cointegration. For all the linearly cointegrated price pairs, splitting the ECT into positive and negative values and applying F-tests revealed that there were no significant asymmetries in adjustment (Appendix Table A5). Therefore, we adhered to the more parsimonious symmetric model. 
Table 3: Key parameters of linear VECM specification for cointegrated price pairs

\begin{tabular}{|c|c|c|c|c|c|c|c|c|c|c|}
\hline \multicolumn{2}{|c|}{ Tested variable pair } & \multirow[b]{2}{*}{ lags } & \multicolumn{2}{|c|}{ Coint. Vector } & \multicolumn{2}{|c|}{ Adjustment parameters } & \multicolumn{2}{|c|}{ Model Fit } & \multicolumn{2}{|c|}{ Asymmetry test } \\
\hline $\mathrm{p} 1$ & $\mathrm{p} 2$ & & $\begin{array}{c}\text { PT } \\
\text { elast. }\end{array}$ & const. & $\alpha_{\mathrm{p} 1}$ & $\alpha_{\mathrm{p} 2}$ & $\begin{array}{c}\operatorname{adj} \cdot R^{2} \\
\text { p1-equ. }\end{array}$ & $\begin{array}{l}\mathrm{R}^{2} \\
\text { equ. }\end{array}$ & $\alpha_{\mathrm{p} 1}{ }^{+}=\alpha_{\mathrm{p} 1}^{-}$ & $\alpha_{\mathrm{p} 2}{ }^{+}=\alpha_{\mathrm{p} 2}$ \\
\hline \multicolumn{11}{|c|}{ Dairy chain } \\
\hline W_but & R_but & 2 & 0.82 & 0.50 & $0.03 *$ & $0.17^{* * *}$ & 0.00 & 0.20 & n.s. & n.s. \\
\hline \multicolumn{11}{|c|}{ Cheese chain } \\
\hline P_gru & R_gru & 4 & 0.35 & -5.44 & $-0.16 * * *$ & 0.02 (n.s.) & 0.28 & 0.47 & n.s. & n.s. \\
\hline E_gru & R_gru & 4 & 1.94 & -8.37 & $-0.10 * * *$ & 0.00 (n.s.) & 0.24 & 0.51 & n.s. & n.s. \\
\hline \multicolumn{11}{|c|}{ Organic chain } \\
\hline P_org & R_milk_org & 2 & -1.48 & -3.53 & -0.03 (n.s.) & $0.08 * * *$ & 0.68 & 0.09 & n.s. & n.s. \\
\hline P_org & R_but_org & 2 & -0.89 & -3.17 & $-0.04($ n.s. $)$ & $0.12 * * *$ & 0.68 & 0.18 & n.s. & n.s. \\
\hline
\end{tabular}

Note: $* / * * * * *$ represent $10 / 5 / 1 \%$ significance level, (n.s.) = not significant at $10 \%$ level; ECT = error correction term Model with prices in logarithms, incl. 11 seasonal dummies, lag selection acc. to Schwarz criterion. Split pos. and neg. ECT not listed here, as none of the differences proved significant (see appendix).

The threshold cointegration test identified only one price pair to be threshold cointegrated and asymmetrically related; the Gruyère producer and export price, for which the threshold VECM specification is reported in Table 4. The adjustment parameters $\alpha$ of both the producer and export price are only partly significant, with significant adjustment by the producer price and no significant asymmetry in the export price adjustment. This means that producer prices respond faster to price increases than to decreases in export prices. Further, some short-term asymmetries were found; while negative past producer price changes influence the export price $\left(\Delta \mathrm{p} 1 \_11 . n e g=0.35\right)$, positive changes do not. Even through the cointegrating relationship and these parameters are statistically significant, the overall model fit is quite weak (Adj.R2 $=0.11$ and 0.15 for both response equations), hinting at weak cointegration and adjustment processes. 
Table 4: Asymmetric Threshold VECM results for Gruyère producer - export prices

\begin{tabular}{lcc}
\hline item & p1 estimate $($ E_gru) & P2 estimate (P_gru) \\
\hline (Intercept) & 0.00 & 0.01 \\
$\Delta \mathrm{p} 1$ 11.pos & -0.03 & -0.26 \\
$\Delta \mathrm{p} 1$ 11.neg & 0.05 & $0.35 *$ \\
$\Delta \mathrm{p} 2$ 11.pos & $-0.16 *$ & $-0.35 * * *$ \\
$\Delta \mathrm{p} 2$ 11.neg & 0.04 & $-0.31 * *$ \\
$\alpha^{+}$ & $-0.17 * * *$ & 0.06 \\
$\alpha^{-}$ & 0.03 & $0.12 * *$ \\
$\alpha^{+}=\alpha^{-}\left(\mathrm{H} 03\right.$ and $\left.\mathrm{H}_{04}\right)$ & $16.26 * * *$ & 0.60 \\
Cumulative $\Delta \mathrm{p} 1^{+}=$Cumulative $\Delta \mathrm{p} 1^{-}\left(\mathrm{H}_{05}\right)$ & 0.12 & $3.86 *$ \\
Cumulative $\Delta \mathrm{p} 2^{+}=$Cumulative $\Delta \mathrm{p} 2^{-}\left(\mathrm{H}_{06}\right)$ & 1.28 & 0.02 \\
Adj-R2 & 0.11 & 0.15 \\
\hline
\end{tabular}

$* / * * / * * *$ represent $10 / 5 / 1 \%$ significance level

Model specification based on previous threshold cointegration tests: MTAR model with 1 lag and threshold set to zero. Cointegrating vector: $\mathrm{p}_{2}-1.13 \mathrm{p}_{1}+2.41$. To test for cumulative asymmetric effects, the effect on the respective other price matters (H05: column 2, H06: column 1).

Note: We changed the ECT signs from the original R output, based on package APT, to be consistent with the sign interpretation of the linear VECM output in Table 3. For the R package documentation, see https://cran.r-project.org/package=apt.

\subsection{Vector autoregressive model results}

For the remaining non-cointegrated price pairs, we set up VAR models in first differences. Table 5 summarizes the key parameters. We can see that there are only few cross-effects between the price pairs ( $\Delta$ p1.lagged influencing $\Delta \mathrm{p} 2$ and vice versa). Along the dairy chain, past producer price changes positively influence wholesale prices (butter and milk powder), and the organic producer price positively influences the organic butter and mozzarella price. Further, we tested for short-term asymmetries through cumulative asymmetric effects of past p1changes on $\Delta \mathrm{p} 2_{\mathrm{t}}\left(\mathrm{H}_{05}\right)$ and of past $\mathrm{p} 2$-changes on the $\Delta \mathrm{p} 1_{\mathrm{t}}\left(\mathrm{H}_{06}\right)$ but could not detect any asymmetries. For none of the price pairs in either direction, the null hypothesis of symmetric cumulative lag effects can be rejected at a 5\% significance level (see Table A6 in the appendix for details). 
Table 5: Key parameters of VAR in first difference model for non-cointegrated price pairs

\begin{tabular}{|c|c|c|c|c|c|c|c|c|c|c|c|}
\hline \multicolumn{2}{|c|}{ Tested variable pair } & \multicolumn{4}{|c|}{ P1-equation } & \multicolumn{4}{|c|}{ P2-equation } & \multicolumn{2}{|c|}{ Model Fit } \\
\hline P1 & $\mathrm{P} 2$ & $\Delta \mathrm{P} 1.11$ & $\Delta \mathrm{P} 1.12$ & $\Delta \mathrm{P} 2.11$ & $\Delta \mathrm{P} 2.12$ & $\Delta \mathrm{P} 1.11$ & $\Delta \mathrm{P} 1.12$ & $\Delta \mathrm{P} 2.11$ & $\Delta \mathrm{P} 2.12$ & $\begin{array}{l}\text { adj. } R^{2} \quad a \\
p_{1} \text {-equ. } p\end{array}$ & $\begin{array}{l}j \cdot R^{2} \\
\text { equ. }\end{array}$ \\
\hline \multicolumn{12}{|c|}{ Dairy chain } \\
\hline$P_{-}$dai & W_but & $0.18 * *$ & $0.18 * *$ & -0.03 & -0.23 & $0.16^{* * *}$ & 0.01 & 0.00 & 0.10 & 0.46 & 0.05 \\
\hline P_dai & W_smp & 0.14 & $0.15 *$ & $0.12 *$ & -0.02 & 0.12 & $0.17 *$ & -0.12 & 0.05 & 0.47 & 0.02 \\
\hline P_dai & W_wmp & $0.20 * *$ & 0.15 & -0.09 & 0.01 & $0.10 *$ & $0.16 * * *$ & -0.06 & 0.07 & 0.46 & 0.14 \\
\hline$P$ _dai & R_milk & $0.16^{*}$ & $0.17 * *$ & 0.08 & -0.12 & 0.01 & $0.09 *$ & 0.11 & 0.06 & 0.46 & 0.04 \\
\hline P_dai & R_but & $0.18 * *$ & $0.18 * *$ & -0.02 & $-0.13 * *$ & $0.17 *$ & 0.09 & $-0.33 * * *$ & $-0.27 * * *$ & 0.47 & 0.14 \\
\hline \multicolumn{12}{|c|}{ Cheese chain } \\
\hline P_che_ind & R_mozz & -0.07 & 0.14 & 0.03 & 0.08 & 0.12 & -0.07 & $-0.17 * *$ & 0.07 & 0.64 & 0.04 \\
\hline P_che_ind & R_racl & -0.05 & $0.18 * *$ & $0.10 * *$ & 0.07 & -0.13 & 0.21 & $-0.70 * * *$ & $-0.39 * * *$ & 0.65 & 0.42 \\
\hline P_che_ind & E_melt & -0.09 & $0.14 *$ & -0.01 & -0.02 & 0.31 & 0.12 & $-0.64 * * *$ & -0.41 & 0.64 & 0.29 \\
\hline P_che_art & E_hard & 0.10 & 0.04 & 0.02 & 0.01 & 0.00 & 0.09 & $-0.22 * * *$ & $-0.14 *$ & 0.29 & 0.22 \\
\hline P_che_art & E_semi & 0.09 & 0.04 & $0.03 *$ & 0.00 & 0.13 & 0.50 & $-0.25 * * *$ & $-0.19 * *$ & 0.30 & 0.27 \\
\hline P_che_art & R_app & 0.09 & 0.03 & -0.05 & -0.05 & -0.03 & 0.18 & $-0.62 * * *$ & -0.13 & 0.29 & 0.29 \\
\hline E_semi & R_app & -0.25 & -0.20 & 0.05 & 0.08 & 0.05 & 0.06 & $-0.62 * * *$ & -0.11 & 0.26 & 0.31 \\
\hline P_emm & E_emm & -0.01 & 0.12 & $0.12 *$ & -0.02 & 0.18 & $0.21 *$ & -0.12 & -0.01 & 0.25 & 0.12 \\
\hline P_emm & R_emm & 0.02 & 0.13 & -0.04 & 0.00 & 0.04 & -0.01 & $-0.63 * * *$ & -0.11 & 0.23 & 0.31 \\
\hline E_emm & R_emm & -0.07 & 0.03 & 0.08 & 0.00 & $0.17 * *$ & 0.12 & $-0.65 * * *$ & $-0.14 *$ & 0.10 & 0.34 \\
\hline \multicolumn{12}{|c|}{ Organic chain } \\
\hline P_org & R_milk_org & $-0.17^{*}$ & 0.14 & 0.06 & 0.10 & $0.11^{*}$ & 0.08 & $-0.39^{* * *}$ & $-0.25^{* * *}$ & 0.68 & 0.08 \\
\hline P_org & R_but_org & $-0.15^{*}$ & $0.15^{*}$ & 0.13 & -0.04 & $0.11^{*}$ & $0.24 * * *$ & $-0.32 * * *$ & $-0.16^{* *}$ & 0.69 & 0.20 \\
\hline P_org & R_emm_org & $-0.16^{*}$ & $0.17^{*}$ & 0.04 & -0.01 & -0.18 & -0.05 & $-0.47 * * *$ & -0.07 & 0.68 & 0.21 \\
\hline P_org & R_gru_org & $-0.15^{*}$ & $0.16^{*}$ & -0.03 & 0.02 & -0.07 & 0.12 & $-0.43^{* * *}$ & $-0.33^{* * *}$ & 0.68 & 0.17 \\
\hline P_org & R_mozz_org & $-0.15^{*}$ & $0.16^{*}$ & $0.12 *$ & $0.12 *$ & $0.31^{* * *}$ & $0.19^{*}$ & $-0.49 * * *$ & $-0.23^{* * *}$ & 0.69 & 0.24 \\
\hline
\end{tabular}

Note: $* / * * * * *$ represent $10 / 5 / 1 \%$ significance level; lag selection acc. to AIC

Included variables: logged variables, monthly dummies for raw milk, 2 lags (following BIC), constant as deterministic regressor

\section{Discussion}

\subsection{Summary and integration of the results}

The analysis of price transmission along Swiss dairy and cheese chains revealed only weak price links between prices at different value chain levels, as Figure 3 illustrates. We found no convincing evidence for long-run vertical price transmission, neither in dairy nor cheese chains. Even the few price pairs (six out of 24), which seem (threshold) cointegrated, do not allow us to draw clear conclusions; they are partly found in the dairy chain (W_but, R_but), cheese chain (all Gruyère levels), and organic chain ( $\mathrm{P} \_$org, $\mathrm{R}$ _milk/but_org). In all cases, the estimated speed of price transmission is rather low, with less than $20 \%$ of the temporary disequilibrium 
corrected for within one month, and rather poor model fit for the response equation of the adjusting price (Adj.R2 < 0.3). An asymmetric relationship was only identified between Gruyère producers and export prices, with positive asymmetric adjustment by the producer price. This means that increases in export prices are passed on to producer prices more strongly than decreases in export prices.

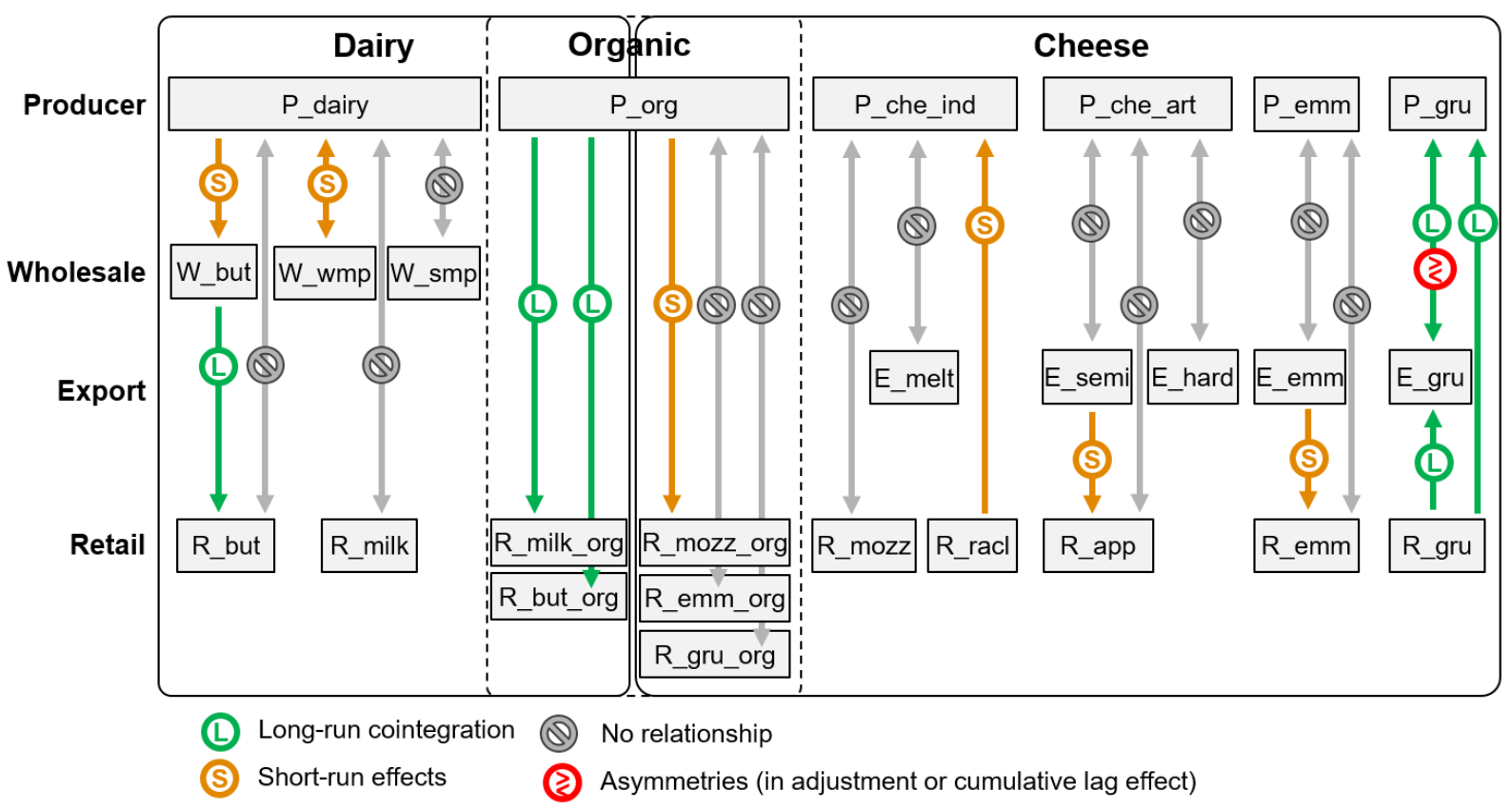

Note: Illustrative results summary, with decision based on $5 \%$ significance level of the respective tests. For detailed models and results, see other tables.

\section{Figure 3: Illustrative result summary of price transmission along Swiss milk chains}

Our results are contrary to previous findings for milk markets in several developed and developing countries, as most of them find long-run asymmetric price transmission (see Table 1). Often, such imperfect or lacking price transmission is interpreted as a consequence of market power exercised by highly concentrated, rent-capturing processors or retailers. However, we could not confirm that price pass-through is less complete in the highly concentrated dairy sector than in artisanal and AOP cheese value chains with less, and more closely linked actors. Also higher price transparency between different stages in specialized artisanal cheese processing than for the industrial dairy processing does not lead to systematic differences in vertical price transmission behavior. Hence, our analysis could not confirm our initial hypothesis of faster and more complete price pass-through in cheese than in dairy markets. In the following, we discuss other potential reasons for the weak price transmission links in Swiss milk and cheese chains. 


\subsection{Potential reasons for low or weak price transmission}

In the literature, several reasons for weak price transmission besides market power have been identified including the existence of inventory stocks, menu costs to changing prices, or contracts with fixed prices (e.g., Vavra and Goodwin 2005). All of them may apply in our case as in any other case. Additionally, there are factors that apply specifically to our analysis, such as statistical properties of the used price data, and Switzerland-specific factors, which we will discuss next.

\subsubsection{Statistical properties of price series}

The most straightforward explanation may be our limited data availability. Our sample size of 171 observations per price series is rather small. Especially if error correction is slow, markets spend long periods out of equilibrium, making the equilibrium, i.e., a cointegrating relationship, itself harder to detect. This is even more the case when non-linearities and structural breaks are present, i.e., when there is not one constant long-run relationship. Moreover, we work with monthly price data. Hence, any variation that takes place within a month is averaged away, and with it much possible evidence of error correction at higher frequencies.

Further, the statistical properties of the included export and retail price series may bias the results of cointegration and adjustment estimates.

For retail data, there are two major issues influencing price transmission estimation: temporary sales promotions and aggregation across retailers. In food retail, promotional sales are a frequent phenomenon, that is, significant temporary price reductions that are unrelated to cost changes (Hosken and Reiffen 2001). As such promotions are marketing tools and not part of the cost pass-through, they can bias the results of price transmission analysis, or at least decrease the efficiency of estimation by adding unexplained price variations. Hence, it has been suggested they be filtered out (Tifaoui and von Cramon-Taubadel 2017). Yet, even then, scanner data studies have shown that the remaining reference prices follow discontinuous jump processes and thus do not allow for cointegration models, which assume continuous adjustment (Chahrour 2011, Loy et al. 2015). The downward-spikes in our price series (see appendix, especially figures A4, A5) and the observable pricing strategies of Swiss retailers hint at such temporary promotions. However, we used aggregate data and cannot clearly identify and remove promotional sales prices. Further, the prices are aggregated across several retailers. As von Cramon-Taubadel et al. (2006) showed, this can lead to miss-specified estimations of the actual price transmission at the individual store level. The Swiss retail price data do not include discount stores, such as Aldi and Lidl, but only the largest retailers. While the discount market 
share is still rather low (jointly $8.3 \%$ in food retail, EDA 2017), they may still convey important price signals to the other players (Ailawadi and Keller 2004).

Also export prices are not necessarily good representatives of the overall price development. One issue is that export prices depend on the quality of the exported products (Hallak 2006). Therefore, we only included export prices for narrow product groups with comparable qualities, such as the AOP cheese brands, Emmentaler and Gruyère, or melted cheese. Still, we observed large short-term variations in export prices, which may depend on the quantities traded, package sizes, and remaining heterogeneity within the product categories, such as different age and ripening processes.

Consequently, for price transmission involving export or retail data, it is not surprising to see such little evidence of cointegration and adjustment. Yet, a visual inspection of the price series (appendix figures A1-A5) shows there is no apparent co-movement. Hence, it cannot be only due to data issues that we found no links between most of the prices.

\subsubsection{Industry structure}

In Section 2, we described the structure and characteristics of Swiss dairy and cheese value chains, and how this may influence vertical price transmission. However, we did not find systematical differences by processing use; they do not seem to be the decisive factors. Rather, the general characteristics of the Swiss milk sector may be relevant. According to Bakucs et al. (2014), a fragmented farm structure and high governmental support, as present in Switzerland, can contribute to low, asymmetric price transmission. Moreover, perishability has been identified as another driver of imperfect price transmission (Peltzman 2000, Serra and Goodwin 2003, Santeramo and von Cramon-Taubadel 2016), which might be relevant for highly perishable raw milk, that is, transmission between producer and wholesale or export prices.

At the retail level, the high concentration is frequently blamed for increasing market power and hindering price transmission, as described in Section 2. Additionally, milk products, especially fluid milk, are considered "signaling products" (Dickson and Urbany 1994, Binkley and Connor 1998). These prices are the reference on which consumers evaluate the overall retailer's price level. Therefore, irrespective of market power, retailers may make pricing decisions based on strategic considerations, and not based on the own purchase price of a specific good. Sexton and $\mathrm{Xia}$ (2018) stressed that pricing strategies are not set up and optimized for just one specific good, but for a larger basket of goods. There is empirical evidence that retail price setting accounts for interactions within and across product categories (Richards 2006, Thomassen et al. 2017). 


\subsubsection{High income and cost level in Switzerland}

Switzerland is a very high-income, and hence high-cost country, with an overall price level 59\% above EU average (Eurostat 2018). Therefore, it may also be that costs of non-commodity input prices are so high that they outweigh the changes in the agricultural input prices. This includes costs directly and indirectly linked to the dairy and cheese value chains, such as labor costs, transport, rent etc. Iten et al. (2003) and SECO (2008) showed that these costs are indeed higher in Switzerland than in EU countries. The fact that especially non-tradable goods and services are expensive can be explained by the Balassa-Samuelson effect (1964). ${ }^{13}$ Sax and Weder (2009) showed that this effect also holds for Switzerland. BAK Basel (2017) demonstrated that Swiss food retailers face significantly higher input, infrastructure, and labor costs than their EU neighbors and pass them on to consumers through food prices. For "perfect" milk price transmission along the value chain, we therefore do not expect price transmission elasticities to be unity, but equal to the share of the agricultural input raw milk in the industry's or retailer's cost function (McCorriston et al. 1998), which can be low in Switzerland. Yet, despite a lower numerical price transmission elasticity, we would expect to see a long-run relationship.

\section{Conclusion}

Our study analyzed vertical price transmission in the Swiss milk market by examining a total of 24 price pairs in dairy, cheese, and organic value chains. We found almost no evidence of long-run price transmission and no significant asymmetries for most price pairs. This result differs from the majority of studies in other countries, which found significant, asymmetric long-run price transmission, mostly from farm to retail milk prices.

We could not identify systematic differences between different chains. Our initial hypothesis that prices are passed on more fully and quickly in artisanal cheese value chains with high price transparency than in industrialized, highly concentrated dairy chains could not be confirmed. Industry concentration and value chain governance structures do not seem to be the decisive factors for whether or not prices are passed on between different value chain levels. Therefore, we could not clearly identify the reason for the lack of vertical price transmission in Swiss milk markets. Besides data limitations, more general conditions of the Swiss market, such as the high cost levels, a fragmented farm structure, and high governmental support, could hinder price transmission along the value chains.

13 The Balassa-Samuelson effect states that a high productivity in the tradable, relative to the non-tradable sector causes a wage increase in both sectors, and consequently, a price increase for non-tradable goods and services. 


\section{References}

Acosta, A., and Valdés, A. (2014). Vertical price transmission of milk prices: are small dairy producers efficiently integrated into markets? Agribusiness 30(1), 56-63.

Ailawadi, K. L., and Keller, K. L. (2004). Understanding retail branding: conceptual insights and research priorities. Journal of Retailing 80(4), 331-342.

Antonioli, F., and Santeramo, F. (2017). Vertical Price Transmission in Milk Supply Chain: Market Changes and Asymmetric Dynamics. Paper presented at the AIEAA Conference, June 15-16, Piacenza, Italy.

Aguiar, D. R., and Santana, J. A. (2002). Asymmetry in farm to retail price transmission: evidence from Brazil. Agribusiness 18(1), 37-48.

Bakucs, L. Z., and Fertő, I. (2008). Price transmission on the Hungarian milk market. Paper presented at the EAAE Congress, August 26-29, 2008, Ghent, Belgium.

Bakucs, Z., Fałkowski, J., and Fertő, I. (2012). Price transmission in the milk sectors of Poland and Hungary. Post-communist Economies 24(3), 419-432.

Bakucs, Z., Fałkowski, J., and Fertő, I. (2014). Does Market Structure Influence Price Transmission in the Agro-food Sector? A Meta-analysis Perspective. Journal of Agricultural Economics 65(1), 1-25.

BAK Basel (2017). Die Kosten des Schweizer Detailhandels im internationalen Vergleich. Eine Studie im Auftrag der Swiss Retail Federation. Available at https://www.bak-economics.com/fileadmin/documents/reports/BAKBASEL_Kosten_Detailhandel_internatio naler_Vergleich_Studie.pdf, last accessed 1 July 2018.

Balassa, B. (1964). The purchasing-power parity doctrine: a reappraisal. Journal of Political Economy 72(6), 584-596.

Balke, N. S., and Fomby, T. B. (1997). Threshold cointegration. International Economic Review, 38(3), 627-645.

Binkley, J. K., and Connor, J. M. (1998). Grocery market pricing and the new competitive environment. Journal of Retailing 74(2), 273-294. 
Bittmann, T., Holzer, P., and Loy, J.P. (2017). Seasonal Cost Pass-Through In The German Milk Market, Schriften der Gesellschaft für Wirtschafts- und Sozialwissenschaften des Landbaues e.V., Bd.52, 2017, S. 295 -302

Bolotova, Y. V., and Novakovic, A. M. (2012). The impact of the New York state milk price gouging law on the price transmission process and supermarket pricing strategies in the fluid whole milk market. Agribusiness 28(4), 377-399.

Bor, Ö., Ismihan, M., and Bayaner, A. (2014). Asymmetry in farm-retail price transmission in the Turkish fluid milk market. New Medit 13(2), 2-8.

Capps, O., and Sherwell, P. (2007). Alternative approaches in detecting asymmetry in farmretail price transmission of fluid milk. Agribusiness 23(3), 313-331.

Chahrour, R.A. (2011). Sales and price spikes in retail scanner data. Economics Letters 110(2), 143-146.

Chan, K.S. (1993). Consistency and limiting distribution of the least squares estimator of a threshold autoregressive model. The Annals of Statistics 21, 520-533.

Chavas, J.-P., and Mehta, A. (2004). Price Dynamics in a Vertical Sector: The Case of Butter. American Journal of Agricultural Economics 86 (4), 1078-1093.

Cornall, J. (2017, 14 December). Successful start for fair milk in Switzerland. The Dairy Reporter. Available at https://www.dairyreporter.com/Article/2017/12/14/Successfulstart-for-Fair-Milk-in-Switzerland, last accessed 1 July 2018.

Cutts, M., and Kirsten, J. (2006). Asymmetric price transmission and market concentration: An investigation into four South African agro-food industries. South African Journal of Economics 74(2), 323-333.

De Oliveira, L., Carvalho, M., Lucas, M., Henriques, P., and Peixe, F. (2015). Price Transmission on the Milk Portuguese Market, Agricultural Economics Review 16(1), 35-46.

Dickson, P. R., and Urbany, J. (1994). Retailer Reactions to Competitive Price Changes, Journal of Retailing 70, 1-21. 
EDA (2017). Detailhandel. Information by the Federal Department of Foreign Affairs. Available at https://www.eda.admin.ch/aboutswitzerland/de/home/wirtschaft/taetigkeitsgebiete/detailhandel.html

Enders, W., and Granger, C.W.J. (1998). Unit-root tests and asymmetric adjustment with an example using the term structure of interest rates. Journal of Business and Economic Statistics 16, 304-311.

Enders, W., and Siklos, P. L. (2001). Cointegration and threshold adjustment. Journal of Business \& Economic Statistics 19(2), 166-176.

Eurostat (2018). Comparative price levels of consumer goods and services. Available at http://ec.europa.eu/eurostat/en/web/products-datasets/-/TEC00120, last updated 19 June 2018, last accessed 1 July 2018.

Fałkowski, J. (2010). Price transmission and market power in a transition context: evidence from the Polish fluid milk sector. Post-communist Economies 22(4), 513-529.

Finger, R., Listorti, G., and Tonini, A. (2017). The Swiss payment for milk processed into cheese: ex post and ex ante analysis. Agricultural Economics 48(4), 437-448.

Flury, C., Sorg, L., and Giuliani, G. (2014). Evaluation der Zulagen für verkäste Milch und für Fütterung ohne Silage. Flury \& Giuliani Sàrl, Zürich. Available at https://ext.d-nsbpp.admin.ch/NSBExterneStudien/externestudien/419/fr/1624.pdf, last accessed 1 July 2018.

Frey, G., and Manera, M. (2007). Econometric models of asymmetric price transmission. Journal of Economic Surveys 21(2), 349-415.

Gregory, A. W., and Hansen, B. E. (1996). Residual-based tests for cointegration in models with regime shifts. Journal of Econometrics 70(1), 99-126.

Hallak, J. C. (2006). Product quality and the direction of trade. Journal of International Economics, 68(1), 238-265.

Haller, T. (2014). Abolition of the Milk Quota System in Switzerland. Burgdorf: Berner Fachhochschule. 
Hansen, B. E., and Seo, B. (2002). Testing for two-regime threshold cointegration in vector error-correction models. Journal of Econometrics 110(2), 293-318.

Heien, D. M. (1980). Markup pricing in a dynamic model of the food industry. American Journal of Agricultural Economics 62(1), 10-18.

Hosken, D., and Reiffen, D. (2001). Multiproduct retailers and the sale phenomenon. Agribusiness 17(1), 115-137.

Houck, J. P. (1977). An approach to specifying and estimating nonreversible functions. American Journal of Agricultural Economics 59(3), 570-572.

Iten, R., Peter, M., Vettori, A., and Menegale, S. (2003). Hohe Preise in der Schweiz: Ursachen und Wirkung. Swiss State Secretariat for Economic Affairs.

Jaffry, R., and Grigoryev, R. (2011). Asymmetric price transmission within the UK dairy supply chain. [online] University of Portsmouth:Centre for Economic Analysis and Policy. Available at http://www.dairyco.org.uk/resources-library/market-information/ apt-reports/apt-report-2011, last accessed 1 July 2018.

Johansen, S. (1988). Statistical analysis of cointegration vectors. Journal of Economic Dynamics and Control 12(2-3), 231-254.

Kharin, S. (2015). Vertical price transmission along the diary supply chain in Russia. Studies in Agricultural Economics 117(2), 80-85.

Kharin, S., Lajdova, Z., and Bielik, P. (2017). Price transmission on the Slovak dairy market. Studies in Agricultural Economics 119(3), 148-155.

Kinnucan, H. W., and Forker, O. D. (1987). Asymmetry in farm-retail price transmission for major dairy products. American Journal of Agricultural Economics 69(2), 285-292.

Künsch, H. (1987). Statistical aspects of self-similar processes. In Proc. First World Congress of the Bernoulli Society (Yu. Prokhorov and V. V. Sazanov, eds.) 1, 67-74. VNU Science Press, Utrecht.

Lajdová, Z., and Bielik, P. (2013). Vertical price transmission analysis: the case of milk in the Slovak dairy Sector. Applied Studies in Agribusiness and Commerce 7, 89-96. 
Lass, D. A. (2005). Asymmetric response of retail milk prices in the northeast revisited. Agribusiness 21(4), 493-508.

Liu, Y., Rabinowitz, A., and Xuan, C. (2017). Heterogeneity in Brand Effects on Farm-Retail Price Transmission: Evidence from Private Labels and Branded Products in Fluid Milk Market. In 2017 Annual Meeting, February 4-7, 2017, Mobile, Alabama (No. 252725). Southern Agricultural Economics Association.

Loy, J. P., Holm, T., Steinhagen, C., and Glauben, T. (2015). Cost pass-through in differentiated product markets: a disaggregated study for milk and butter. European Review of Agricultural Economics 42(3), 441-471.

Loy, J. P., Steinhagen, C., Weiss, C., and Koch, B. (2018). Price transmission and local market power: Empirical evidence from the Austrian gasoline market. Applied Economics 50(53), 5728-5746.

Lütkepohl, H., Saikkonen, P., and Trenkler, C. (2001). Maximum eigenvalue versus trace tests for the cointegrating rank of a VAR process. The Econometrics Journal 4(2), 287-310.

McCorriston, S., Morgan, C. W., and Rayner, A. J. (2001). Price transmission: the interaction between market power and returns to scale. European Review of Agricultural Economics 28(2), 143-159.

McCorriston, S., Morgan, C. W., and Rayner, A. J. (1998). Processing technology, market power and price transmission. Journal of Agricultural Economics 49(2), 185-201.

Ménard, C. (2004). The economics of hybrid organizations. Journal of Institutional and Theoretical Economics 160(3), 345-376.

Ménard, C. (2018). Organization and governance in the agrifood sector: How can we capture their variety? Agribusiness 34(1), 142-160.

Meyer, J., and von Cramon-Taubadel, S. (2004). Asymmetric price transmission: a survey. Journal of Agricultural Economics 55(3), 581-611.

Peltzman, S. (2000). Prices rise faster than they fall. Journal of Political Economy 108(3), 466502. 
Phillips, P. C., and Shimotsu, K. (2004). Local Whittle estimation in nonstationary and unit root cases. The Annals of Statistics 32(2), 656-692.

Reviron S., Chappuis J.-M., and Barjolle D. (2004). Vertical alliances for origin labelled food products: what is the most relevant economic model of analysis? Vertical alliances for origin labelled food products: what is the most relevant economic model of analysis. Role of institutions in rural policies and agricultural markets, Amsterdam, Elsevier BV, 239-254.

Reviron, S., Python, P., Gresset, F., Estève, M., and Bänninger, A. (2017). Wertverteilung in der Wertschöpfungskette. Schlussbericht. Nr. 3177. Agridea, Lausanne. Available at https://agridea.abacuscity.ch/de/ 2044, last accessed 1 July 2018.

Santeramo, F.G., and von Cramon-Taubadel, S. (2016). On Perishability and Vertical Price Transmission: empirical evidences from Italy. Bio-based and Applied Economics 5(2), 199-214.

Sax, C., and Weder, R. (2009). How to explain the high prices in Switzerland? Swiss Journal of Economics and Statistics 145(4), 463-483.

SBV (Schweizer Bauernverband) (2013). Der Schweizer Milchmarkt. 056-462 51 11. Available at https://www.sbv-usp.ch/fileadmin/sbvuspch/07_Preise/milch/131204_Milch markt_Schweiz_de.pdf, last accessed 1 July 2018.

SECO (2008). Preisinsel Schweiz. Berichte zur Erfüllung des Postulates David (05.3816), Swiss State Secretariat for Economic Affairs.

Serra, T., and Goodwin, B. K. (2003). Price transmission and asymmetric adjustment in the Spanish dairy sector. Applied Economics 35(18), 1889-1899.

Sexton, R. J., and Xia, T. (2018). Increasing Concentration in the Agricultural Supply Chain: Implications for Market Power and Sector Performance. Annual Review of Resource Economics, (0).

SMP (Schweizer Milkproduzenten) (2019). Schweizer Milchwirtschaft in Zahlen 2018/2019. Available at https://api.swissmilk.ch/wp-content/uploads/2019/06/brochure-smpschweizer-milchwirtschaft-in-zahlen-2018-2019-195000-de.pdf, last accessed 7 August 2019 
Stewart, H., and Blayney, D.P. (2011). Retail dairy prices fluctuate with the farm value of milk. Agricultural and Resource Economics Review 40(2), 201-217.

Sun, C. (2011). Price dynamics in the import wooden bed market of the United States. Forest Policy and Economics 13(6), 479-487.

Tifaoui, S., and Cramon-Taubadel, S. (2017). Temporary sales prices and asymmetric price transmission. Agribusiness 33(1), 85-97.

Tirole, J. (1988). The Theory of Industrial Organization. Cambridge, MA: The MIT press.

Thomassen, Ø., Smith, H., Seiler, S., and Schiraldi, P. (2017). Multi-category competition and market power: a model of supermarket pricing. American Economic Review 107(8), 2308-51.

TSM, SMP, SCM, and Agristat (2017). Milchstatistik der Schweiz 2016. Bern, September 2017. ISSN 1423- 4548

US Government Accountability Office (2004). Dairy Industry: Information on Milk Prices, Factors Affecting Prices, and Dairy Policy Options. Available at https:/www.gao.gov/ new.items/d0550.pdf, last accessed 1 July 2018.

Vavra, P., and Goodwin, B. K. (2005). Analysis of price transmission along the food chain. OECD Food, Agriculture, and Fisheries Papers No. 3. Paris: Organisation of Economic Cooperation and Development.

von Cramon-Taubadel, S., Loy, J. P., and Meyer, J. (2006). The impact of cross-sectional data aggregation on the measurement of vertical price transmission: An experiment with German food prices. Agribusiness 22(4), 505-522

Wane, A., Gilbert, S., and Dibooglu, S. (2004). Critical values of the empirical F-distribution for threshold autoregressive and momentum threshold autoregressive models.

Zeng, S., and Gould, B. (2016). Is There Asymmetric Price Transmission in the US Fluid Milk Market? In 2016 Annual Meeting, July 31-August 2, 2016, Boston, Massachusetts (No. 237346). Agricultural and Applied Economics Association. 


\section{Appendix}

\section{Vertical Price Transmission in Swiss Dairy and Cheese Value Chains}

Figure A1: Dairy price development at producer, wholesale and retail level

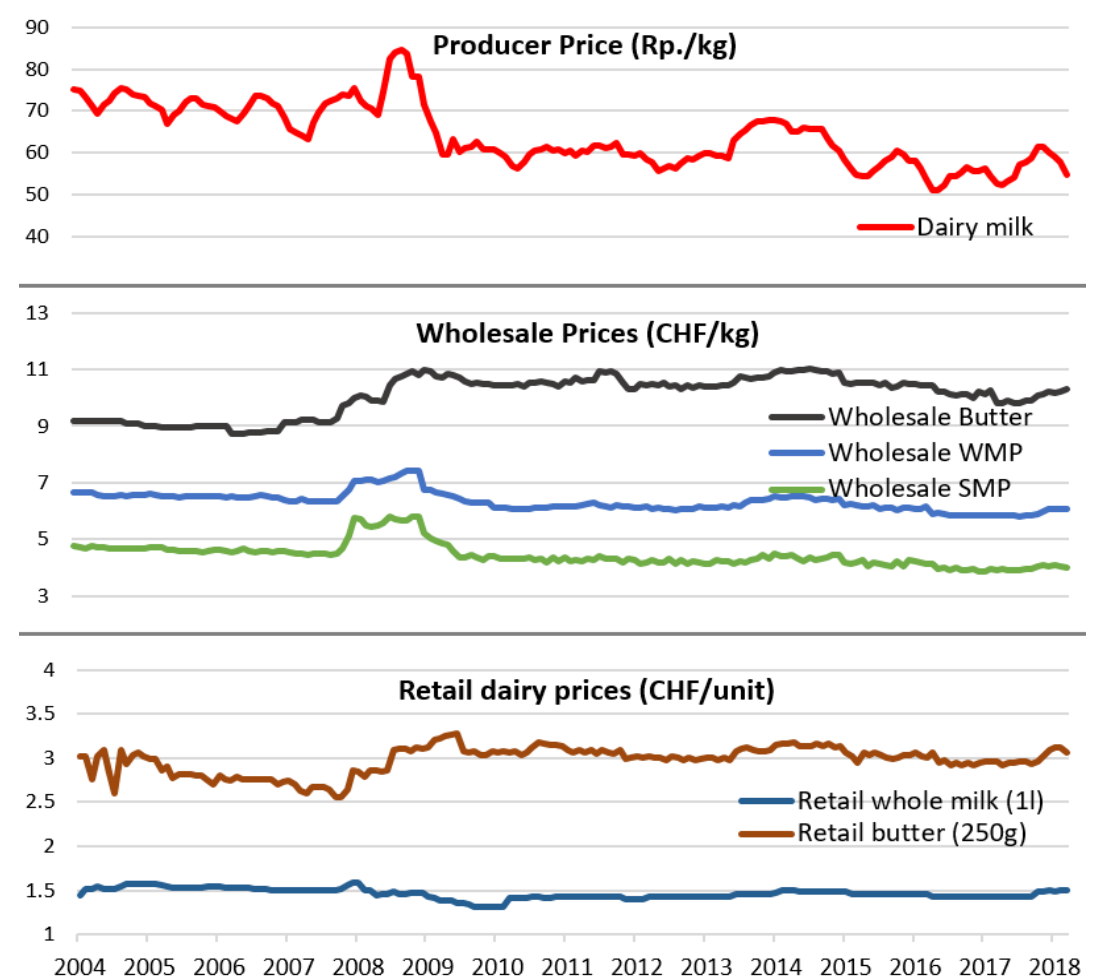

Figure A2: Organic price development at producer, wholesale and retail level
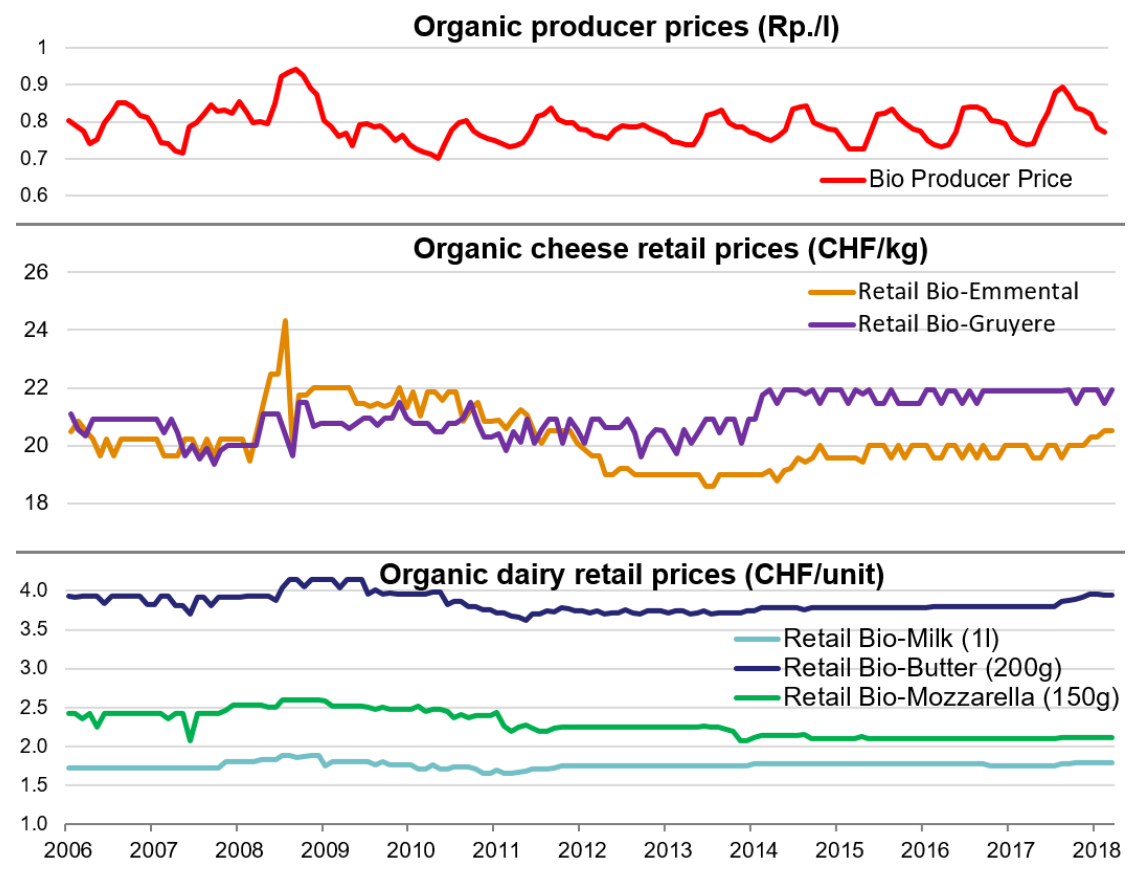
Figure A3: Industrial cheese price development at producer, export and retail level

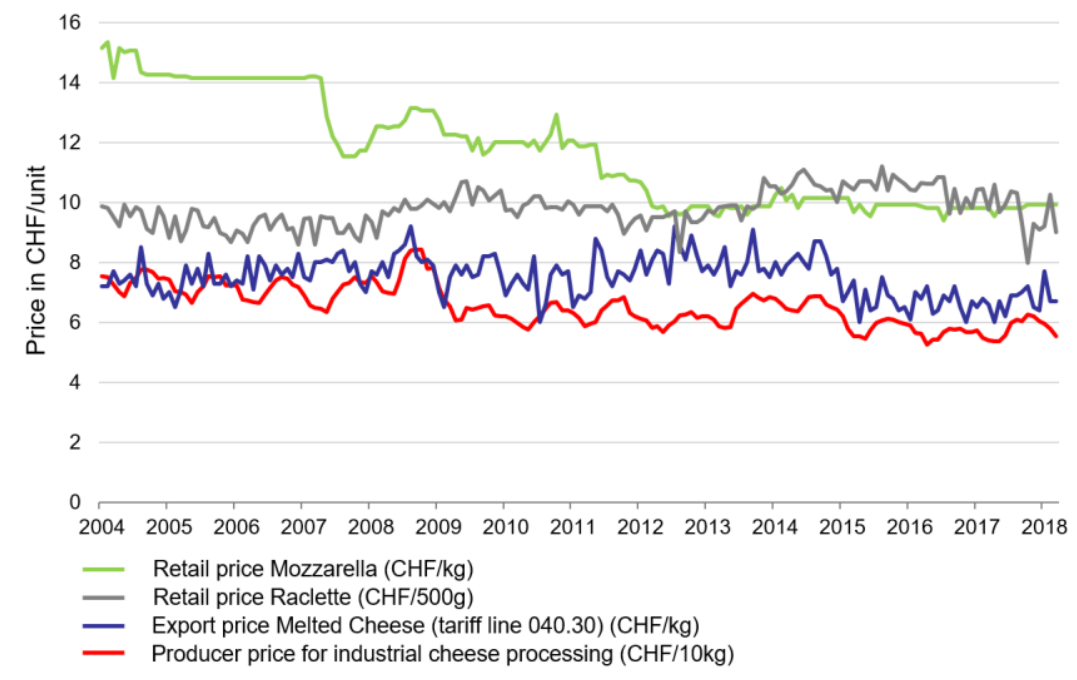

Figure A4: Artisanal cheese price development at producer, export and retail level

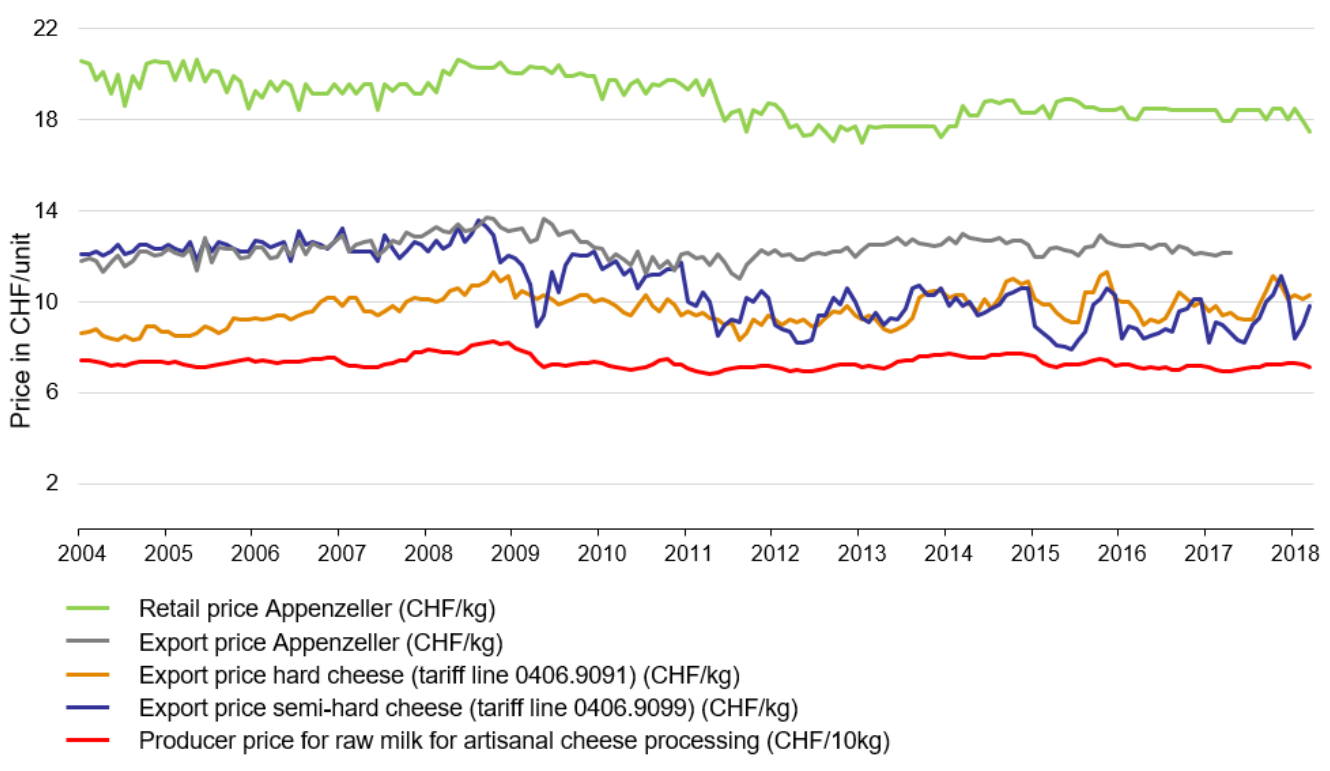

Figure A5: Price development for Gruyère and Emmentaler

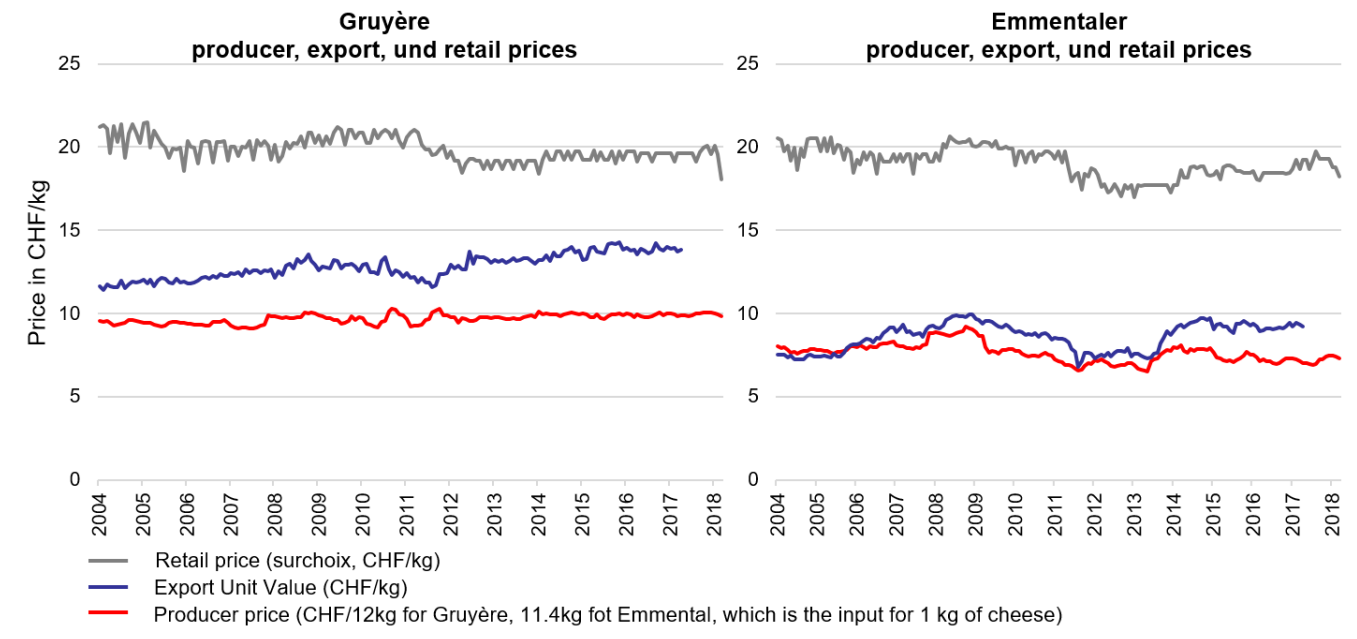


Table A1: Results from unit root and stationarity tests

\begin{tabular}{|c|c|c|c|c|}
\hline & \multirow[t]{2}{*}{$\begin{array}{l}\text { Lags } \\
\text { (AIC) }\end{array}$} & \multirow{2}{*}{$\begin{array}{c}\text { ADF test } \\
\mathrm{H}_{0}: \mathrm{I}(1)\end{array}$} & \multirow{2}{*}{$\begin{array}{c}\text { KPSS test } \\
\mathrm{H}_{0}: \mathrm{I}(0)\end{array}$} & \multirow{2}{*}{$\begin{array}{c}\begin{array}{c}\text { Whittle esti- } \\
\text { mator }\end{array} \\
{[99 \% \text { range }]}\end{array}$} \\
\hline & & & & \\
\hline \multicolumn{5}{|c|}{ Raw milk prices } \\
\hline P_dai & 8 & -1.15 (n.s.) & $1.36^{* * *}$ & \\
\hline P_che_art & 9 & -0.25 (n.s.) & 0.20 (n.s.) & {$[0.86 ; 1.11]$} \\
\hline P_emm & 7 & -0.43 (n.s.) & $0.91 * * *$ & \\
\hline P_gru & 8 & 0.44 (n.s.) & $1.39 * * *$ & \\
\hline P_che_ind & 9 & -1.37 (n.s.) & $1.33 * * *$ & \\
\hline P_org & 10 & 0.01 (n.s.) & $0.44 *$ & {$[0.85 ; 1.12]$} \\
\hline \multicolumn{5}{|l|}{ Export prices } \\
\hline E_hard & 10 & 0.94(n.s.) & $0.36^{*}$ & {$[0.86 ; 1.13]$} \\
\hline E_semi & 9 & -1.17 (n.s.) & $1.55^{* * *}$ & \\
\hline E_emm & 1 & 0.54 (n.s.) & $1.30 * * *$ & \\
\hline E_gru & 5 & 1.17 (n.s.) & $2.06^{* * *}$ & \\
\hline E_melt & 7 & -0.53 (n.s.) & $0.59 * *$ & \\
\hline \multicolumn{5}{|c|}{ Wholesale prices } \\
\hline W_but & 1 & 0.62 (n.s.) & $4.63 * * *$ & \\
\hline W_wmp & 3 & -0.52 (n.s.) & $2.01 * * *$ & \\
\hline W_smp & 1 & -0.60 (n.s.) & $4.07 * * *$ & \\
\hline \multicolumn{5}{|l|}{ Retail prices } \\
\hline R_milk & 4 & $-0.16($ n.s. $)$ & $1.02 * * *$ & \\
\hline R_but & 1 & -0.05 (n.s.) & $2.52 * * *$ & \\
\hline R_emm & 3 & -0.57 (n.s.) & $2.1 * * *$ & \\
\hline R_gru & 4 & -0.78 (n.s.) & $1.58 * * *$ & \\
\hline R_app & 3 & $-0.82($ n.s. $)$ & $2.65 * * *$ & \\
\hline R_mozz & 1 & $-1.86(\mathrm{n} . \mathrm{s})$. & $7.82 * * *$ & \\
\hline R_racl & 7 & -0.31 (n.s.) & $0.94 * * *$ & \\
\hline R_milk_org & 10 & 0.28 (n.s.) & 0.13 (n.s.) & {$[0.84 ; 1.15]$} \\
\hline R_but_org & 3 & 0.02 (n.s.) & $1.27 * * *$ & \\
\hline R_emm_org & 6 & 0.10 (n.s.) & $0.78^{* * *}$ & \\
\hline R_gru_org & 4 & 0.46 (n.s.) & $1.82 * * *$ & \\
\hline R_mozz_org & 3 & -1.01 (n.s.) & $3.18^{* * *}$ & \\
\hline
\end{tabular}

$* / * * / * * *$ : null hypothesis is rejected at $10 \% / 5 \% / 1 \%$ significance level, (n.s.) $=$ not significant at $10 \%$ level. For both tests, deterministic trends are restricted to zero.

Table A2: Results from pairwise Johansen cointegration test

\begin{tabular}{|c|c|c|c|c|}
\hline \multirow[t]{2}{*}{ Tested variable pair } & \multicolumn{2}{|c|}{ Trace test } & \multicolumn{2}{|c|}{ Eigenvalue test } \\
\hline & $\mathrm{H} 0: \mathrm{r}=0$ & $\mathrm{H}_{0}: \mathrm{r} \leq 1$ & $\mathrm{H}_{0}: \mathrm{r}=0$ & $\mathrm{H}_{0}: \mathrm{r}=1$ \\
\hline \multicolumn{5}{|l|}{ Dairy chain } \\
\hline W_but & 15.42 & 2.58 & 12.84 & 2.58 \\
\hline
\end{tabular}




\begin{tabular}{|c|c|c|c|c|c|}
\hline P_dai & W_smp & 13.82 & 4.09 & 9.73 & 4.09 \\
\hline P_dai & W_wmp & 16.77 & 5.36 & 11.43 & 5.36 \\
\hline P_dai & R_milk & 12.49 & 5.28 & 7.22 & 5.28 \\
\hline P_dai & R_but & 11.54 & 4.77 & 6.77 & 4.77 \\
\hline W_but & R_but & $25.51 * * *$ & 2.26 & $21.57 * * *$ & 3.94 \\
\hline \multicolumn{6}{|c|}{ Cheese Chain } \\
\hline P_che_ind & R_mozz & 12.42 & 3.42 & 8.99 & 3.42 \\
\hline P_che_ind & R_racl & 14.67 & 1.91 & 12.76 & 1.91 \\
\hline$P \_$che_ind & E_melt & 17.69 & 3.96 & 12.39 & 3.96 \\
\hline P_che_art & E_hard & 17.73 & 4.61 & 13.11 & 4.61 \\
\hline P_che_art & E_semi & 9.78 & 3.46 & 6.33 & 3.46 \\
\hline P_che_art & R_app & 15.66 & 4.28 & 11.38 & 4.28 \\
\hline E_semi & R_app & 13.08 & 2.47 & 10.60 & 2.47 \\
\hline P_emm & E_emm & 11.62 & 4.54 & 7.07 & 4.54 \\
\hline P_emm & R_emm & 16.03 & 2.76 & 13.26 & 2.76 \\
\hline E_emm & R_emm & 9.20 & 3.53 & 5.66 & 3.53 \\
\hline P_gru & E_gru & $21.03 * *$ & 3.40 & $17.63 * *$ & 3.40 \\
\hline P_gru & R_gru & $18.85^{*}$ & 4.03 & $14.82 *$ & 4.03 \\
\hline E_gru & R_gru & $19.07 *$ & 3.45 & $15.62 *$ & 3.45 \\
\hline \multicolumn{6}{|c|}{ Organic chain } \\
\hline P_org & R_milk_org & $18.78^{*}$ & 5.66 & 13.12 & 5.66 \\
\hline P_org & R_but_org & $28.75 * * *$ & 6.43 & $20.32 * *$ & 6.43 \\
\hline P_org & R_emm_org & 12.37 & 4.87 & 7.50 & 4.87 \\
\hline P_org & R_gru_org & 14.71 & 4.53 & 10.18 & 4.53 \\
\hline P_org & R_mozz_org & 13.10 & 1.67 & 11.43 & 1.67 \\
\hline
\end{tabular}

$* / * * / * * *$ represent $10 / 5 / 1 \%$ significance level ; r= rank, lag length acc. to Schwarz criterion, incl. constant in cointegration, Exog. variables: monthly seasonal dummies

Table A3: Threshold cointegration test results for TAR and MTAR models with threshold $=0$

\begin{tabular}{|c|c|c|c|c|c|c|c|c|c|c|c|c|}
\hline \multirow{3}{*}{$\begin{array}{l}\text { Dairy line } \\
\text { CI-Vector } \\
\text { model }\end{array}$} & \multicolumn{2}{|c|}{$\begin{array}{l}\text { P_dai - } \\
\text { W_but }\end{array}$} & \multicolumn{2}{|c|}{$\begin{array}{l}\text { P_dai - } \\
\text { W_smp }\end{array}$} & \multicolumn{2}{|c|}{$\begin{array}{l}\text { P_dai - } \\
\text { W_wmp }\end{array}$} & \multicolumn{2}{|c|}{$\begin{array}{l}\text { P_dai - } \\
\text { R_milk }\end{array}$} & \multicolumn{2}{|c|}{$\begin{array}{c}\text { P_dai - } \\
\text { R_but }\end{array}$} & \multicolumn{2}{|c|}{$\begin{array}{c}\text { W_but - } \\
\text { R_but }\end{array}$} \\
\hline & $\mathrm{p}_{2}+0.2$ & $29 p_{1-3.50}$ & $\mathrm{p}_{2}-0.66$ & $\mathrm{p}_{1}+1.24$ & $\mathrm{p}_{2}-0.4$ & $0 p_{1}-0.17$ & $\mathrm{p}_{2}-0.2 \mathrm{C}$ & $0 \mathrm{p}_{1}+0.45$ & $\mathrm{p}_{2}+0.1$ & $5 p_{1}-1.70$ & $\mathrm{p}_{2}-0.5 \mathrm{~S}$ & $\mathrm{p}_{1}+0.27$ \\
\hline & $\operatorname{tar}$ & mtar & $\operatorname{tar}$ & mtar & tar & mtar & $\operatorname{tar}$ & mtar & $\operatorname{tar}$ & mtar & $\operatorname{tar}$ & mtar \\
\hline lags (k) & 1 & 1 & 12 & 12 & 12 & 12 & 1 & 1 & 1 & 1 & 1 & 1 \\
\hline$\rho_{1}(+)$ & $-0.05 *$ & -0.01 & $-0.10 *$ & $-0.15^{* *}$ & $-0.15^{* *}$ & $-0.17 * * *$ & -0.07 & $-0.08^{* *}$ & -0.10 & $-0.13^{* *}$ & $-0.25^{* * *}$ & $-0.32 * * *$ \\
\hline$\rho_{2}(-)$ & -0.03 & $-0.06^{* *}$ & $-0.19^{* *}$ & -0.10 & $-0.15^{* *}$ & $-0.12 *$ & $-0.07 * *$ & -0.05 & $-0.13^{* *}$ & $-0.11 *$ & $-0.28 * * *$ & $-0.21 * * *$ \\
\hline $\mathrm{H}_{01}$ : no CI & 2.36 & 3.13 & 3.86 & 3.33 & 3.99 & 4.17 & 2.83 & 2.96 & 4.36 & 4.26 & $10.11 * * *$ & $10.63^{* * *}$ \\
\hline $\mathrm{H}_{02}$ : no aPT & 0.34 & 1.83 & 1.35 & 0.34 & 0.00 & 0.35 & 0.00 & 0.26 & 0.22 & 0.04 & 0.06 & 0.98 \\
\hline
\end{tabular}




\begin{tabular}{|c|c|c|c|c|c|c|c|c|c|c|c|c|}
\hline \multirow{3}{*}{$\begin{array}{l}\text { Cheese line } \\
\text { CI-Vector } \\
\text { model }\end{array}$} & \multicolumn{2}{|c|}{$\begin{array}{c}\text { P_che_ind - } \\
\text { R_mozz }\end{array}$} & \multicolumn{2}{|c|}{$\begin{array}{c}P_{-} \text {che_ind - } \\
R_{-} \text {racl }\end{array}$} & \multicolumn{2}{|c|}{$\begin{array}{c}\text { P_che_ind - } \\
\text { E_melt }\end{array}$} & \multicolumn{2}{|c|}{$\begin{array}{c}\text { P_che_art - } \\
\text { E_hard }\end{array}$} & \multicolumn{2}{|c|}{$\begin{array}{c}\text { P_che_art - } \\
\text { E_semi }\end{array}$} & \multicolumn{2}{|c|}{$\begin{array}{c}\text { P_che_art - } \\
\text { R_app }\end{array}$} \\
\hline & $\mathrm{p}_{2}-1.0$ & $5 p_{1}+3.85$ & $\mathrm{p}_{2}+0.24$ & $4 p_{1-3.95}$ & $\mathrm{p}_{2}-0$. & $37 p_{1-0.46}$ & $\mathrm{p}_{2}-1.0$ & $1 p_{1}+2.06$ & $\mathrm{p}_{2}-1$ & $4 \mathrm{p}_{1}+5.55$ & $\mathrm{p}_{2}-0$. & $2 p_{1}-1.13$ \\
\hline & $\operatorname{tar}$ & mtar & tar & mtar & $\operatorname{tar}$ & mtar & $\operatorname{tar}$ & mtar & $\operatorname{tar}$ & mtar & $\operatorname{tar}$ & mtar \\
\hline lags (k) & 12 & 12 & 2 & 2 & 10 & 10 & 10 & 10 & 12 & 12 & 2 & 3 \\
\hline$\rho_{1}(+)$ & $-0.08 * *$ & -0.02 & -0.14 & -0.12 & -0.18 & -0.15 & -0.06 & $-0.15^{* *}$ & -0.06 & -0.08 & $-0.12^{* *}$ & $-0.14 * *$ \\
\hline$\rho_{2}(-)$ & -0.05 & $-0.14 * * *$ & $-0.24 * * *$ & $-0.22 * *$ & $*-0.22 *$ & $-0.24 * *$ & $-0.16^{* *}$ & -0.06 & -0.05 & -0.03 & -0.04 & -0.04 \\
\hline $\mathrm{H}_{01}$ : no CI & 2.82 & 5.83 & 4.28 & 4.25 & 1.92 & 2.15 & 2.43 & 2.45 & 1.11 & 1.37 & 2.52 & 3.20 \\
\hline $\mathrm{H}_{02}:$ no aPT & 0.39 & $6.20 * *$ & 0.78 & 0.72 & 0.08 & 0.52 & 0.99 & 1.03 & 0.02 & 0.54 & 1.11 & 1.83 \\
\hline
\end{tabular}

\begin{tabular}{|c|c|c|c|c|c|c|c|c|c|c|c|c|}
\hline $\begin{array}{l}\text { AOP cheese } \\
\text { line }\end{array}$ & \multicolumn{2}{|c|}{$\begin{array}{l}\text { P_emm - } \\
\text { E_emm }\end{array}$} & \multicolumn{2}{|c|}{$\begin{array}{l}\text { P_emm - } \\
\text { R_emm }\end{array}$} & \multicolumn{2}{|c|}{$\begin{array}{c}\text { E_emm - } \\
\text { R_emm }\end{array}$} & \multicolumn{2}{|c|}{$\begin{array}{c}\text { P_gru - } \\
\text { E_gru }\end{array}$} & \multicolumn{2}{|c|}{$\begin{array}{c}\mathrm{P} \_g r u- \\
\text { R_gru }\end{array}$} & \multicolumn{2}{|c|}{$\begin{array}{c}\text { E_gru - } \\
\text { R_gru }\end{array}$} \\
\hline CI-Vector & $\mathrm{p}_{2}-0.4$ & $0 \mathrm{p}_{1}-0.96$ & $\mathrm{p}_{2}-0.39$ & $\mathrm{p}_{1}-1.32$ & $\mathrm{p}_{2}-0.1$ & $0 p_{1-2.73}$ & $\mathrm{p}_{2}-1.13$ & $3 \mathrm{p}_{1}+2.41$ & $\mathrm{p}_{2}+0$. & $9 p_{1}-4.69$ & $\mathrm{p}_{2}-0$ & $7 p_{1-3.68}$ \\
\hline model & $\operatorname{tar}$ & mtar & $\operatorname{tar}$ & mtar & $\operatorname{tar}$ & mtar & $\operatorname{tar}$ & mtar & $\operatorname{tar}$ & mtar & tar & mtar \\
\hline lags (k) & 1 & 1 & 1 & 3 & 2 & 2 & 1 & 1 & 3 & 3 & 3 & 3 \\
\hline$\rho_{1}(+)$ & -0.02 & -0.04 & $-0.19^{* * *}$ & $-0.20 * *$ & *-0.11** & -0.07 & $-0.17 * *$ & $-0.25 * * *$ & -0.13 & -0.11 & -0.15 & -0.10 \\
\hline$\rho_{2}(-)$ & $-0.05 *$ & -0.05 & $-0.12 *$ & $-0.12 *$ & -0.04 & -0.08 & $-0.15^{* *}$ & -0.07 & $-0.17 *$ & $-0.19^{* *}$ & $-0.18^{*}$ & $-0.23^{* *}$ \\
\hline $\mathrm{H}_{01}:$ no CI & 1.88 & 1.67 & 5.05 & 5.20 & 2.48 & 1.91 & 5.89 & $8.24 * *$ & 2.40 & 2.60 & 2.40 & 2.94 \\
\hline $\mathrm{H}_{02}:$ no aPT & 0.46 & 0.04 & 0.46 & 0.85 & 1.13 & 0.00 & 0.10 & $4.47^{* *}$ & 0.15 & 0.55 & 0.05 & 1.09 \\
\hline
\end{tabular}

\begin{tabular}{|c|c|c|c|c|c|c|c|c|c|c|}
\hline \multirow{3}{*}{$\begin{array}{l}\text { Organic line } \\
\text { CI-Vector } \\
\text { model }\end{array}$} & \multicolumn{2}{|c|}{$\begin{array}{c}\text { P_org - } \\
\text { R_milk_org }\end{array}$} & \multicolumn{2}{|c|}{$\begin{array}{c}\text { P_org - } \\
\text { R_but_org }\end{array}$} & \multicolumn{2}{|c|}{$\begin{array}{c}\text { P_org - } \\
\text { R_emm_org }\end{array}$} & \multicolumn{2}{|c|}{$\begin{array}{c}\text { P_org - } \\
\text { R_gru_org }\end{array}$} & \multicolumn{2}{|c|}{$\begin{array}{c}\text { P_org - } \\
\text { R_mozz_org }\end{array}$} \\
\hline & \multicolumn{2}{|c|}{$\mathrm{p}_{2}-0.19 \mathrm{p}_{1}+0.25$} & \multicolumn{2}{|c|}{$\mathrm{p}_{2}-0.16 \mathrm{p}_{1}-0.63$} & \multicolumn{2}{|c|}{$\mathrm{p}_{2}-0.10 \mathrm{p}_{1}-2.58$} & \multicolumn{2}{|c|}{$\mathrm{p}_{2}-0.03 \mathrm{p}_{1}-2.91$} & \multicolumn{2}{|c|}{$\mathrm{p}_{2}-0.18 \mathrm{p}_{1}-0.02$} \\
\hline & $\operatorname{tar}$ & mtar & $\operatorname{tar}$ & mtar & $\operatorname{tar}$ & mtar & $\operatorname{tar}$ & mtar & $\operatorname{tar}$ & mtar \\
\hline lags $(\mathrm{k})$ & 12 & 12 & 12 & 12 & 5 & 5 & 3 & 3 & 2 & 2 \\
\hline$\rho_{1}(+)$ & $-0.16^{* *}$ & $-0.20 * * *$ & -0.06 & -0.01 & -0.06 & -0.08 & -0.02 & -0.04 & -0.04 & $-0.07 * *$ \\
\hline$\rho_{2}(-)$ & $-0.17 * *$ & -0.11 & $-0.11 *$ & $-0.20 * * *$ & *-0.04 & -0.01 & $-0.14 *$ & $-0.12 *$ & -0.00 & 0.04 \\
\hline $\mathrm{H}_{01}$ : no CI & 3.82 & 4.26 & 1.84 & 4.77 & 0.81 & 1.22 & 1.91 & 1.51 & 0.66 & 2.56 \\
\hline $\mathrm{H}_{02}:$ no aPT & 0.02 & 0.83 & 0.36 & $6.07 * *$ & 0.08 & 0.87 & 1.46 & 0.67 & 0.51 & $4.30 * *$ \\
\hline
\end{tabular}

$* / * * / * * *$ represent significance at $10 \% / 5 \% / 1 \%$ level

$\mathrm{CI}=$ Cointegration; $(\mathrm{M}) \mathrm{TAR}=($ Momentum $)$ Threshold Autoregressive Model;

$\mathrm{H}_{01}$ : no cointegration ( $\rho_{1}=\rho_{2}=0$; $\Phi$-test, with critical values from Wane et al. 2004, assuming 150 observations).

$\mathrm{H}_{02}$ : no asymmetric adjustment $(\rho 1=\rho 2$; F-test). Lag length selected by minimizing AIC.

Table A4: Results from Hansen and Seo Threshold Cointegration Test

Tested variable pair

Hansen ad Seo (2002)

$\mathrm{H}_{0}$ : Linear Coint. $\mathrm{H}_{\mathrm{A}}$ : Threshold Coint.

\begin{tabular}{llcccr}
\hline Dairy chain & & lag & Test stat. & p-value & Threshold value \\
\hline P_dai & W_but & 2 & 21.00 & 0.17 & 6.14 \\
P_dai & W_smp & 2 & 17.93 & 0.58 & 2.54 \\
P_dai & W_wmp & 2 & 18.30 & 0.38 & 0.52 \\
P_dai & R_milk & 2 & 16.59 & 0.60 & 3.32 \\
P_dai & R_but & 2 & 14.05 & 0.89 & 6.08 \\
W_but & R_but & 2 & 14.68 & 0.82 & 0.38 \\
\hline
\end{tabular}




\begin{tabular}{llllll}
\hline Cheese Chain & & & & & \\
\hline P_che_ind & R_mozz & 9 & 46.32 & 0.49 & 3.77 \\
P_che_ind & R_racl & 9 & 46.41 & 0.60 & 9.48 \\
P_che_ind & E_melt & 9 & 49.07 & 0.35 & 0.55 \\
P_che_art & E_hard & 2 & 12.90 & 0.97 & 6.05 \\
P_che_art & E_semi & 2 & 14.82 & 0.72 & 4.39 \\
P_che_art & R_app & 3 & 24.29 & 0.36 & 3.18 \\
P_emm & E_emm & 2 & 14.10 & 0.86 & 3.85 \\
P_emm & R_emm & 3 & 25.91 & 0.12 & 0.02 \\
E_emm & R_emm & 3 & 21.37 & 0.65 & -0.03 \\
P_gru & E_gru & 7 & 35.52 & 0.78 & 3.37 \\
P_gru & R_gru & 7 & 32.48 & 0.95 & 6.26 \\
E_gru & R_gru & 4 & 28.22 & 0.32 & 8.12 \\
\hline Organic chain & & & & \\
\hline P_org & R_milk_org & 9 & 50.18 & 0.22 \\
P_org & R_but_org & 9 & 50.59 & 0.23 & 6.21 \\
P_org & R_emm_org & 9 & 49.76 & 0.27 & 3.66 \\
P_org & R_gru_org & 9 & 57.45 & 0.08 & 4.98 \\
P_org & R_mozz_org & 9 & 48.89 & 0.36 & 5.97 \\
\hline
\end{tabular}

Note: lag length acc. to AIC criterion, incl. constant in cointegration, 100 bootstraps, all prices in logarithms, threshold restriction: min. $10 \%$ of observation within one regime, no seasonal dummies included

Table A5: Testing for asymmetric error correction in linear VECM models (based on Johansen cointegration)

\begin{tabular}{|c|c|c|c|c|c|c|c|c|}
\hline \multicolumn{3}{|c|}{ Tested variable pair } & \multicolumn{2}{|c|}{ p1 } & \multicolumn{2}{|c|}{ p2 } & \multicolumn{2}{|c|}{ Symm. test } \\
\hline $\mathrm{p} 1$ & $\mathrm{p} 2$ & lags & $\alpha^{+}$ & $\alpha^{-}$ & $\alpha^{+}$ & $\alpha^{-}$ & $\begin{array}{c}\mathrm{p} 1 \\
\left(\alpha^{+}=\alpha^{-}\right)\end{array}$ & $\begin{array}{c}\mathrm{p} 2 \\
\left(\alpha^{+}=\alpha^{-}\right)\end{array}$ \\
\hline
\end{tabular}

Dairy chain

\begin{tabular}{|c|c|}
\hline p1 & $\mathrm{p} 2$ \\
\hline P_dai & W_but \\
\hline P_dai & W_smp \\
\hline P_dai & W_wmp \\
\hline P_dai & $\mathrm{R}$ _milk \\
\hline
\end{tabular}

\begin{tabular}{lll}
4 & $-0.04^{* *}$ & -0.03 (n.s.) \\
4 & $-0.05($ n.s.) & -0.03 (n.s.) \\
4 & $0.01($ n.s.) & 0.02 (n.s.) \\
4 & $-0.05^{* *}$ & $-0.03 * *$ \\
\hline
\end{tabular}

$0.02 * *$
$0.08 *$
$0.09 * * *$
0.00 (n.s.)

0.02 (n.s.)

(n.s.)

(n.s.)

Cheese chain

$\begin{array}{ll}\frac{\mathrm{p} 1}{\mathrm{P} 2} & \frac{\mathrm{p} 2}{\mathrm{P} \_ \text {gru }} \\ \text { E_gru } \\ \text { E_gru } & \text { R_gru }\end{array}$

4

$-0.17 * * *$

$-0.15 * * *$

-0.09 (n.s.)

0.08 (n.s.)

(n.s.)

(n.s.)

Organic chain

$\frac{\mathrm{p} 1}{\text { P_org }} \frac{\mathrm{p} 2}{\text { R_milk_org }}$

$4 \quad-0.07$ (n.s.)

$-0.10 * * *$

-0.05 (n.s.)

0.01 (n.s.)

(n.s.)

(n.s.)

\begin{tabular}{lllll} 
P_org R_but_org & 2 & -0.07 (n.s.) & -0.01 (n.s.) & $0.12 * * *$ \\
\hline
\end{tabular}

$* / * * / * * *$ represent $10 / 5 / 1 \%$ significance level; (n.s.) $=$ not significant at $10 \%$ level

Model with prices in logarithms, incl. 11 seasonal dummies, lag selection according to Schwarz criterion.

Note: model not chosen because no significant asymmetries were detected. 
Table A6: VAR models short-term asymmetry test

\begin{tabular}{|c|c|c|c|}
\hline \multicolumn{2}{|c|}{ Tested variable pair } & \multicolumn{2}{|c|}{ Cum. lag asymmetry } \\
\hline $\mathrm{p} 1$ & $\mathrm{p} 2$ & $\begin{array}{l}\mathrm{p} 1 \rightarrow \mathrm{p} 2 \\
\left(\mathrm{H}_{05}\right)\end{array}$ & $\begin{array}{l}\mathrm{p} 2 \rightarrow \mathrm{p} 1 \\
\left(\mathrm{H}_{06}\right)\end{array}$ \\
\hline \multicolumn{4}{|c|}{ Dairy chain } \\
\hline$P_{-}$dai & W_but & (n.s.) & (n.s.) \\
\hline P_dai & W_smp & (n.s.) & (n.s.) \\
\hline P_dai & W_wmp & (n.s.) & (n.s.) \\
\hline$P_{-}$dai & R_milk & $*$ & (n.s.) \\
\hline$\underline{P}$ _dai & R_but & (n.s.) & (n.s.) \\
\hline \multicolumn{4}{|c|}{ Cheese Chain } \\
\hline P_che_ind & R_mozz & (n.s.) & (n.s.) \\
\hline P_che_ind & R_racl & (n.s.) & (n.s.) \\
\hline P_che_ind & E_melt & (n.s.) & (n.s.) \\
\hline P_che_art & E_hard & (n.s.) & (n.s.) \\
\hline P_che_art & E_semi & (n.s.) & (n.s.) \\
\hline P_che_art & R_app & (n.s.) & $*$ \\
\hline $\mathrm{P} \_$emm & E_emm & (n.s.) & (n.s.) \\
\hline $\mathrm{P} \_$emm & R_emm & (n.s.) & (n.s.) \\
\hline E_emm & R_emm & (n.s.) & (n.s.) \\
\hline \multicolumn{4}{|c|}{ Organic chain } \\
\hline P_org & R_milk_org & (n.s.) & (n.s.) \\
\hline$P_{-}$org & R_but_org & $*$ & (n.s.) \\
\hline$P_{-}$org & R_emm_org & (n.s.) & (n.s.) \\
\hline P_org & R_gru_org & (n.s.) & (n.s.) \\
\hline $\mathrm{P}_{-}$org & R_mozz_org & (n.s.) & (n.s.) \\
\hline
\end{tabular}




\title{
IV Market Integration and Market Efficiency under Seasonal Tariff Rate Quotas
}

Author: Judith Hillen

Published in Journal of Agricultural Economics (Vol. 70, No. 3, 2019, 859-873)

\begin{abstract}
Switzerland applies seasonal tariff rate quotas (TRQs) for the import of many fruits and vegetables during the domestic harvest season. We examine how this system affects the relationship between Italian and Swiss tomato prices and test for physical market integration and spatial equilibrium conditions over time. We use detailed, transaction-based data on trade flows and trade costs and estimate an extended parity bounds model, following Barrett and Li (2002). We confirm that in the summer season, when TRQs are in place, markets are inefficient. While quota holders receive positive rents, the marginal rents for importers without quota shares are negative. This inhibits trade flows above the in-quota import quantity allowed by TRQs. Hence, despite leading to inefficiencies and creating rents for importers, seasonal TRQs are effective in protecting domestic production against competing imports.
\end{abstract}

Keywords: parity bounds model, Switzerland, tariff rate quotas, tomato trade 


\section{Introduction}

Tariff rate quotas (TRQs) are two-level tariffs with a low 'in-quota' tariff for imports up to a defined quota volume and a higher 'out-of-quota' tariff charged for all subsequent imports. As a result of the tariffication efforts in the Uruguay Round of the General Agreement on Trade and Tariffs, TRQs were adopted for products previously subject to non-tariff measures, such as pure import quotas. Since then, they have been a widely used instrument to control market access and are still applied in more than 40 countries, particularly for politically sensitive agricultural products (Beckman et al. 2017, WTO 2018). Non-seasonal TRQs have received considerable research attention, and their mechanisms and economic effects have been studied extensively (e.g. Boughner et al. 2000, Skully 2001, de Gorter and Kliauga 2006).

Ever since TRQs were first introduced, economists have heavily criticized the instrument (e.g. Abbott and Paarlberg 1998, Gibson et al. 2001, Abbott 2002). This criticism has addressed the non-tariff barrier effects that TRQs cause, their complex effects on price stability, the quota rents that they generate, and the fact that quota allocation is often non-transparent. Abbott and Paarlberg (1998) find that TRQs either mimic pure quotas or function like pure tariffs, depending on import quantities and how the tariffs and quota volume are set. Switches between these two states can occur, so that the mechanism is not always predictable and the effect on price stability is uncertain. Moreover, Gibson et al. (2001) state that often 'mega-tariffs' (>100\%) and highly complex tariff line regulations apply, which is contrary to the original TRQ principles of market access and clear tariffication. Finally, it has been shown conceptually and empirically that quota-holding importers can capture rents (Skully 2001, Abbott 2002). Therefore, quota allocation mechanisms are critical, especially if they are non-transparent or discriminatory, as is the case with 'first-come, first served' or historical allocation (Skully 2001, de Gorter and Kliauga 2006).

Less research attention has been dedicated to seasonal TRQs, which are only effective during domestic supply seasons. Such TRQs are mostly applied for fruit and vegetables, with the aim of protecting domestic production from competing imports in season, while allowing a cheap import supply out of season (de Gorter and Kliauga 2006). Currently, the European Union, Iceland, Norway, South Korea and Switzerland apply seasonal TRQs for several perishable fresh fruit and vegetable products (WTO 2018). The analysis of seasonal TRQs is made more complicated by the fact that they often do not have fixed yearly quota volumes; instead, the yearly quota volume is adjusted depending on market conditions (e.g. the size of the domestic harvest). 
Given their wide application and the lack of previous empirical studies, we analyse how this policy instrument affects market integration and market efficiency using the example of Swiss tomato imports. Using an extended parity bounds model (PBM) and detailed customs data on trade flows, tariff costs and prices, we study how seasonal TRQs applied by Switzerland affect Italian-Swiss tomato trade, market integration and rents throughout the year. Section 2 outlines the setting and the framework of our analysis. Section 3 explains our data and methods, while section 4 presents our results. Section 5 concludes.

\section{Setting}

Switzerland has a long history of strong border protection for agricultural products. Following the Uruguay Round, TRQs replaced the previous instrument of import quotas (Swiss Federal Council 1994). The TRQ system for tomatoes is seasonal, as it is for many domestically grown fruits and vegetables. Figure 1 schematically illustrates how this TRQ functions. ${ }^{14}$ During the Swiss tomato season, when domestically produced tomatoes are available, the system aims to protect domestic production from cheaper import competition. The official policy goals are to (a) support farm income by keeping domestic producer prices high, and (b) to ensure domestic food supply, as the degree of self-sufficiency is of great concern to Swiss agricultural policy (Loi et al. 2016, Ferjani et al. 2018). Outside the Swiss tomato season, the system is designed to ensure sufficient supply through imports. The average weekly import volumes for Italian round tomatoes in figure 1 show that indeed, only low quantities are imported during the summer month, and larger volumes of up to 100 tons per week out of season, during winter and spring.

More specifically, from 21 October until 30 April, unlimited tomato imports are allowed at a low in-quota tariff of $0.05 \mathrm{CHF} / \mathrm{kg}$ or even $0.00 \mathrm{CHF} / \mathrm{kg} .{ }^{15}$ During this time, there is no competition with domestic products, and the quota is not effective ('non-administered period'). If the Swiss tomato harvest starts later than 1 May or ends before 20 October, the Swiss Federal Office for Agriculture (FOAG) can prolong the non-administered period. This usually happens in May and early October and can vary from year to year.

${ }^{14}$ For a detailed explanation of the Swiss TRQ system and references to the specific legal texts, see Loi et al. (2016).

15 For imports from EU and European Free Trade Association (EFTA) trade partners there is an additional agreement about duty-free imports. This is limited to 10,000 tons net for all types of tomatoes (TRQ number 106) and is only applicable in the non-managed period (Swiss Federal Council 2008). Above this quantity, the inquota tariff of $0.05 \mathrm{CHF} / \mathrm{kg}$ applies. 


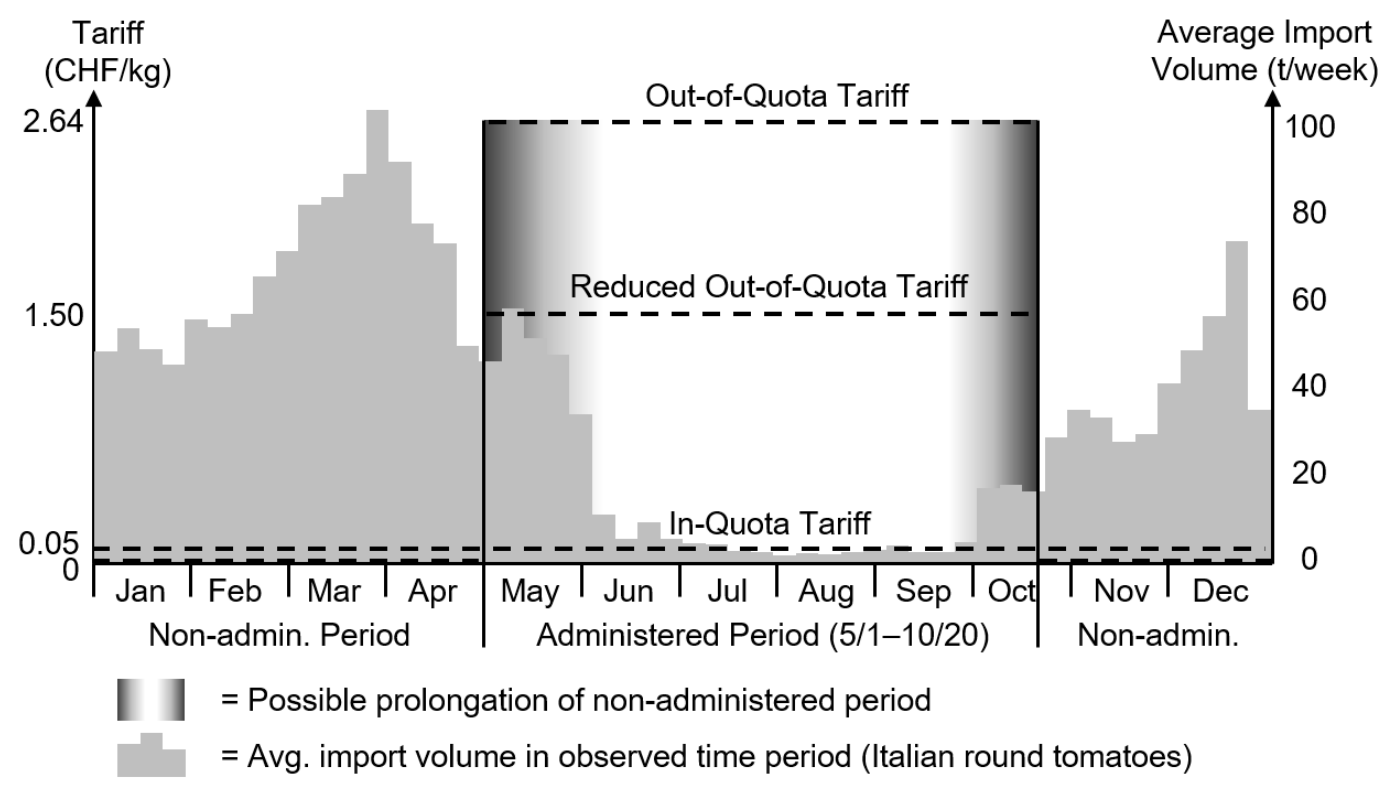

Figure 1: Applicable tariff rates and import volumes of tomato imports from the EU

In the administered period, there are in-quota and out-of-quota tariffs. There are limited quotas for imports at the low in-quota tariff of $0.05 \mathrm{CHF} / \mathrm{kg}$, which is equivalent to $1.4 \%$ of the average Swiss retail price. Requests for such quotas are discussed and agreed upon on a weekly basis by the umbrella organization Swisslegumes, taking into account current domestic production and demand estimates. Producers, importers, traders and retailers are represented in this interbranch organization. They jointly decide whether and what volume of imports is needed and request that FOAG opens a corresponding quota. FOAG then officially releases the quota and allocates quota shares to individual importers. Due to these flexible weekly quota openings, also the annual quota volume can vary from year to year.

Quota allocation is calculated based on an importer's share of the previous year's domestic purchases and imports. Hence, historically large importers get access to large quota shares. Historically smaller importers receive proportionally smaller quota shares, and new entrants into the market receive no access to quota shares in their first year. Generally, importers fully exploit the released quota quantities. Quantities exceeding these quotas can only be imported at a high out-of-quota tariff $(2.64 \mathrm{CHF} / \mathrm{kg}$, equivalent to $73.9 \%$ of the average retail price $)$. If there is full supply through domestic production, or even oversupply, no quotas are released in the respective week, and a reduced out-of-quota tariff $(1.50 \mathrm{CHF} / \mathrm{kg}$, equivalent to $42.0 \%$ of the average retail price) applies to all imports. This reduced rate is a historical compromise without economic justification. 
Even though only relatively low volumes are imported at these high tariff rates in the administered period (see figure 1), they lead to high additional costs for the importers, which are ultimately passed on to Swiss consumers. For tomato imports, these extra tariffs, paid on top of the in-quota tariff of 0.05 CHF per kg add up to 259'414 CHF per year on average (for 2011-2015).

As the yearly quota volume in this Swiss system is flexible and negotiated on a weekly basis, the standard textbook analysis of a TRQ (with a fixed quota volume and four possible excess demand conditions - no trade, quota not binding, quota binding and quota no longer binding see e.g. Skully 2001) does not apply. The specific Swiss TRQ system has been previously analysed by Loi et al. (2016) and Gray et al. (2017). Both studies suspect the system to generate rents that are then captured by the downstream sector, particularly the large retailers. Yet, they do not prove the existence or quantify these rents empirically, which is one of the aims of this study.

\section{Data and Methods}

\subsection{Data}

We combine data on prices, trade costs and trade flows, analysing weekly data from March 2011 until May 2015, as this is the longest timeframe available. We chose the case of Italian tomato imports because in Switzerland tomatoes are the product with the largest volume of trade that is subject to seasonal TRQs, and Italy is a major trade partner for which reliable price data are available. ${ }^{16}$ Table 1 gives an overview of our data.

\section{Price data}

The Swiss domestic tomato season is quite short (from roughly May to September), and domestic producer and wholesale prices are only reported during these months. To construct a continuous domestic Swiss retail price series we use retail prices for ordinary, round, red tomatoes (not cocktail tomatoes, not on the vine, non-organic). For Italy, we use wholesale price data, which is the relevant level for international trade. The comparison of Swiss retail and Italian wholesale prices leads to a permanent measurement difference in price levels. This wholesale-retail marketing margin is considered in the later empirical model.

\footnotetext{
16 The top three countries of origin for Swiss round red tomato imports (not cocktail, on the vine or organic) are Morocco, Spain and Italy. However, only for Italy sufficiently detailed weekly price data are available to conduct this analysis.
} 
Table 1: Description of price and trade data for Swiss-Italian tomato trade

\begin{tabular}{|c|c|c|c|c|c|}
\hline Variable & Unit & Description & Source & mean & sd \\
\hline $\mathrm{P}^{\mathrm{CH}}$ & $\mathrm{CHF} / \mathrm{kg}$ & Swiss retail price & FOAG & 3.57 & 0.41 \\
\hline $\mathrm{P}^{\mathrm{IT}}$ & $\mathrm{CHF} / \mathrm{kg}$ & Italian wholesale price & ISMEA & 1.80 & 0.44 \\
\hline Tariff $^{\text {avg }}$ & $\mathrm{CHF} / \mathrm{kg}$ & $\begin{array}{l}\text { average tariff cost for Italian tomato imports, } \\
\text { weighted by weekly import volume }\end{array}$ & $\mathrm{KIC}$ & 0.38 & 0.59 \\
\hline Tariff & $\mathrm{CHF} / \mathrm{kg}$ & $\begin{array}{l}\text { marginal tariff cost for Italian tomato imports: } \\
\text { highest tariff rate paid in observed week }\end{array}$ & $\mathrm{KIC}$ & 0.80 & 1.06 \\
\hline Trade & $\begin{array}{l}\text { dummy } \\
(0 / 1)\end{array}$ & $\begin{array}{l}\text { dummy variable for observed trade flows of }>5 t \\
\text { per week }\end{array}$ & $\mathrm{KIC}$ & 0.74 & $\mathrm{n} / \mathrm{a}$ \\
\hline
\end{tabular}

Continuous weekly data from March 2011 until May 2015 is used for all variables (220 observations). Mean and standard deviation refer to the whole sample data, including administered and non-administered period.

FOAG $=$ Swiss Federal Office for Agriculture, ISMEA = Italian Service Institute for Agricultural and Food Markets, $\mathrm{KIC}=$ Kontingente Import Controlling $($ by FOAG), sd = standard deviation.

\section{Trade volume data}

We use data on Swiss imports of Italian tomatoes derived from a transaction-based import controlling tool administered by the Swiss customs authorities. We only consider non-organic round tomatoes with a diameter of less than $80 \mathrm{~mm}$ (tariff line 0702.009), excluding tomatoes on the vine and cocktail tomatoes. As the database reports country of origin, import volume, import value, applied tariff rate and total tariffs paid per individual import transaction $i$, we are able to calculate the total import volume from Italy and the associated tariff costs in any given week $t$. In the ensuing empirical analysis, we distinguish between 'trade' and 'no-trade' periods.

\section{Trade cost data}

To correctly represent the complex Swiss TRQ system with its four different tariff rates $(0.00$ or $0.05 \mathrm{CHF} / \mathrm{kg}$ in-quota, and 1.50 or $2.64 \mathrm{CHF} / \mathrm{kg}$ out-of-quota), we distinguish between average and marginal tariffs. The average tariff is the volume-weighted effectively paid tariff rate, which we calculate by weighting the tariff rate applied to an individual import transaction $i$ by this transaction's share in the overall volume of imports in week $t$, and summing over all transactions:

$$
\text { Tariff }_{t}^{a v g}=\frac{\sum_{i}\left(\operatorname{Vol}_{i} * \operatorname{Tariff}_{i}\right)}{\sum_{i} \operatorname{Vol}_{i}} \text { for all transactions } i \text { in week } t
$$

In contrast, the marginal tariff is defined as the highest observed tariff rate that applied to an import transaction in week $t$. This is the tariff rate that any additional importer would pay. As quotas are always filled, in the administered period the marginal tariff rate is de facto the out- 
of-quota tariff (2.56 CHF/kg) or (in weeks without quota openings) the reduced out-of-quota tariff (1.50 CHF/kg):

$$
\text { Tariff }_{t}^{\text {marg }}=\max _{i}\left(\text { Tariff }_{i}\right) \text { for all transactions } i \text { - in week } t \text {. }
$$

Overall trade costs (TC) consist of the variable tariff costs, as calculated above, plus other unknown trade costs, such as transport and marketing costs. We assume that these other costs were constant over time over the duration of our sample (Fixcost):

$$
\begin{aligned}
& T C_{t}^{a v g}=\text { Tariff }_{t}^{a v g}+\text { Fixcost } \\
& T C_{t}^{\text {marg }}=\text { Tariff } f^{\text {marg }}+\text { Fixcost. }
\end{aligned}
$$

We do not estimate or approximate these fixed costs but include them as a constant measurement error in the model, as explained in the following section.

\subsection{Parity Bounds Model}

Our study combines trade and price analysis. Following Barrett (2001) we distinguish between market integration (i.e. physical trade behaviour) and market efficiency between the trade partners (i.e. the relationship between prices, costs and resulting rents). To do so, we apply a parity bounds model (PBM), which was first suggested by Spiller and Huang (1986) and further developed by Baulch (1997) and Park et al. (2002). We use an extended model specification by Barrett and Li (2002), which enables us to combine trade and price data.

The standard PBM defines three different cases or 'regimes', and estimates the probability of observing each of these regimes at a given point in time. In the first case, the spatial price differential between two markets, here Switzerland $(\mathrm{CH})$ and Italy $(I T)$, is equal to trade cost (TC), implying market efficiency with no rents.

$$
P_{t}^{C H}-P_{t}^{I T}=T C_{t}
$$

Alternatively, the price differential can be smaller than the trade cost. In this case, there are no profitable spatial arbitrage opportunities.

$$
P_{t}^{C H}-P_{t}^{I T}<T C_{t}
$$

In the third case, the price differential exceeds trade costs. This implies that spatial arbitrage opportunities are not fully exploited, positive rents exist, and markets are not efficient. 


$$
P_{t}^{C H}-P_{t}^{I T}>T C_{t}
$$

The inefficiency depicted in equation (7) can occur for numerous reasons such as trade restrictions, public price support and non-competitive pricing practices (Baulch 1997, Hranaiova and de Gorter 2005). These equations can also be re-written in terms of rents $R_{t}$, which are equal to, less than or greater than zero for the above three cases, respectively.

$$
R_{t}=P_{t}^{C H}-P_{t}^{I T}-T C_{t}
$$

Such rents only explain the spatial efficiency or inefficiency between two markets and do not account for trade flows. Following Barrett and Li (2002) we therefore divide each of the three cases above into two subcategories depending on whether (a) trade does or (b) does not flow. The result is a total of $j=6$ regimes, which occur with probability $\lambda_{j}$ (see Table 2 ).

Whenever trade occurs, markets are physically integrated. If there are no observable trade flows, markets are not integrated but segmented, irrespective of their efficiency. In regime 1, there is perfect integration, as markets are physically integrated and in an efficient spatial equilibrium (zero rents). Regimes 3 and 5 describe physically integrated markets but in a state of market disequilibrium with positive or negative rents (imperfect integration). Regimes 2 and 6 represent segmented equilibrium because there is no trade, but this is in line with spatial equilibrium conditions, as rents for trade would be zero (regime 2) or even negative (regime 6). Finally, in regime 4, markets are in segmented disequilibrium because the lack of trade means that they are not integrated even though positive rents remain unexploited.

Table 2: Description of the six possible regimes

$\begin{array}{lccc} & P_{t}^{C H}-P_{t}^{I T}=T C_{t} & P_{t}^{C H}-P_{t}^{I T}>T C_{t} & P_{t}^{C H}-P_{t}^{I T}<T C_{t} \\ & \left(R_{t}=0\right) & \left(R_{t}>0\right) & \left(R_{t}<0\right) \\ \text { Trade } & \lambda_{1} & \lambda_{3} & \lambda_{5} \\ & \text { (perfect integration) } & \text { (imperfect integration) } & \text { (imperfect integration) } \\ \text { No Trade } & \lambda_{2} & \lambda_{4} & \lambda_{6} \\ & \text { (segmented equilibrium) } & \text { (segmented disequilibrium) } & \text { (segmented equilibrium) }\end{array}$

$\mathrm{P}^{\mathrm{CH}}=$ Swiss price, $\mathrm{P}^{\mathrm{IT}}=$ Italian price, $\mathrm{R}=$ Rent, $\mathrm{TC}=$ Trade Cost, $\lambda_{\mathrm{k}}=$ Probability of regime $\mathrm{k}$ Source: own representation, based on Barrett and $\mathrm{Li}$ (2002)

For rent estimation, we allow for a sampling and measurement error $v_{t}$, with mean $\alpha$ and variance $\sigma_{v}^{2}$. The potentially non-zero mean $\alpha$ accounts for permanent, time-invariant factors such 
as the unobservable trade cost components in Fixcost and the difference between retail $(\mathrm{CH})$ and wholesale (IT) price level. The variance parameters account for all other transitory measurement differences or errors. For example, we convert all prices into one currency, even though not all exchange rate changes are passed on immediately (Liefert and Persaud 2009), leading to temporary errors in our estimates of the difference between Swiss and Italian tomato prices.

To estimate the probabilities of the regimes, we need to assume some distribution of the data generating process, even though this is naturally unknown and not observable. Following the PBM literature (Baulch 1997, Barrett and Li 2002) we assume that the rents $R_{t}$ are described by a half-normal distribution. ${ }^{17}$

$$
R_{t}=\begin{array}{cc}
v_{t}+u_{t} & \left(\text { for } R_{t}>0\right) \\
v_{t} & \left(\text { for } R_{t}=0\right) \\
v_{t}-u_{t} & \left(\text { for } R_{t}<0\right)
\end{array}
$$

For $R_{t} \neq 0$, we add a positive half-normal error term $u_{t}$ with variance $\sigma_{u}^{2}$. This error term is independent of the general sampling and measurement error $v_{t}$ and reflects the additional variation of positive and negative rents. The result is the following specification of the distribution functions for each regime:

$$
\begin{array}{ll}
f_{t}^{1}=f_{t}^{2}=\frac{1}{\sigma_{v}} \varphi\left[\frac{R_{t}-\alpha}{\sigma_{v}}\right] & \left(\text { regime 1+2, } \mathrm{R}_{\mathrm{t}}=0\right) \\
f_{t}^{3}=f_{t}^{4}=\left[\frac{2}{\left(\sigma_{u}^{2}+\sigma_{v}^{2}\right)^{1 / 2}}\right] \varphi\left[\frac{R_{t}-\alpha}{\left(\sigma_{u}^{2}+\sigma_{v}^{2}\right)^{1 / 2}}\right] *\left[1-\Phi\left[\frac{-\left(R_{t}-\alpha\right) \sigma_{u} / \sigma_{v}}{\left(\sigma_{u}^{2}+\sigma_{v}^{2}\right)^{1 / 2}}\right]\right] & \left(\text { regime 3+4, } \mathrm{R}_{\mathrm{t}}>0\right) \\
f_{t}^{5}=f_{t}^{6}=\left[\frac{2}{\left(\sigma_{u}^{2}+\sigma_{v}^{2}\right)^{1 / 2}}\right] \varphi\left[\frac{R_{t}-\alpha}{\left(\sigma_{u}^{2}+\sigma_{v}^{2}\right)^{1 / 2}}\right] *\left[1-\Phi\left[\frac{\left(R_{t}-\alpha\right) \sigma_{u} / \sigma_{v}}{\left(\sigma_{u}^{2}+\sigma_{v}^{2}\right)^{1 / 2}}\right]\right. & \left(\text { regime 5+6, } \mathrm{R}_{\mathrm{t}}<0\right)
\end{array}
$$

where $\varphi$ is the standard normal density function and $\Phi$ is the standard normal cumulative distribution function. Using these distribution functions, we can define the likelihood of observing the sample data $\left\{R_{t}\right.$, Trade $\left._{t}\right\}$ as

$$
L=\prod_{t=1}^{T}\left(A_{t} *\left[\lambda_{1} f_{t}^{1}+\lambda_{3} f_{t}^{3}+\lambda_{5} f_{t}^{5}\right]+\left(1-A_{t}\right) *\left[\lambda_{2} f_{t}^{2}+\lambda_{4} f_{t}^{4}+\lambda_{6} f_{t}^{6}\right]\right)
$$

17 Fackler and Goodwin (2001) point out that this is arbitrary, and the results of PBM estimation are known to be sensitive to this assumption. However, Figure A1 in the on-line appendix shows that the observed rents' distribution indeed follows an approximately half-normal pattern if correcting for the constant measurement error. Further, we apply a distribution-independent block bootstrapping procedure to our model results (section 4). 
The variable $A_{t}$ takes the value one when trade takes place in week $t$, and zero otherwise. $\lambda_{k}$ states the probabilities of the six regimes. Maximizing the log-likelihood function in equation (13) generates estimates for the error parameters $\alpha, \sigma_{u}$ and $\sigma_{v}$. To do so we use the 'L-BFGS$B$ ' method proposed by Byrd et al. (1995) subject to the constraints $0 \leq \lambda_{k} \leq 1$ and $\sum_{k} \lambda_{k}=$ 1. As a result of the distributional assumptions and the included error terms, the regimes are separated by parity bounds that allow for some variation, so that even in the zero rents regimes, rents do not need to be precisely zero (see Baulch 1997).

The key variable in this model is the series of weekly rents $\left(R_{t}\right)$. Due to the non-linearity of the Swiss TRQ system, we distinguish between average and marginal rents. For average rents, we consider volume-weighted weekly average tariff costs (Tariff ${ }^{\text {avg }}$, equation 1). This reflects the average rents realised by the actors who imported tomatoes in that week, either at in-quota or out-of-quota tariffs. In contrast, the marginal rents represent the rents realised by the importer who paid the highest tariff rate in a given week (Tariff marg , equation 2). We analyse both types of rents because average rents tell us about the observed market outcome and marginal rents about the outcome for potential market entrants.

\section{Results}

\subsection{Descriptive analysis}

We see clear seasonal patterns in the Swiss-Italian price difference, tariff costs and trade flows. Table 3 and Figure 2 visualize these differences for all analysed variables. In the non-administered period when quotas are not effective and borders are open for unlimited tomato imports, the average price difference is relatively low at $1.43 \mathrm{CHF} / \mathrm{kg}$ and the average applied tariff is only $0.03 \mathrm{CHF} / \mathrm{kg}$. During the administered summer period (ca. June-September) when only limited amounts of imports enter at the low in-quota tariff, both values increase; the average applied tariff is $1.03 \mathrm{CHF} / \mathrm{kg}$, and the price gap between Switzerland and Italy rises to 2.39 $\mathrm{CHF} / \mathrm{kg}$. 
Table 3: Summary statistics of observed variables (mean and standard deviation)

\begin{tabular}{lcccc} 
& $\begin{array}{c}P^{C H}-P^{I T} \\
(\mathrm{CHF} / \mathrm{kg})\end{array}$ & $\begin{array}{c}\text { Tariff } \\
(\mathrm{CHF} / \mathrm{kg})\end{array}$ & $\begin{array}{c}\text { Tariff } \\
(\mathrm{CHF} / \mathrm{kg})\end{array}$ & $\begin{array}{c}\text { Trade volume } \\
\text { (tons/week) }\end{array}$ \\
\hline All observations & 1.77 & 0.38 & 0.80 & 42.30 \\
& $(0.67)$ & $(0.59)$ & $(1.06)$ & $(35.51)$ \\
Administered period & 2.39 & 1.03 & 2.16 & 7.96 \\
& $(0.55)$ & $(0.59)$ & $(0.56)$ & $(11.41)$ \\
Non-administered period & 1.43 & 0.03 & 0.05 & 63.10 \\
& $(0.45)$ & $(0.02)$ & $(0.00)$ & $(28.22)$ \\
\hline
\end{tabular}

Source: own calculation. The non-administered period includes prolongations.

Standard deviations are reported in parentheses.

Figure 2 illustrates the pattern of trade flows. We consider any week in which Switzerland imports at least 5 tons of tomatoes from Italy to be a 'trade week', and these weeks are shaded in Figure 2. We consider weekly imports of fewer than 5 tons to be negligible and the corresponding weeks to be 'no-trade weeks' ${ }^{18}$ From roughly October to June of most years there are constant trade flows from Italy to Switzerland, indicating physical market integration. From July to September, however, there are (almost) no Italian tomato imports. Hence, during the domestic tomato season when TRQs are administered, the Italian and Swiss markets are segmented.

To determine whether Swiss and Italian tomato markets are efficient, we estimate the rents over time. We define rents as the difference between the Swiss and the Italian prices minus the trade costs. Trade costs are made up of variable tariff costs plus other fixed transport and marketing costs (compare section 3). We observe the tariff costs, but data on the fixed, non-tariff trade costs are missing. Furthermore, since we compare Swiss retail prices with Italian wholesale prices, the price difference also includes an unobserved positive wholesale-retail marketing margin. Due to these unobserved cost components we cannot directly estimate rent levels. However, if we assume that the non-tariff trade and marketing costs are constant over time (and captured in the constant $\alpha$, which is jointly estimated with all other parameters in the PBM) then we can estimate changes in rents from week to week during our sample period.

\footnotetext{
18 This threshold is chosen rather arbitrarily, assuming that large commercial imports start at approximately one ton per weekday. In shifting this threshold between 3 and 8 tons per week, the results remain qualitatively the same.
} 


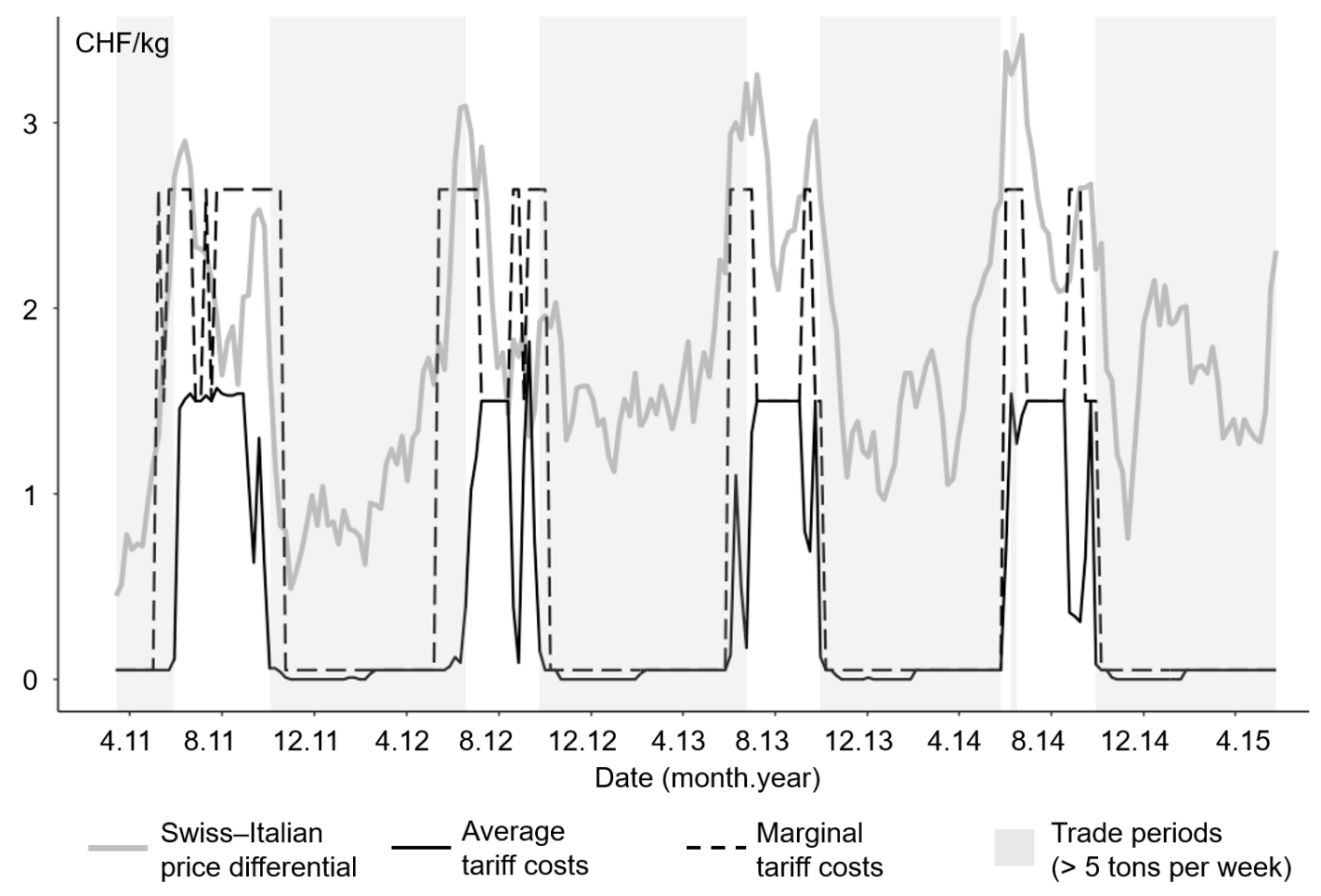

Figure 2: Relationships between price differentials, trade flows and tariff costs

\subsection{Parity bounds model estimation results}

Table 4 summarizes the PBM estimation results. As expected, the constant measurement error is positive ( $\alpha=1.826$ ), as an estimate of the non-tariff costs and the retail/wholesale markup, assumed constant over the period. Looking at the regime probabilities for average rents, there are three striking results. First, regimes with positive rents account for more than $60 \%$ of the total sample period $\left(\lambda_{3}+\lambda_{4}\right)$. Second, efficient market equilibrium with zero rents is only reached in $22.9 \%$ of all weeks $\left(\lambda_{1}\right)$. Finally, when there are negative rents, no or only negligible (fewer than 5 tons) trade takes place, implying that importers react rationally to arbitrage opportunities $\left(\lambda_{6}=15.7 \%\right.$, while $\left.\lambda_{5}=0 \%\right)$. Overall, these results, which are based on weighted average tariffs suggest the existence of inefficiencies and large opportunities for positive importer rents over much of the sample period. 
Table 4: Maximum likelihood estimates of regime frequencies for Italian tomato imports

\begin{tabular}{ccccccccccc} 
& \multicolumn{2}{c}{ No rents } & \multicolumn{2}{c}{ Positive rents } & \multicolumn{2}{c}{ Negative rents } & \multicolumn{2}{c}{ Error term estimates } \\
\hline & $\begin{array}{c}\boldsymbol{\lambda}_{\mathbf{1}} \\
\text { (trade) }\end{array}$ & $\boldsymbol{\lambda}_{\mathbf{2}}$ & $\boldsymbol{\lambda}_{\mathbf{3}}$ & $\boldsymbol{\lambda}_{\mathbf{4}}$ & $\boldsymbol{\lambda}_{\mathbf{5}}$ & $\boldsymbol{\lambda}_{\mathbf{6}}$ & $\boldsymbol{\alpha}$ & $\boldsymbol{\sigma}_{\mathbf{u}}$ & $\boldsymbol{\sigma}_{\mathbf{v}}$ \\
\hline \multirow{3}{*}{ Average rent } & (trade) & (no trade) & (trade) & (no trade) & $\boldsymbol{\alpha}$ & & & \\
& 0.229 & 0.000 & 0.512 & 0.102 & 0.000 & 0.157 & 1.826 & 0.561 & 0.381 \\
& $(0.086)$ & $(0.032)$ & $(0.184)$ & $(0.050)$ & $(0.024)$ & $(0.044)$ & $(0.222)$ & $(0.127)$ & $(0.105)$ \\
Marginal rent & 0.642 & 0.011 & 0.000 & 0.000 & 0.099 & 0.248 & $1.826^{*}$ & 1.187 & 0.522 \\
& $(0.191)$ & $(0.002)$ & $(0.019)$ & $(0.008)$ & $(0.036)$ & $(0.032)$ & $(\mathrm{n} / \mathrm{a})$ & $(0.235)$ & $(0.100)$ \\
\hline
\end{tabular}

$* \alpha$ is fixed to the level of the estimation with average rents, as marginal rents do not reflect the actual market outcome. 'No trade' refers to trade volumes of fewer than 5 tons per week. Robust standard errors reported in parentheses.

Standard errors are calculated with block bootstrapping ( 4 blocks of 55 weeks each to cover all seasons, 10,000 bootstrap samples). These are robust standard errors for the actual sample distribution, independent of distributional assumptions (Künsch 1989). For average rents, 53 out of the 10,000 simulated samples did not converge in the maximum likelihood estimation and were replaced by the original sample.

Analysing rents based on marginal tariffs gives a different picture. The perfect market equilibrium with zero marginal rents and trade $\left(\lambda_{1}\right)$ accounts for $64.2 \%$ of all weeks, and positive marginal rents are not observed in any weeks $\left(\lambda_{3}=\lambda_{4}=0\right)$. In weeks with no trade, marginal rents are usually negative $\left(\lambda_{6}=24.8 \%\right)$ and at most zero $\left(\lambda_{2}=1.1 \%\right)$. Hence, for non-quota holders, the applied tariffs are prohibitive. There is no opportunity at all for positive rents, and with almost $35 \%$, rents are even negative $\left(\lambda_{5}+\lambda_{6}\right)$, providing no incentive to enter the market.

The above estimates resulting from the maximum likelihood estimation are all time-invariant over the whole sample period. To better understand the seasonal patterns of the regime prevalence, we construct a time-varying variable $\tilde{\lambda}_{t}^{k}$. This binary indicator variable defines which regime $k$ has the highest probability of occurring at each point in time $t$. In times of no or negligible trade $\left(A_{t}=0\right)$, we compare the conditional probabilities of regimes 1, 3 and 5 . In times of trade $\left(A_{t}=1\right)$, we compare the conditional probabilities of regimes 2,4 and $6 .{ }^{19} \mathrm{We}$ aggregate the variable $\tilde{\lambda}_{t}^{k}$ over the observed years and calculate seasonal averages for each calendar week. Figure 3 displays the regime probabilities throughout the year, based on average rents.

\footnotetext{
19 The exact construction of the variable is derived in Barrett and Li (2002), p. 289.
} 


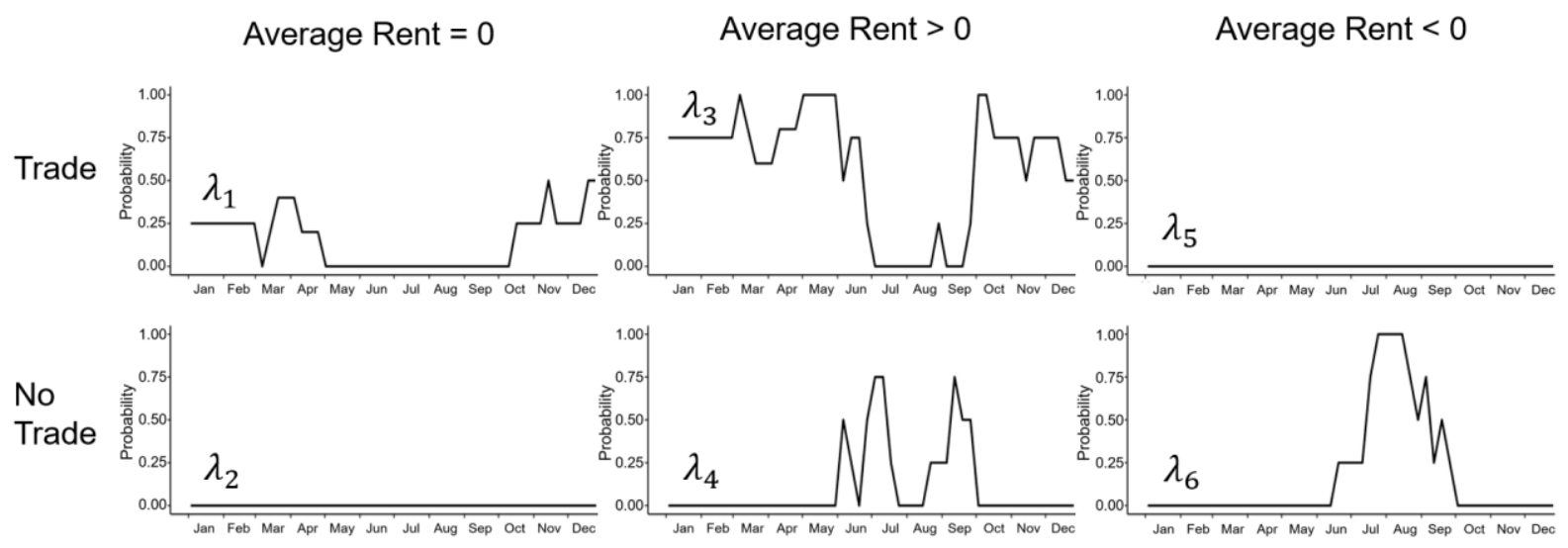

Figure 3: Seasonal regime probabilities for Italian-Swiss tomato trade (average rents)

Source: Own calculations of time-varying conditional regime probabilities $\tilde{\lambda}_{t}^{k}$, aggregated per ISO calendar week.

Periods of market integration with trade prevail in the non-administered period and its prolongations (October-early June). These periods are most often characterised by positive rents $\left(\lambda_{3}\right)$ but sometimes also by zero rents $\left(\lambda_{1}\right)$. The probability of negative rents is consistently zero.

In periods of no trade (i.e. in the administered period in summer), regime 2 , in which markets are efficient and rents equal zero is never observed $\left(\lambda_{2}=0\right)$. Instead, when quotas are released and in-quota imports prevail, average rents are most likely to be positive $\left(\lambda_{4}\right)$. Later on in the administered period, when there is full domestic supply and no quotas are opened, particularly mid-July until early September, average rents become negative $\left(\lambda_{6}\right)$ because the high out-ofquota tariffs apply to all imports.

Marginal Rent $=0$

Marginal Rent $>0$

Marginal Rent $<0$
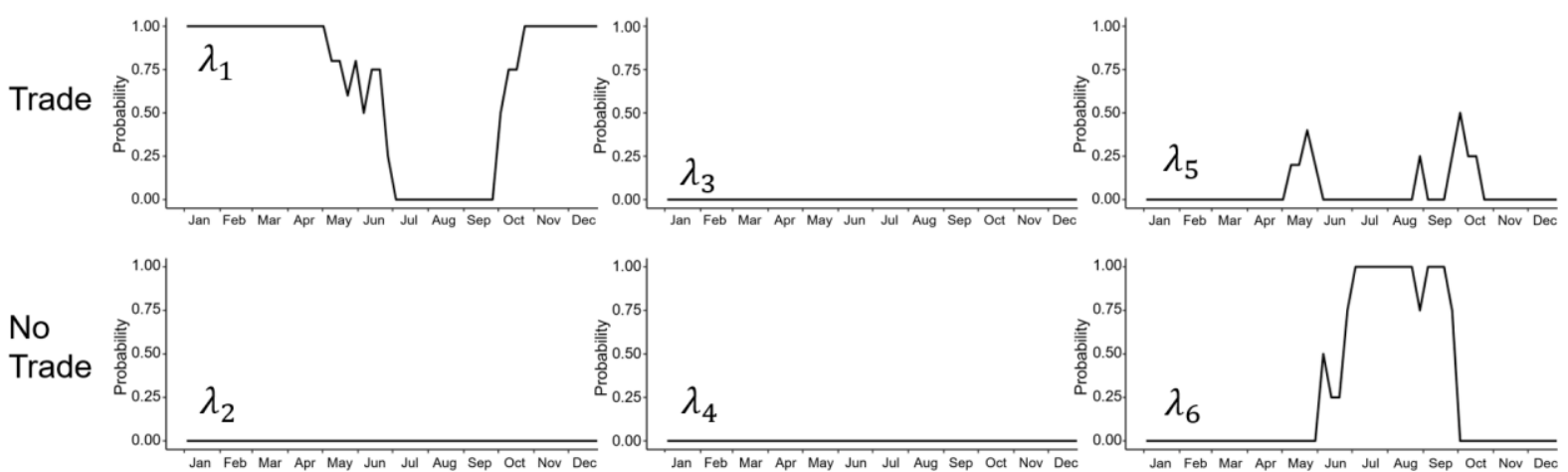

Figure 4: Seasonal regime probabilities for Italian-Swiss tomato trade (marginal rents) Source: Own calculations of time-varying conditional regime probabilities $\tilde{\lambda}_{t}^{k}$, aggregated per ISO calendar week. 
Looking at marginal rents, however, the situation is different (Figure 4). During the winter months, there is a $100 \%$ probability that marginal rents are zero $\left(\lambda_{1}=1\right)$, indicating that markets are in equilibrium and additional importers are free to enter the market. During the potential prolongation periods (May, October), rents are more often zero $\left(\lambda_{1}>0.5\right)$ than negative $\left(\lambda_{5}<\right.$ 0.5). Finally, in times of no trade in the summer months, marginal rents are always negative $\left(\lambda_{6}\right)$. This suggests that quotas are binding and any additional imports would yield negative rents, providing no incentive for traders who do not hold quota shares to be active on the market.

\subsection{Limitations}

All the above estimates should be interpreted with care and seen as approximations rather than precise numerical results. Tests with simulated data and block bootstrapping procedures show that for relatively small sample sizes (in our case 220 observations), our model does converge to the true parameters without systematic bias but with some imprecision. The bootstrapped robust standard errors (Table 4) demonstrate that the estimates are significant, but display large variances. In particular, an imprecise estimate of the constant measurement error $(\alpha=1.826$, with robust standard error $=0.222$ ) could bias our results. $\alpha$ captures the constant measurement gap between wholesale and retail prices, as well as constant, non-tariff trade costs, and it is estimated based on distributional assumptions (see section 3). If $\alpha$ is overestimated, all rents are underestimated. The above described rent distribution would shift upward, with less negative and more positive rents. Analogously, underestimating $\alpha$ would mean that true rents are constantly lower than our results. In either case, this would affect only the overall level of rents and not their seasonal distribution. Hence, our conclusions regarding the administered and nonadministered periods would still hold. For marginal rents, we do not re-calculate $\alpha$ but take the value estimated from the average rents because our distributional assumptions are valid for actually observed rents and not for their marginal behaviour.

A further limitation of our study concerns the question of who actually captures the rents. The rent is generated at the stage of the importers. Previous studies have looked at TRQ systems with respect to industry competition and market power (e.g. Scoppola 2010, Pouliot and Larue 2012). In Switzerland, the large retailers import directly and hold import quotas themselves. Additionally, they are supplied by different importing companies. Because of this vertical integration and multiple supply relationships, we suspect but cannot prove that at least part of the importer rents are captured by downstream retailers. 


\section{Discussion and Conclusion}

We analysed tomato trade from Italy to Switzerland under a seasonal TRQ system. Incorporating detailed price, trade flow and cost data, we examine market integration (i.e. physical trade) and market efficiency (i.e. rent generation). We conclude that seasonal TRQs for tomato imports succeed in protecting high-cost domestic production in Switzerland, but at the cost of large inefficiencies.

Our analysis shows that both market integration and market efficiency differ between the administered summer period and the non-administered winter period. In the non-administered period, only the low in-quota tariff applies and causes little market distortion, so that markets are mostly in equilibrium with zero rents for importers. During this time, there are unrestricted large import flows and importers are free to enter the market. This is politically desired, as there is no domestic tomato production to be protected, and consumers benefit from a large variety of low-cost imports.

During the administered period, however, the TRQ system functions like a flexible quota. Cheap in-quota imports are only allowed when there is a domestic supply shortage, and these quotas are completely filled. The quota holders benefit from large rents, while marginal rents are negative, so above-quota imports are unattractive and the quota is binding. As quota shares are allocated based on historical purchase volumes, only the large established players profit, while new market entrants are kept out of the market. This mechanism is reinforced by the fact that private market players, via their participation in the umbrella organization Swisslegumes, themselves determine when and how many quotas will be opened. Therefore, the system contributes to maintaining the status quo of high market concentration among importers and retailers.

Eventually, Swiss consumers pay the price for this seasonal protection through high retail prices during the administered period. Indeed, for Swiss consumers domestic tomatoes are more expensive in season than imported tomatoes out of season. Swiss tomato producers clearly benefit, as the price gap to foreign markets (here Italy) increases substantially during the administered domestic season, and the Swiss price becomes completely detached from foreign market developments. The seasonal administration maintains high and stable domestic prices as long as there are Swiss tomatoes on the market. Furthermore, maintaining high prices and limiting imports ensures that there is domestic production in the first place and thus contributes to the goal of higher self-sufficiency. However, TRQs specifically and border protection in general are certainly not the most targeted and efficient means of supporting farm incomes, as stressed by 
Gray et al. (2017). And it can be questioned whether increasing self-sufficiency for a non-staple food product such as tomatoes justifies the many market distortions and inefficiencies associated with the TRQ system, especially because Switzerland remains fully import dependent out of season.

Comparing our findings for seasonal TRQs with previous studies on non-seasonal TRQs, we conclude the following. The criticism of non-seasonal TRQs also applies to seasonal TRQs during the administered periods. The goal of tariffication is not reached, as the seasonal TRQ mimics a pure quota and thus represents a non-tariff barrier. In addition, quota-holders capture large rents, and the historical allocation mechanism is discriminatory against new market entrants. In contrast with non-seasonal TRQs, however, the seasonal administration limits these distortions and inefficiencies to the few months each year in which there is domestic production. Moreover, the consensual weekly quota openings coordinated by Swisslegumes in the administered period allow the system to flexibly react to domestic supply conditions by adjusting imports quantities. This makes the instrument attractive for fresh produce with limited storability. The distinction between administered and non-administered periods also makes price stability effects more predictable than under normal TRQs. During the administered period, domestic prices are high, stable and insulated from foreign developments. For the rest of the year, international price signals can be passed on through almost unrestricted trade. 


\section{References}

Abbott, P. C. (2002). Tariff-rate quotas: failed market access instruments?. European Review of Agricultural Economics, 29(1), 109-130.

Abbott, P. C., and Paarlberg, P.L. (1998). Tariff rate quotas: structural and stability impacts in growing markets. Agricultural Economics, 19(3), 257-267.

Barrett, C. B. (2001). Measuring integration and efficiency in international agricultural markets. Review of Agricultural Economics, 23(1), 19-32.

Barrett, C. B., and Li, J. R. (2002). Distinguishing between equilibrium and integration in spatial price analysis. American Journal of Agricultural Economics, 84(2), 292-307.

Baulch, B. (1997). Transfer costs, spatial arbitrage, and testing for food market integration. American Journal of Agricultural Economics, 79(2), 477-487.

Beckman, J., Dyck, J. H., and Heerman, K. E. (2017). The Global Landscape of Agricultural Trade, 1995-2014. US Department of Agriculture, Economic Research Service.

Boughner, D. S., de Gorter, H., and Sheldon, I. M. (2000). The economics of two-tier tariff-rate import quotas in agriculture. Agricultural and Resource Economics Review, 29(1), 5869.

Byrd, R. H., Lu, P., Nocedal, J., and Zhu, C. (1995). A limited memory algorithm for bound constrained optimization. SIAM Journal on Scientific Computing, 16(5), 1190-1208.

De Gorter, H., and Kliauga, E. (2006). Reducing tariffs versus expanding tariff rate quotas. Agricultural Trade Reform and the Doha Development Agenda, 117-160.

Fackler, P. L., and Goodwin, B. K. (2001). Spatial price analysis. Handbook of Agricultural Economics, 1, 971-1024.

Ferjani, A., Mann, S., and Zimmermann, A. (2018). An evaluation of Swiss agriculture's contribution to food security with decision support system for food security strategy, British Food Journal, 120(9), 2116-2128.

Gibson, P. R., Wainio, J., Whitley, D. B., and Bohman, M. (2001). Profiles of tariffs in global agricultural markets. US Department of Agriculture, Economic Research Service (Report No. 34055). 
Gray, E., Adenäuer, L., Flaig, D., and van Tongeren, F. (2017). Evaluation of the relevance of border protection for agriculture in Switzerland, OECD Food, Agriculture and Fisheries Papers, No. 109 (OECD Publishing, Paris).

Hranaiova, J., and Gorter, H. D. (2005). Rent Seeking with Politically Contestable Rights to Tariff-rate Import Quotas. Review of International Economics, 13(4), 805-821.

Künsch, H. R. (1989). The jackknife and the bootstrap for general stationary observations. The Annals of Statistics, 17(3), 1217-1241.

Liefert, W., and Persaud, S. (2009). The transmission of exchange rate changes to agricultural prices. Economic Research Report, 76, USDA.

Loi, A., Esposti, R., Gentile, M., Aragrande, M., Bruni, M., Berisio, S., and Saguatti, A. (2016). Policy evaluation of tariff rate quotas. Report mandated by the Swiss federal Office of Agriculture. Arete, Bologna.

Park, A., Jin, H., Rozelle, S., and Huang, J. (2002). Market emergence and transition: arbitrage, transaction costs, and autarky in China's grain markets. American Journal of Agricultural Economics, 84(1), 67-82.

Pouliot, S., and Larue, B. (2012). Import sensitive products and perverse tariff-rate quota liberalization. Canadian Journal of Economics/Revue canadienne d'économique, 45(3), 903924.

Scoppola, M. (2010). The liberalisation of tariff rate quotas under oligopolistic competition. Journal of agricultural economics, 61(3), 584-604.

Skully, D. W. (2001). Economics of tariff-rate quota administration. US Department of Agriculture, Economic Research Service.

Spiller, P. T., and Huang, C. J. (1986). On the extent of the market: wholesale gasoline in the northeastern United States. The Journal of Industrial Economics, 35(2), 131-145.

Swiss Federal Council (2008). Ordinance on Rates of Duty for Goods in trade with member states of EFTA and the EU (Free Trade Ordinance 1, SR 632.421.0, 18 June 2008). Available at https://www.admin.ch/opc/de/official-compilation/2008/3519.pdf, last accessed 13 November 2018. 
Swiss Federal Council (1994). Message on the approval of the GATT/WTO Agreements (Uruguay Round) (SR 94.079, 19 September 1994). Available at https://www.amts druckschriften.bar.admin.ch/viewOrigDoc/10107964.pdf?id=10107964\&action=open, last accessed 13 November 2018.

WTO (World Trade Organization) (2018). Tariff Download Facility. Available at http://tariffdata.wto.org/, last accessed 13 November 2018. 


\section{Appendix}

Table A1: Swiss tariff rates for tomato imports from the EU

\begin{tabular}{lllll}
$\begin{array}{l}\text { Product } \\
\text { description }\end{array}$ & Tariff Nr. & Description & $\begin{array}{l}\text { Timeframe } \\
(\text { month/day })\end{array}$ & $\begin{array}{l}\text { Tariff }(\mathrm{CHF} \\
\text { per kg gross })\end{array}$ \\
\hline & 0702.0090 & $\begin{array}{l}\text { non-administered pe- } \\
\text { riod }\end{array}$ & $10 / 21-04 / 30$ & $0.00 * / 0.05$ \\
\cline { 2 - 5 } $\begin{array}{l}\text { round tomatoes, } \\
\text { diameter }<80 \mathrm{~mm} \\
\text { (non- cherry and } \\
\text { non-Peretti) }\end{array}$ & 0702.0091 & in-quota tariff & $05 / 01-10 / 20$ & 0.05 \\
\cline { 2 - 5 } & 0702.0099 & out-of-quota tariff & $05 / 01-10 / 20$ & 2.64 \\
\cline { 2 - 5 } & 0702.0099 & $\begin{array}{l}\text { reduced out-of-quota } \\
\text { tariff (during full sup- } \\
\text { ply period) }\end{array}$ & $05 / 01-10 / 20$ & 1.50 \\
& & & \\
\hline
\end{tabular}

Source: Swiss Federal Customs Administration

*Duty free imports are granted for EU/EFTA imports up to 10'000 t net p.a. (for all tomatoes, TRQ nr. 106)

\section{Figure A1: Density function of the observed average rents}

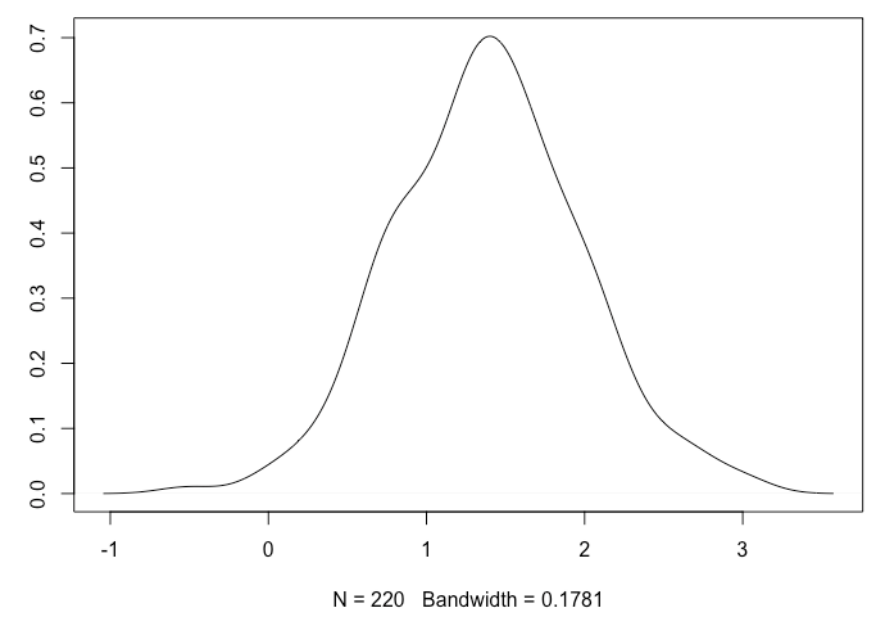

Source: own representation of observed weekly average rents, defined as $R_{t}^{o b s}=P_{t}^{C H}-P_{t}^{I T}-\operatorname{Tariff}_{t}^{a v g}$ 


\section{Concluding Remarks}

The overall objective of this dissertation is to contribute to a better understanding of agricultural and food price transmission in Switzerland. To do so, the articles in the three previous chapters provided empirical analyses of Swiss prices. The studying of horizontal and vertical price transmission in the Swiss milk market was complemented by an analysis of market integration and market efficiency under the Swiss seasonal tariff rate quota (TRQ) system. This final chapter summarizes the results, indicates how far the original research questions are answered and brings up issues that might merit further investigation.

\section{Summary of the results}

The first article, "Protecting the Swiss milk market from foreign price shocks: Public border protection vs. quality differentiation," dealt with spatial price transmission between German and Swiss milk markets. We investigated both cheese and dairy products at wholesale and producer levels. We showed that the price pass-through from Germany to Switzerland is higher for raw milk producer prices than for processed products' wholesale prices, even though raw milk is not traded between the two countries. At the wholesale level, cheese trade is fully liberalized whereas other dairy products are still subject to tariffs and TRQs. At both producer and wholesale level, German prices influence Swiss prices more in the tariff-protected industrial dairy processing channel than for liberalized cheese products. This may seem surprising, but it is not only the level of trade protection that differs between dairy and cheese products. For Swiss cheese, there is a high degree of quality differentiation, for both the raw milk (e.g., silage-free feeding, regional restrictions) and the actual product processing (e.g., artisanal production, specialty brands). Other dairy products such as milk powder or butter are considered more homogeneous and are made from generic pasteurized milk. Our results indicate that this qualitative differentiation limits spatial price transmission between Switzerland and Germany, because international substitutability is reduced. For the analyzed milk products, this aspect seems to be more relevant than the type or degree of border protection or the physical trade volume. We interpret this finding as evidence that qualitative product differentiation by producers and processors contributes more than public trade policies to segmenting the Swiss market from the surrounding EU market.

The second article, "Vertical price transmission in Swiss dairy and cheese value chains," assessed how milk prices are passed on within Switzerland along the processing lines. We found only weak price links along Swiss dairy and cheese chains, i.e., between producer, wholesale, 
export and retail prices of a respective product. Neither for dairy nor for cheese products, convincing evidence for long-run vertical price transmission could be found. Especially the initial hypothesis that prices are passed on more fully and quickly in artisanal cheese value chains with high price transparency than in industrialized, highly concentrated dairy chains could not be confirmed. We found (threshold) cointegration only for six out of 24 price pairs, not allowing us to draw a clear conclusion because cointegration was partly found in the dairy chain (butter), cheese chain (Gruyère) and organic chain (organic milk and butter). These results are contrary to most previous findings for milk markets in other countries, because most of them showed evidence for long-run price transmission with asymmetries regarding the pass-through of price increases or decreases. Our analysis did not reveal any systematic asymmetries and showed almost no long-run vertical price transmission in Swiss milk markets. This finding could be due to statistical properties and limited data availability of our price series or to Switzerland-specific factors such as the fragmented farm structure, high governmental support and the overall high price and cost levels in Switzerland.

The third article, "Market integration and market efficiency under seasonal tariff rate quotas," dealt with Switzerland's seasonal TRQ system. It examined how this system affects the relationship between Italian and Swiss tomato prices and trade patterns. Incorporating detailed price, trade flow and tariff cost data, we analyzed market integration (i.e., physical trade) and market efficiency (i.e., rent generation). The study showed large differences between the administered summer period and the non-administered winter period, regarding both market integration and market efficiency. Outside the Swiss tomato season, TRQs are not administered and only the low in-quota tariff applies, causing little market distortion. During this time, markets are mostly in equilibrium with zero rents for importers. There are constantly large import volumes, and importers are free to enter the market. This situation is politically desired because there is no domestic tomato production to be protected and consumers benefit from a large variety of low-cost imports. In the summer season, however, when TRQs are in place, markets are inefficient. The price gap to Italy increases substantially, and the Swiss price becomes completely detached from foreign market developments. This independence allows Swiss producers to sell their produce at high, stable prices, without having to fear competition from cheap imports. Whereas import quota holders receive positive rents, the marginal rents for importers without access to quota shares are negative. This inhibits trade flows above the in-quota import quantity allowed by TRQs. Hence, despite leading to inefficiencies and creating rents for importers, seasonal TRQs are an effective and flexible instrument to shield domestic production against competing imports. 
Overall, this thesis has shown that Swiss agricultural and food markets remain characterized by high prices and segmented from the surrounding EU markets. This is at least partly due to the protective trade policies. Especially the seasonal TRQ system shields Swiss producers from international price signals and from any foreign competition. There is no need for producers to operate competitively or to react to price signals. The system ensures that they can sell their products at high prices, and therefore it increases their farm income. Although beneficial for domestic producers, this system leads to inefficiencies, in particular to high rents for importers and even higher prices for consumers. It is questionable whether such a complex, costly, and trade-distorting system is the right tool to ensure domestic production and to support domestic farm income.

In fact, the case of the liberalized cheese markets shows that there are other ways to maintain high and stable prices, such as the promotion of high-quality differentiated products. Compared with players in the tariff-protected industrial dairy processing line, producers and processors in the cheese value chains realize higher prices and are less dependent on international price developments. With the help of some general, non-trade-distorting subsidies, they manage to be competitive internationally despite high production costs. They sustain their position in the Swiss market against cheaper, duty-free imports and are successful in export markets. From a policy perspective, these findings suggest a benefit in preferring decoupled subsidies and direct payments over tariff-based protectionism. Governmental support could help to position Swiss products in high-quality segments and to communicate this quality accordingly.

\section{Outlook on future research}

Based on the outcome of the three articles in this thesis, but even more based on the research process itself, I would like to stress two aspects that I consider to deserve further investigation: first, the role of market structure and market power, and second, an extension of the used price data.

This thesis does not explicitly analyze the role of Swiss market structure in price transmission or price setting in general. However, market structure and potentially resulting market power are relevant elements to understand both vertical and horizontal price transmission (e.g., McCorriston et al. 1998, Bakucs et al. 2014). This is also true for Switzerland, where already in 1992 the Organisation for Economic Co-operation and Development (OECD) suspected "widespread horizontal and vertical collusive arrangements" to contribute to higher and more rigid prices than in neighboring countries (OECD 1992, p. 68). The OECD's most recent study 
confirms the viewpoint that the high price level is partly "driven by weak competition" (OECD 2017, p. 87).

Besides concentration, i.e., the number of players in the market, the degree of cooperation and the network among these players are crucial. In the relatively small Swiss market, sector associations and umbrella organizations play an important role (SECO 2008, Reviron et al. 2017). Therefore, a simple measuring of concentration ratios or market shares will not be sufficient. Future research could focus on the role of these coordinating organizations, analyzing their role in vertical price transmission and whether a higher degree of cooperation leads to higher and more stable prices. Moreover, there are many interdependencies between governmental policy makers and these private market organizations. A clear separation between public policy and private market power is not always easy: The milk quota system, officially abolished in 2009, has for example been followed by a private law quota system, organized by the sector association. Also, in the seasonal TRQ system, private market players decide upon timing and volume of quota openings, as described in chapter IV. Making a clear public-private distinction or modeling the interdependencies will be a challenge. Tackling this field requires combining the econometric approaches used in classical price transmission with market structure analysis and with methods from the field of New Empirical Industrial Organizations (e.g., Weldegebriel 2004, Hong and Li 2017).

The second point I would like to highlight is that all of the three analyses suffer to some degree from data limitations. Whereas in this thesis monthly (chapters II and III) or at most weekly data (chapter IV) are used, higher frequency data (e.g., daily data) would help to get more observations for the same time period, to lose less information through timely aggregation and consequently to get better estimation results. Also, price data with less aggregation across product groups could lead to additional insights. Especially in the third article, dealing with fresh vegetable prices, we had to work with aggregate product prices for a certain type of tomatoes. Yet, these tomatoes and their prices are still highly heterogeneous, because they vary in quality, maturity, package size, greenhouse vs. outdoor production, etc. All price data are from secondary sources, making it difficult to determine how large the variance in prices really is and how this aggregation took place.

Having to deal with such non-ideal secondary source price data has led me to pursue a new research focus. Based on this experience, I started to integrate the process of price data collection into my own research. Collecting price data through web scraping is one approach that could help to overcome some of the data limitations of currently used price data sources 
(Cavallo and Rigobon 2016, Hillen 2018). The term web scraping describes the automated process of accessing websites and downloading specific information, such as prices (Edelman 2012). Especially at the retail stage, scraping price data from grocery shopping websites gives access to higher frequency and more detailed price data on a single product basis. Like in many other countries, online grocery shopping is playing an increasing role in the Swiss retail sector. Both start-ups and the large established retailers have launched online shopping websites with home delivery service, recording growing shares in the grocery retail landscape (Lang 2019). Retrieving price quotes from these websites leads to price data for more products, at a higher frequency (e.g., daily) with more information on product attributes (e.g., organic vs. conventional, Swiss vs. imported products). Using such scraped data could help not only to validate and to challenge the analyses made in this thesis but also to extend them by investigating the role of the growing online food retail sector with respect to price transmission and market integration. 


\section{References}

Bakucs, Z., Fałkowski, J., and Fertő, I. (2014). Does market structure influence price transmission in the agro-food sector? A meta-analysis perspective. Journal of Agricultural Economics, 65(1), 1-25.

Cavallo, A., and Rigobon, R. (2016). The Billion Prices Project: using online prices for measurement and research. Journal of Economic Perspectives, 30(2), 151-178.

Edelman, B. (2012). Using internet data for economic research. Journal of Economic Perspectives, 26(2), 189-206.

Hillen, J. (2018). Web scraping for food price research. 58th annual conference of the German Association of Agricultural Economists (GEWISOLA), 12-14 September 2018 in Kiel, Germany.

Hong, G. H., and Li, N. (2017). Market structure and cost pass-through in retail. Review of Economics and Statistics, 99(1), 151-166.

Lang, T. (2019). Lebensmittel Online: LeShop und coop@home weiterhin unangefochten. Carpathia Digital Commerce Blog, 19 January 2019. Available at https://blog.carpathia.ch/2019/01/19/lebensmittel-online-leshop-coophome-farmy-2018/, last accessed 7 August 2019.

McCorriston, S., Morgan, C. W., and Rayner, A. J. (1998). Processing technology, market power and price transmission. Journal of Agricultural Economics, 49(2), 185-201.

OECD (Organisation for Economic Co-operation and Development) (1992). Economic Surveys: Switzerland 1991/1992. OECD Publishing, Paris.

OECD (Organisation for Economic Co-operation and Development) (2017). Economic Surveys: Switzerland 2017. OECD Publishing, Paris.

Reviron, S., Python, P., Gresset, F., Estève, M., and Bänninger, A. (2017). Wertverteilung in der Wertschöpfungskette. Schlussbericht. Nr. 3177. Agridea, Lausanne. Available at https://agridea.abacuscity.ch/de/ 2044, last accessed 7 August 2019.

SECO (Swiss State Secretariat for Economic Affairs) (2008). Preisinsel Schweiz. Berichte in Erfüllung des Postulates David (05.3816). SECO, Bern. 
Weldegebriel, H. T. (2004). Imperfect price transmission: Is market power really to blame? Journal of Agricultural Economics, 55(1), 101-114. 


\section{Curriculum Vitae}

\section{Personal details}

Name:

Judith Hillen

Address:

Wülflingerstrasse 151a, CH-8408 Winterthur

Phone:

+41765296141

E-Mail:

judithhillen@web.de

Date/place of birth:

7. November 1988 in Neustadt/Weinstrasse (DE)

Nationality:

German

\section{Education}

since $04 / 2017$

External PhD Student

Department of Agricultural Economics and Rural Development

(Prof. Dr. Stephan von Cramon-Taubadel)

Georg-August-Universität Göttingen, Germany

$10 / 2014-09 / 2016$

M.Sc. in Agricultural and Food Economics

Rheinische Friedrich-Wilhelms-Universität Bonn, Germany

$10 / 2008-02 / 2012$

B.Sc. in International Economics

Eberhard-Karls-Universität Tübingen, Germany

$08 / 2010-12 / 2010$

Economics studies abroad (DAAD scholarship)

Universidade Federal Fluminense, Niterói, RJ, Brazil

$03 / 2008$

High School Graduation (Abitur)

Hannah-Arendt-Gymnasium, Hassloch (Pfalz), Germany

\section{Professional Experience}

Since $08 / 2018$

Agricultural Economist/Market Analyst

Agroscope Tänikon, Switzerland

$10 / 2016-07 / 2018$

Doctoral Researcher

Agroscope Tänikon, Switzerland 
$03 / 2015-03 / 2016$

$04 / 2012-06 / 2014$

$10 / 2011-02 / 2012$

$01 / 2011-04 / 2011$
Student Research Assistant

Chair for Technology and Innovation Management in

Agribusiness (Prof. Dr. Stefanie Bröring)

Bonn University

Analyst (Strategy Consulting)

Deloitte Tax \& Consulting Luxembourg

Tutor for Intermediate Macroeconomics

Chair for Macroeconomics and Money (Prof. Dr. Claudia Buch)

Tübingen University

Intern (International Trade \& Business Development)

German-Brazilian Chamber of Commerce

Rio de Janeiro, Brazil 


\section{E C L A R A T I O N S}

1. I, hereby, declare that this Ph.D. dissertation has not been presented to any other examining body either in its present or a similar form.

Furthermore, I also affirm that I have not applied for a Ph.D. at any other higher school of education.

Göttingen,

(Signature)

(Name in block capitals)

2. I, hereby, solemnly declare that this dissertation was undertaken independently and without any unauthorised aid.

Göttingen,

(Signature)

(Name in block capitals) 